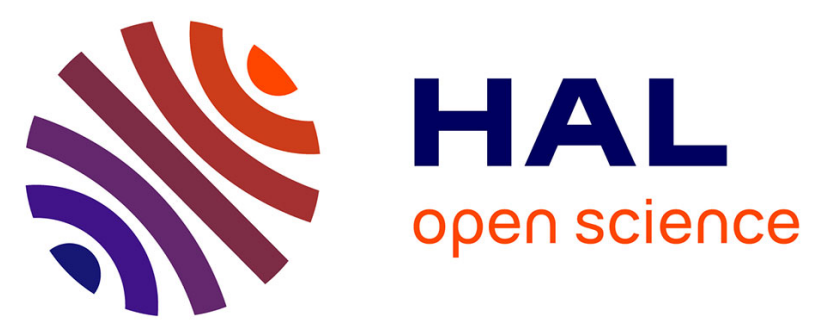

\title{
A study on the use of a metadata schema for characterizing school education STEM lessons plans by STEM teachers
}

Demetrios G. Sampson, Eleftheria Tsourlidaki, Nils Faltin, Panagiotis Zervas, Sofoklis Sotiriou, Yiwei Cao

\section{To cite this version:}

Demetrios G. Sampson, Eleftheria Tsourlidaki, Nils Faltin, Panagiotis Zervas, Sofoklis Sotiriou, et al.. A study on the use of a metadata schema for characterizing school education STEM lessons plans by STEM teachers. [Research Report] Go-Lab Project. 2016, pp.1-17. hal-01275021

\section{HAL Id: hal-01275021 \\ https://telearn.archives-ouvertes.fr/hal-01275021}

Submitted on 16 Feb 2016

HAL is a multi-disciplinary open access archive for the deposit and dissemination of scientific research documents, whether they are published or not. The documents may come from teaching and research institutions in France or abroad, or from public or private research centers.
L'archive ouverte pluridisciplinaire HAL, est destinée au dépôt et à la diffusion de documents scientifiques de niveau recherche, publiés ou non, émanant des établissements d'enseignement et de recherche français ou étrangers, des laboratoires publics ou privés. 


\section{Go-Lab}

Global Online Science Labs for Inquiry Learning at School

Collaborative Project in European Union's Seventh Framework Programme

Grant Agreement no. 317601

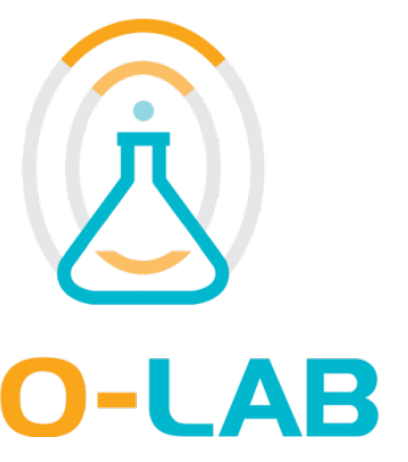

Deliverable D7.3

\section{Report on Implementation Activities \\ Phase-A}

Editor/Main Author: Georgios Mavromanolakis

Date: $\quad 31$ January 2015

Dissemination Level: Public

Status/Version: $\quad$ Final

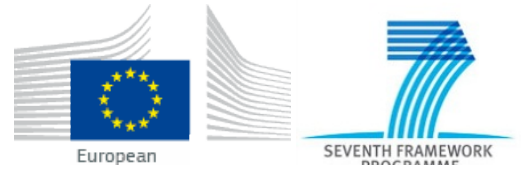

(C) 2015 Go-Lab Consortium 


\section{The Go-Lab Consortium}

\begin{tabular}{|c|c|c|c|}
\hline $\begin{array}{l}\text { Beneficiary } \\
\text { Number }\end{array}$ & Beneficiary name & $\begin{array}{l}\text { Beneficiary } \\
\text { short name }\end{array}$ & Country \\
\hline 1 & University Twente & UT & The Netherlands \\
\hline 2 & Ellinogermaniki Agogi Scholi Panagea Savva AE & EA & Greece \\
\hline 3 & École Polytechnique Fédérale de Lausanne & EPFL & Switzerland \\
\hline 4 & EUN Partnership AISBL & EUN & Belgium \\
\hline 5 & IMC AG & IMC & Germany \\
\hline 7 & Universidad Nacional de Educación a Distancia & UNED & Spain \\
\hline 8 & University of Leicester & ULEIC & United Kingdom \\
\hline 9 & University of Cyprus & UCY & Cyprus \\
\hline 10 & Universität Duisburg-Essen & UDE & Germany \\
\hline 11 & Centre for Research and Technology Hellas & CERTH & Greece \\
\hline 12 & Universidad de la Iglesia de Deusto & UDEUSTO & Spain \\
\hline 13 & $\begin{array}{l}\text { Fachhochschule Kärnten - Gemeinnützige } \\
\text { Privatstiftung }\end{array}$ & CUAS & Austria \\
\hline 14 & Tartu Ulikool & UTE & Estonia \\
\hline 15 & European Organization for Nuclear Research & CERN & Switzerland \\
\hline 16 & European Space Agency & ESA & France \\
\hline 17 & University of Glamorgan & UoG & United Kingdom \\
\hline 18 & $\begin{array}{l}\text { Institute of Accelerating Systems and } \\
\text { Applications }\end{array}$ & IASA & Greece \\
\hline 19 & Núcleo Interactivo de Astronomia & NUCLIO & Portugal \\
\hline
\end{tabular}




\section{Contributors}

\begin{tabular}{|l|l|l|}
\hline Name & Institution & Institution \\
\hline Georgios Mavromanolakis & EA & $\begin{array}{l}\text { Work Package 7 Leader, } \\
\text { National Coordinator in Greece, Romania, Bulgaria }\end{array}$ \\
\hline Evita Tasiopoulou & EUN & National Coordinator in Belgium, Italy, Poland \\
\hline Amir Mujkanovic & CUAS & National Coordinator in Austria \\
\hline Adam Giemza & UDE & National Coordinator in Germany \\
\hline Rosa Doran & NUCLIO & National Coordinator in Portugal \\
\hline Olga Dziabenko & UDEUSTO & National Coordinator in Spain \\
\hline Angelos Alexopoulos & CERN & National Coordinator in Switzerland \\
\hline Henny Leemkuil & UTE & National Coordinator in Netherlands \\
\hline Fraser Lewis & UOG & National Coordinator in UK \\
\hline
\end{tabular}

\section{Legal notices}

The information in this document is subject to change without notice.

The Members of the Go-Lab Consortium make no warranty of any kind with regard to this document, including, but not limited to, the implied warranties of merchantability and fitness for a particular purpose. The Members of the Go-Lab Consortium shall not be held liable for errors contained herein or direct, indirect, special, incidental or consequential damages in connection with the furnishing, performance, or use of this material.

The information and views set out in this deliverable are those of the author(s) and do not necessarily reflect the official opinion of the European Union. Neither the European Union institutions and bodies nor any person acting on their behalf may be held responsible for the use which may be made of the information contained therein. 


\section{Executive Summary}

Implementation Phase-A covered the period from project month 16 to month 21, which corresponds to 1 Feb 2014 - 31 Jul 2014. During that 6-month period partners organized and conducted 35 implementation activities around the host countries. Of which, 17 were activities with students (with 560 participants) and 18 training of teachers (with 380 participants). In total 381 secondary schools were involved in these activities (344 schools in teacher trainings and 37 in in-classroom activities with students). The full list of activity reports is included in the document.

The partners' focus for Phase-A was primary on offering and conducting comprehensive training for teachers covering the pedagogical and technical aspects of the Go-Lab approach. In this way they laid the foundations for successful next larger scale implementation phases with newer releases of the system (with updated and enriched repository of labs and authoring environment). The numbers reported herein are well exceeding the target set in Description of Work, i.e. implementation in 100 schools, and were necessary to be accommodated in order to satisfy the overwhelming interest and demand by schools to participate in the project. In Phase$A$, and in the majority of the reported events, activities involved the use of online labs standalone. In some cases there were implementations of existing or already developed Inquiry Learning Spaces with minimum authoring by teachers. The online labs that partners demonstrated and introduced to schools were from all three categories, simulations/virtual labs, datasets and remote labs. The activities were linked to various science curriculum domains and in particular to Physics, Astronomy, Technology, Biology, Ecology, Maths, and Chemistry. The grand majority is on Physics and Astronomy, a fact explained by the expertise and experience of the partners involved, and the online labs available in the repository at the time. The national coordinators and partners that organised or conducted these activities and closely interacted with the teachers and schools identified certain areas of concern or expectations of improvement that they expressed/recommended to be taken into account for the next implementation phase. The next implementation Phase-B runs in the 9-month period from month 25, 1 Nov 2014 - 31 Jul 2014. During this phase the pilot schools will use the system more extensively and at 3 levels, namely, use the Go-Lab repository of labs for searching; implement existing Inquiry Learning Spaces developed by the project teams; develop new or adapt existing Inquiry Learning Spaces. 


\section{Table of Contents}

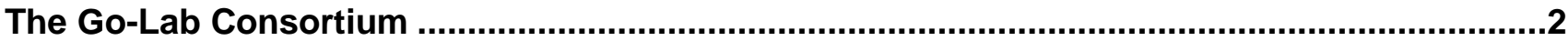

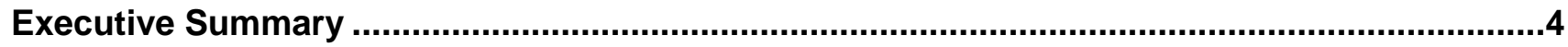

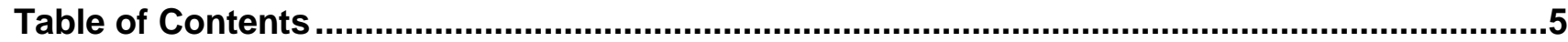

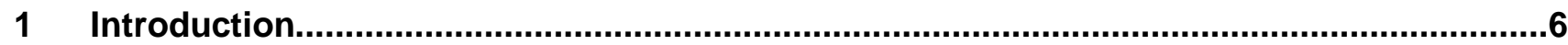

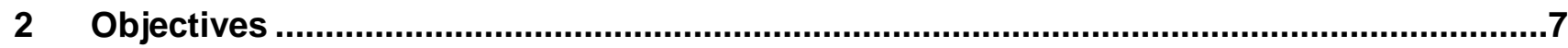

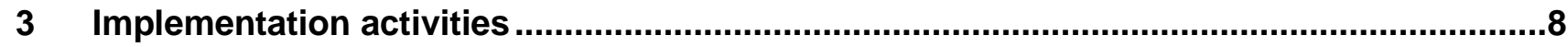

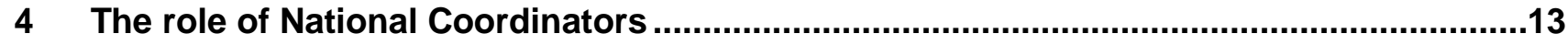

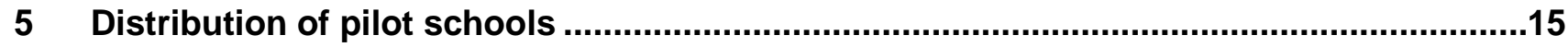

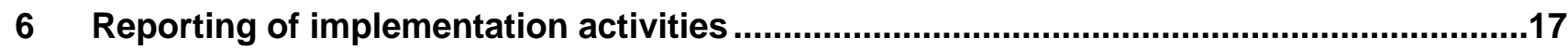

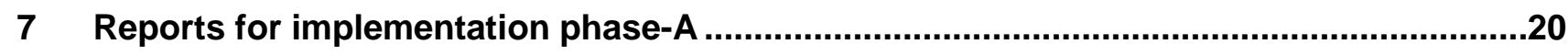

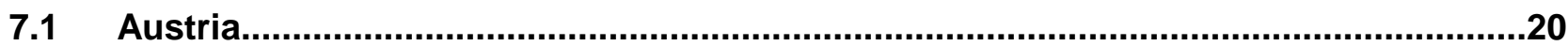

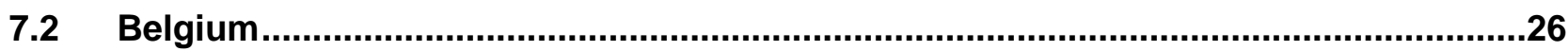

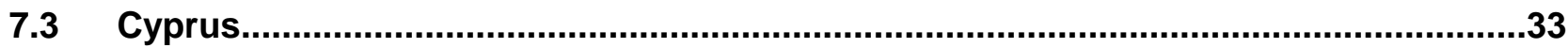

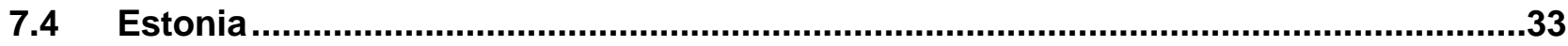

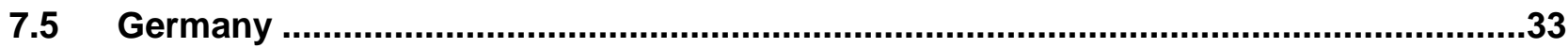

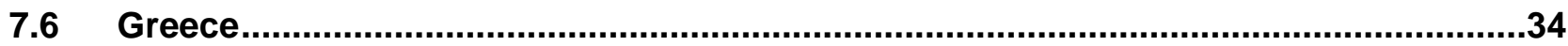

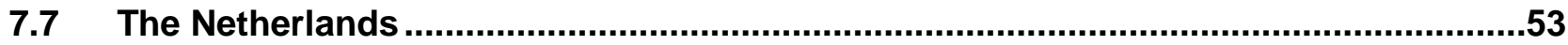

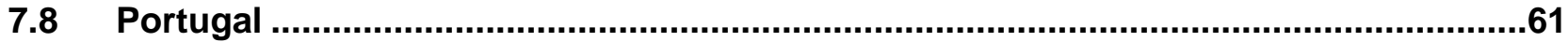

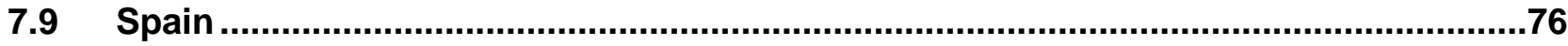

7.10 UK

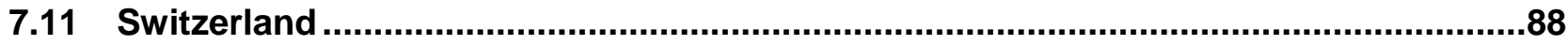

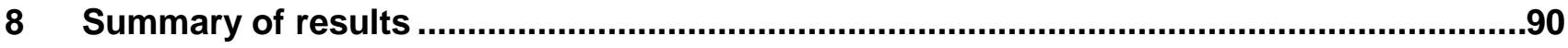

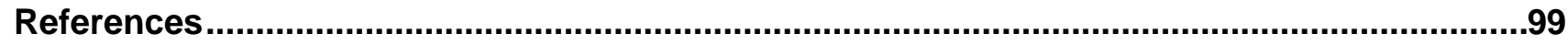

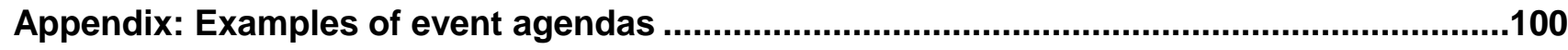




\section{Introduction}

Europe needs its youth to be skilful in and enthusiastic for science and also regard it as potential future career field in order to guarantee innovation, competiveness and prosperity. To ensure this, large scale initiatives are needed that engage students in interesting and motivating science experiences. To achieve this, the Go-Lab project's approach is to offer to teachers and their students a well organised federation of remote laboratories, virtual experiments, and datasets (all together referred to as "online labs") along with supporting, easy to access, lightweight end-user interfaces and frameworks that facilitate the use and adoption of them in the classroom practice and create an out of the ordinary engaging educational experience. Furthermore, teachers will be supported and guided to develop, implement and share their educational scenarios and build a wider community of practitioners that promotes the best practices across Europe and beyond.

The goal of the project is to implement the aforementioned approach at large scale in Europe, namely at 1000 schools, in 3 pilot phases, in the 15 participating countries of the consortium (the Netherlands, Greece, Bulgaria, Romania, Belgium, Poland, Italy, Cyprus, Germany, Spain, Austria, Estonia, Switzerland, UK, and Portugal).

The document herein first describes the main elements of the implementation plan that give the methodological and practical guidelines of actions to partners to be followed in order to realize this goal in the course of the project. Then it focuses on the implementation activities reported for the Phase-A, which covers the six-month period from 1 Feb 2014 to 31 Jul 2014. It concludes with the summary of results.

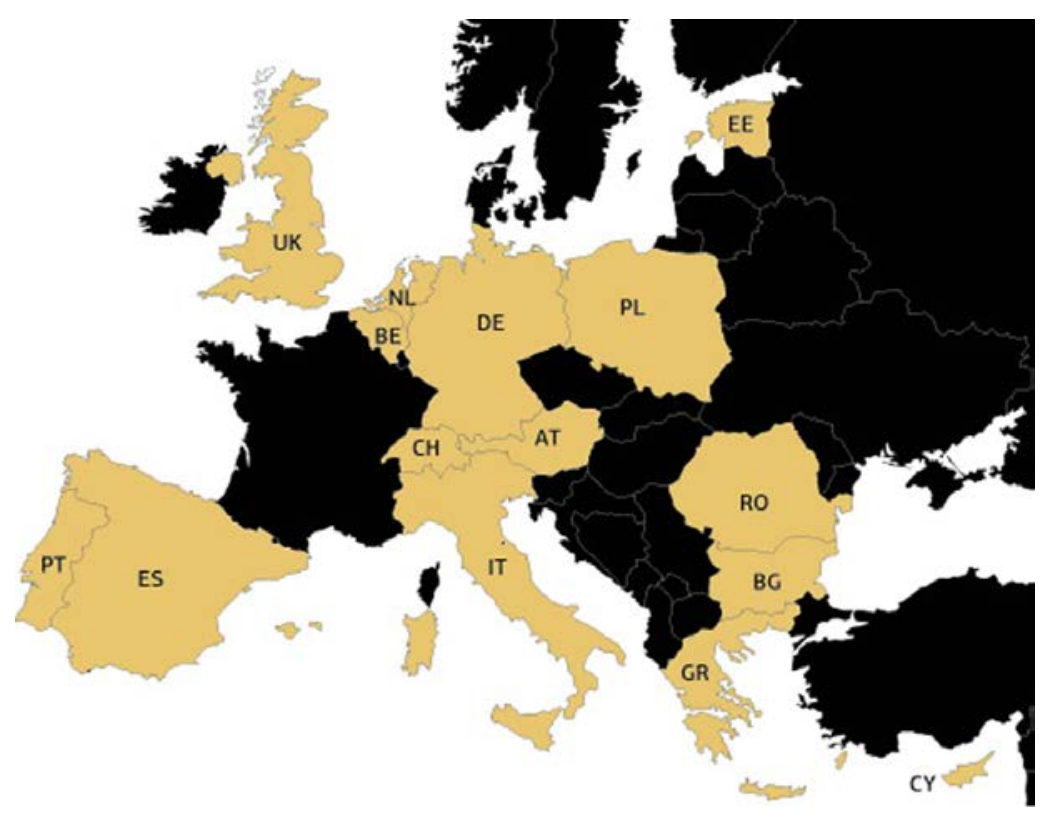

Figure 1. The 15 European countries where the Go-Lab project will be implemented 


\section{Objectives}

The aim of the Work Package 7 is to implement the Go-Lab pedagogical approach and the related inquiry classroom scenarios, developed in Work Package 1, at large scale in Europe. The project will be implemented in 3 phases at 1000 schools in the 15 participating countries, the Netherlands, Greece, Bulgaria, Romania, Belgium, Poland, Italy, Cyprus, Germany, Spain, Austria, Estonia, Switzerland, UK, and Portugal. This is a challenging task that can only be realized with a well-planned, coordinated and collaborative effort along clear and systematic guidelines detailed in an implementation plan. The Implementation Plan developed for this task is laid out in the coming sections and documents the following set of objectives which are organized in four interconnected major elements:

- [Implementation activities]

To describe and propose a methodology for the involvement of the pilot schools in the GoLab project. General guidelines and practical examples of implementation activities to illustrate the process of recruiting, building, supporting and sustaining a community of teachers are given.

- $\quad$ Key partner/coordinator per country]

To define the role and the duties of the National Coordinators underlining their importance in the collaborative effort needed to manage the implementation activity.

- [Number of schools per country per implementation phase]

To distribute the number of the pilot sites in a balanced way across the 15 participating countries.

- [Reporting of activities]

To describe the reporting procedure that should be followed in order to document and monitor the implementation progress throughout the life of the project.

The scope of these objectives or procedures may not change over the lifetime of the project, however additional and complementary items (e.g. contingency plan) might be added if necessary reflecting the experience gained as the project advances. 


\section{Implementation activities}

The implementation of the Go-Lab project takes place in 3 phases covering 3 consecutive school years (see Fig.2). The pilot schools are recruited from countries where partners are based (the Netherlands, Greece, Belgium, Cyprus, Germany, Spain, Austria, Estonia, Switzerland, UK, and Portugal) and also from Bulgaria, Romania, Poland and Italy. In Phase-A more than 100 pilot schools were recruited [6]. In Phase-B 400 more schools will be added in the network of pilot sites [7]. In Phase-C 500 more schools from the participating countries will join the network. Phase-A starts in M16 (Feb.2014) and lasts 6 months, Phase-B starts in M25 (Nov.2014) and lasts 9 months and Phase-C starts in M37 (Nov.2015) and lasts 9 months. Before and during each phase various in-school implementation and community building/support activities are planned to take place in each country organised by the partners of the consortium in order to attract and engage science teachers in the Go-Lab project. (The community building actions are the focus of Work Package 6 , further details can be found in reference [3] Go-Lab Deliverable 6.1 "Specifications of Participatory Activities").

\section{Tasks and Deliverables}

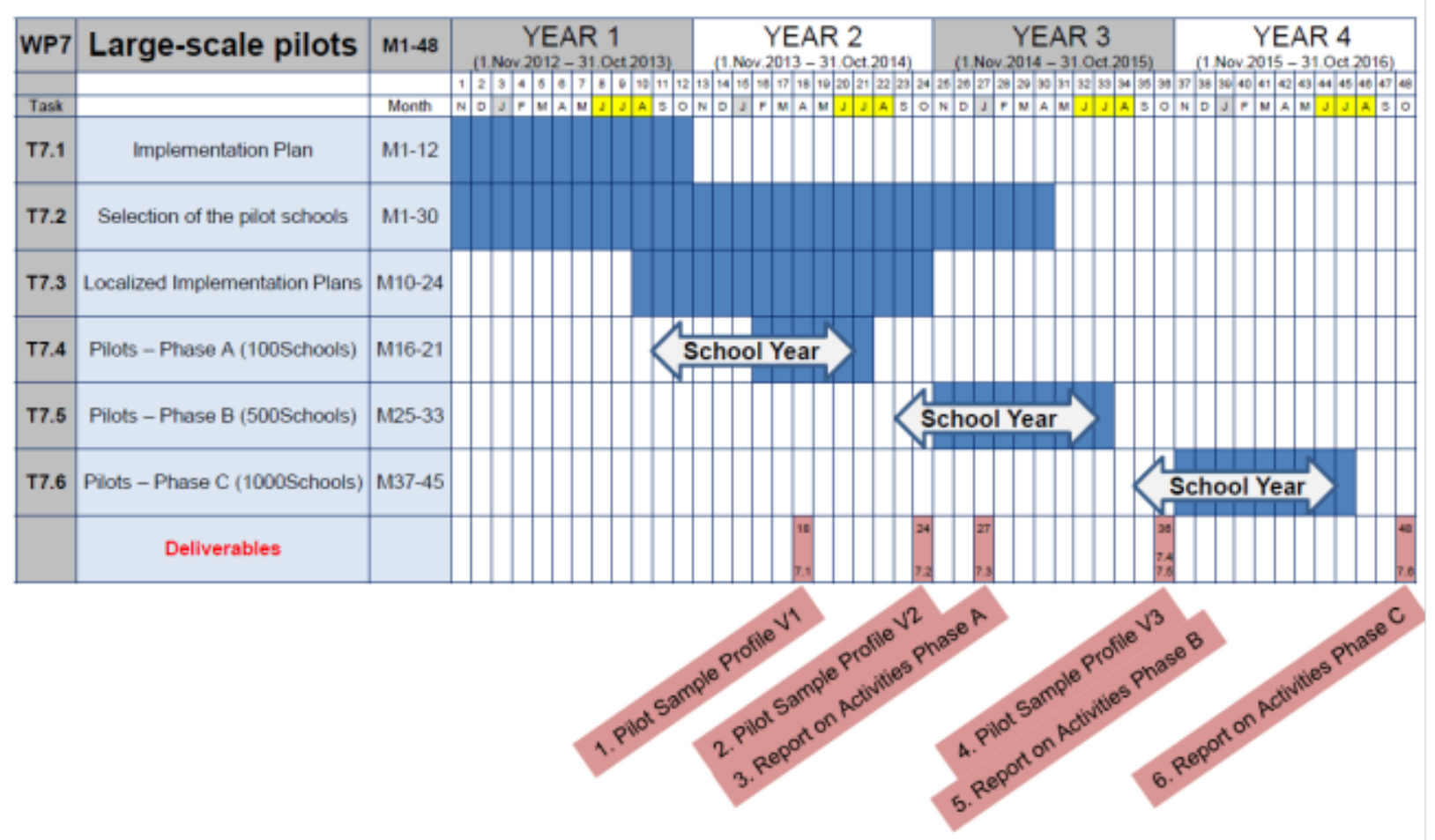

G.Mavromanolakis GoLab Kick-off Meeting, 19-20 Nov 2012, Univ. of Twente, Netherlands

Figure 2. Time plan of tasks and deliverables of Work Package 7 - "Large-scale pilots"

In general, an implementation activity intends to bring into the classroom practice the use of online labs and related resources in an innovative, user friendly and engaging way so that both teachers and students have a stimulating experience in science education. Series of support activities (such as presentation seminars and training workshops) are organised for teachers, in 
order to get familiarized with the relevant technology, gain confidence and be able to adopt and also adapt the use of online labs in their everyday school practice.

All in-school activities with students and preparation/support actions such as training for teachers, both referred in the following as implementation activities, events or actions, are centrally coordinated by the Work Package 7 Leader, but also managed locally by one partner in each of the pilot countries who acts as the National Coordinator and is responsible for the local management and localization of the project resources and activities. The role and duties of the National Coordinators are discussed further and in detail in section 4. At this point it should be noted that the Go-Lab consortium is composed of partners with diverse background and there are countries that are represented by a partner or partners with limited or no experience in education. In the spirit of a collaborative and shared effort those partners are given every feasible support and guidance by more experienced partners.

Of particular concern is how and from where science teachers can be approached initially and then be engaged in implementing Go-Lab activities in their schools. This concern was expressed vividly by both more and less experienced partners during consortium and online meetings illustrating the challenge that the project faces in reaching 1000 schools across 15 countries. With respect to methods of approach recommended, these were briefly presented during the meeting, see reference [2]. They are further elaborated below.

\section{Methods of approach}

- Top-down

In this approach partners use official channels of communication to approach and invite teachers/schools to Go-Lab's activities (introductory seminars, training workshops etc). In other words, the National Coordinator or local partner in charge contacts the district's school counsellor or regional bureau of education or other equivalent authority and informs them about the Go-Lab project. An introductory-informational event is arranged and teachers from the area are invited officially to attend. An example agenda of such an event is shown in Appendix. The teachers interested further in applying Go-Lab in their science classroom are given further guidance and support material with educational content (i.e. classroom scenarios using online labs) to start with. If needed additional events to provide training and practicing are organised (see example agendas for a short or a day long workshop in Appendix).

\section{- Bottom-up}

Partners organize informational events and visionary workshops, as indicated in Deliverable 6.1 "Specifications of Participatory Activities", inviting science teachers from schools in their local area. In addition several Go-Lab partners have collaborated within the framework of European projects on education with pioneering and innovative science teachers. In this case partners approach directly these already known teachers, and possibly through them their network of colleagues, informing them about Go-Lab.

Also within this approach the National Coordinator or partner in each country contacts science teacher societies and national professional unions, participates in their conferences or annual meetings by giving a talk or seminar or arranging workshops to be held during these events to inform and attract teachers in Go-Lab.

Partners that are being or operating within institutions of higher education can approach faculty members in the Dept. of Education in their own or local university who are involved in research on science education. Through them can be approached teachers and schools with whom they are currently conducting field research or have collaborated in the past. 
- Educational contests for teachers and students

Partners organise in collaboration with educational authorities or science related societies/centers/museums contests, at regional or national or even international level, that promote the use of online labs in the classroom. An example of such a contest could be on the development of educational scenarios or activities using online labs along a general science theme or a more specific one (e.g. in connection with celebrations of a key event such as a scientific discovery or the birth of a renowned scientist). The teacher who designs and implements the best activity will be awarded a prize, e.g. funding support to participate in a conference or summer school for professional development. These contests will be organised and implemented during the school years in line with the pilot Phases A, B and C. It is suggested that at least one contest per country per implementation year will be held.

These methods have been followed in the past successfully by Go-Lab partners in various countries. However they may not prove efficient and adequate in certain countries or regions. Country specific implementation plans have been developed in collaboration with the National Coordinators to reflect local circumstances and practices. They have been documented in the internal deliverable G7.2 "Localized Implementation Plans" due in M12.

Further potential points of interaction with science teachers are also listed below. These are the established educational programmes run by Go-Lab partners and are attracting science teachers at international level. Introductory seminars and training workshops on Go-Lab approach and platform can be integrated within the framework of these programmes. Participant teachers from the various countries who express interest in Go-Lab will then be delegated to the corresponding National Coordinator for further guidance, support and inclusion in the community of practice in their country. In this way a crucial obstacle of implementation being the language and cultural barriers across the different countries will be overcome.

\section{Points of interaction - Established educational programmes}

\section{CERN High School Teachers Programme}

(http://teachers.web.cern.ch/teachers/)

The programme consists of a 3-week stage, taking place every year since 1998 at CERN during the month of July. The stage is open to Physics High School Teachers from all CERN member and observer States, as well as from other countries subject to funding availability.

\section{(CERN is a partner of Go-Lab)}

\section{The European Space Education Resource Office (ESERO)}

(http://www.esa.int/Education/Teachers_Corner/European_Space_Education_Resource_Office) The European Space Education Resource Office (ESERO) project is ESA's primary way of supporting the educational community. Established in various Member States, each ESERO aims to support the specific educational needs of the Member State and their Education Community. Teachers are able to access specially developed materials that are tailored to their needs and to attend dedicated training workshops. Lesson plans, fact sheets and comprehensive education kits are also available online. The ESERO project aims to enhance young people's literacy in STEM subjects and associated applications. It uses space related themes and the genuine fascination for spaceflight, to encourage pupils to consider careers in these fields and in the space domain in particular. Each ESERO implements an annual series of primary \& secondary teacher training sessions. These are usually in collaboration with national 
partners already active in STEM education. They use and disseminate existing ESA/ESERO education materials and, if appropriate, develop specific resources tailored to the needs of their national education community. ESEROs also organises national ESERO teacher conferences for secondary and primary education. (ESEROs are located in these Go-Lab countries: the Netherlands, Belgium, UK).

(ESA is a partner of Go-Lab)

\section{Annual ESA Summer Teacher Workshop}

(http://www.esa.int/Education/Teachers_Corner/Annual_ESA_Summer_Teacher_Workshop)

Every summer, ESA's Education Office welcomes around 40 teachers from across Europe to ESA's European Space Research and Technology Centre in the Netherlands. Over the course of four days, in the heart of ESA's largest establishment, the teachers engage in a number of workshops about how space can be used as a context for teaching many subjects. Space experts, both from within ESA and outside, guide the teachers through mainly hands-on practical workshop sessions. The workshops are fully sponsored and applications are welcomed from all ESA Member States.

(ESA is a partner of Go-Lab)

\section{Galileo Teacher Training Programme (GTTP)}

(http://www.galileoteachers.org)

Initiated during 2009's International Year of Astronomy, and named after the famous 17th century Italian astronomer and physicist, the GTTP now continues to train teachers across Europe. The emphasis is placed upon introducing science teachers to the resources that can be used to teach astronomy and astrophysics. The programme aims to help teachers inspire young people to consider science careers. Workshops take place at various sites throughout Europe. NUCLIO has long experience in organizing GTTP supported events.

(NUCLIO is a partner of Go-Lab)

\section{COMENIUS and GRUNDTVIG in-service training for school and adult educators (now followed up by Erasmus+ Programme)}

The Lifelong Learning Programme for European co-operation in the field of education and training offers grants to teachers and teacher educators to participate in training courses, seminars and conferences held in Europe and help them upgrade their professional skills in the field of education. Partners of the Go-Lab consortium (e.g. EA, EUN, NUCLIO) have long experience in organising international schools and workshops on professional development of science teachers and educators. EA already took the initiative to organise the first Go-Lab related International Summer School to be held in Greece in summer 2013 with its participants supported by the Comenius grant scheme. It is envisaged to be a great opportunity of showcasing the project's approach and framework to teachers from various countries. It is further proposed that similar summer schools to be held in 2014, 2015 and 2016 after the end of the pilot phases A, B and C respectively. These events will follow the project's progress, get together less and more experienced teachers who can develop and share best practices and reflect on their experience and concerns.

(EA and EUN are partners of Go-Lab)

Additionally, as already mentioned the implementation effort is supported through effective community building and support of the implementation communities in each country by the work performed in Work Package 6 (for guidelines, description and schedule of visionary and practice reflection workshops to be organised in each country see Deliverable 6.1, ref.[3] and [4]). The 
figure below depicts the mechanism of recruiting and engaging teachers in Go-Lab and the interconnection between Work Packages 6 and 7.

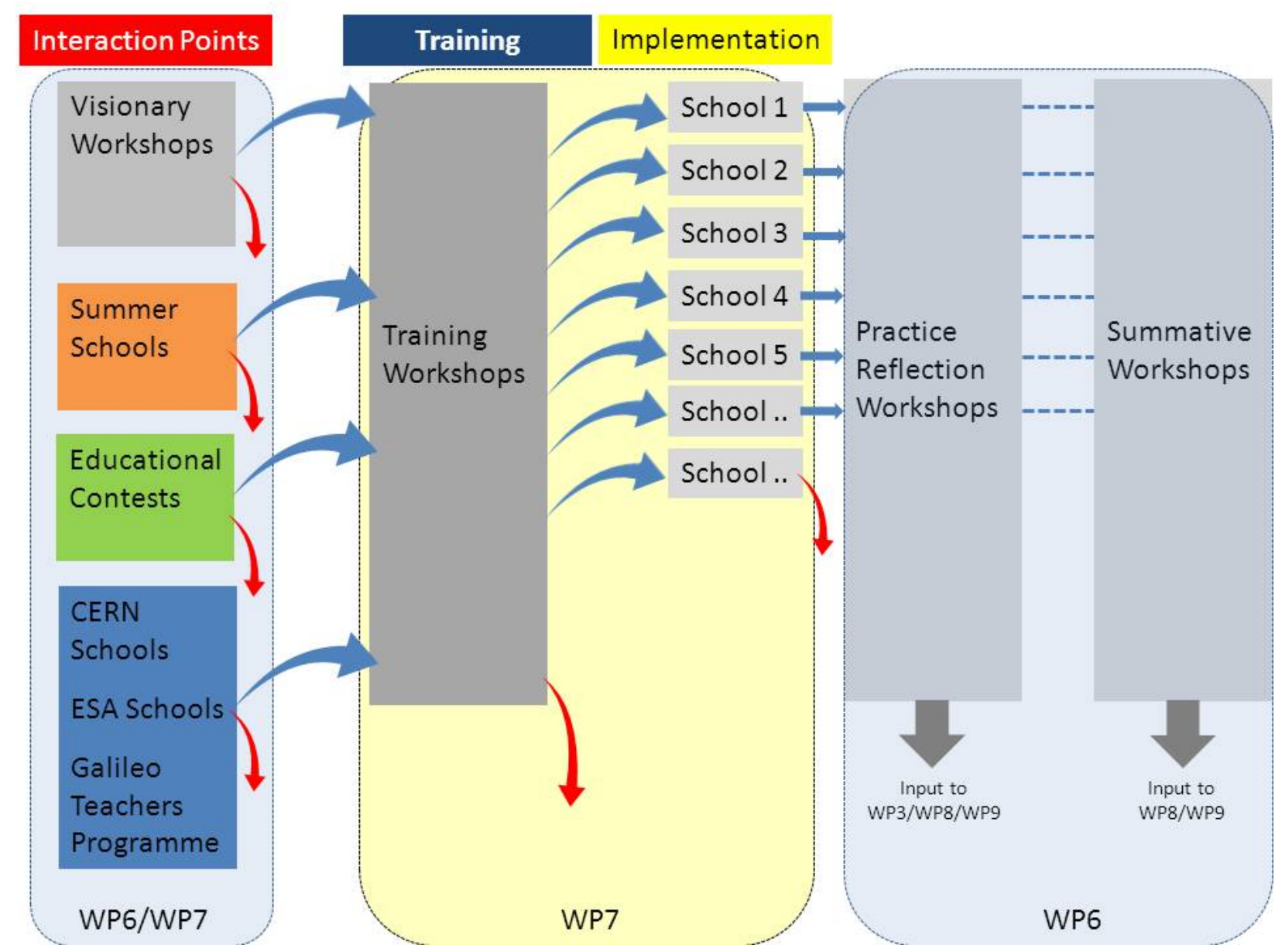

Figure 3. Mechanism of recruiting, engaging and sustaining a community of practitioner teachers in Go-Lab

The success of the implementation is strongly depending not only on following the guidelines laid out in this implementation plan but also on the outcome of tasks in other work packages that should be delivered on time and characterized by sufficient quality and functionality. In brief a successful implementation requires having at hand during the course of the project to offer teachers an overall educational approach and functional environment characterized by the following qualities:

- it satisfies users' real educational and pedagogical needs,

- it is attractive,

- it is user friendly,

- it is easily available and properly supported. 


\section{The role of National Coordinators}

All implementation activities are centrally coordinated by the Work Package 7 Leader, but also managed locally by one partner in each of the pilot countries who acts as the National Coordinator. The National Coordinator is responsible for the local management and localization of the project resources and activities regarding the selection and evaluation of the pilot sites, the implementation activities and supporting actions. Initially the planning and coordination of each implementation activity will be performed and supported centrally (by the partners who have extensive experience in the field like EA and EUN) but during the implementation phases the activity will also be managed locally by the National Coordinator in each of the pilot countries who will act as the key national contact and who will be responsible for the local organization and localization of the project's implementation plan. In this context the role of the National Coordinators is considered as one of the key factors for the successful implementation of the Go-Lab's pedagogical approach in their country and for driving change in the school communities by first diagnosing and understanding the context and players and then trying to "convince" them. The pilot schools in each participating country will serve as working models and demonstrators, where the project's activities will be realized.

A series of support activities (such as presentation seminars and training workshops) are organised, in order for the users to get familiarized with the relevant technology and to enable the adaptation of the use of the online labs in the everyday school practice. In the framework of the workshops the users will be informed about the project's approach, as their participation to the project will be systematically monitored and assessed. Follow-up workshops, so-called practice reflection workshops, will be organised by the National Coordinators for each of the participating countries, according to a common generic procedure developed within the Work Package 6, which however will allow for flexibility to adapt to a variety of local circumstances.

The selection of the first group of schools started in the second half of the first project year, based on National Coordinators' accumulating experiences from the interaction with the school communities and taking into account any expressed school interest provoked by local project publicity and dissemination actions. In the whole duration of the project, 1000 schools in total will participate as pilot sites in the project's activities, distributed in a balanced way across the participating countries and the different school contexts. The National Coordinators are responsible for the selection of the pilot sites in their countries taking into consideration the local conditions while they will also follow a common set of selection criteria.

All evaluation activities will also be centrally designed and coordinated, but implemented in close collaboration with the National Coordinators responsible for each country's pilot sites. If necessary, after the selection of each pilot site and before its involvement in evaluated implementation activities, baseline data and information about it will be collected by the National Coordinators. This will produce a consistent set of 'known parameters' about the pilot sites, which will form the reference basis for all future analysis and comparisons.

The list of National Coordinators, as agreed and documented in the "Description of Work", is presented in the following table (see also reference [1]). It contains the code names of the institutions that will resume the role and the name of the person in charge. 


\begin{tabular}{|lll|}
\hline Country & $\begin{array}{l}\text { National } \\
\text { Coordinator }\end{array}$ & \\
\hline Netherlands & UT & Henny Leemkuil \\
\hline Cyprus & UCY & Zacharias Zacharia \\
\hline Germany & UDE & Adam Giemza \\
\hline Spain & UD & Olga Dziabenko \\
\hline Austria & CUAS & Amir Mujkanovic \\
\hline Estonia & UTE & Urmas Heinaste \\
\hline Switzerland & CERN & Angelos Alexopoulos \\
\hline $\begin{array}{l}\text { UK } \\
\text { Portugal }\end{array}$ & UOG & Fraser Lewis \\
\hline $\begin{array}{l}\text { Greece } \\
\text { Bulgaria } \\
\text { Romania }\end{array}$ & EA & Rosa Doran \\
\hline $\begin{array}{l}\text { Belgium } \\
\text { Poland } \\
\text { Italy }\end{array}$ & EUN & Georgios Mavromanolakis \\
\hline
\end{tabular}

Table 1. The National Coordinators for the Implementation and Validation Activities 


\section{Distribution of pilot schools}

The implementation of the Go-Lab project will take place in 3 phases covering 3 consecutive school years. In Phase-A at least 100 pilot schools have to be recruited from the 15 participating countries. In Phase-B 400 more schools will be included in the network of pilot sites. In Phase-C 500 more schools will join the network.

An algorithm has been developed to distribute the total number of pilot schools in a balanced way across the countries participating in the Go-Lab project. It takes into account the following considerations:

- a minimum threshold number of 15 schools in each of the 11 countries should be recruited by the partners in order to have a representative sample for implementation and evaluation

- the number of pilot sites per country should scale with the partners' total person-month effort contribution in Work Packages 6 and 7

- $10 \%$ person-month effort allowance is taken into account for the partners that are leading Work Packages 6 and 7. The corresponding person-month effort will be attributed in the overall coordination of the implementation and community building and support actions

- to recruit pilot schools in the 4 countries (Bulgaria, Romania, Poland and Italy) that they are not represented by partners in the Go-Lab consortium a double person-month effort per recruited school is assumed

The outcome distribution accommodating these considerations is shown in table 2. For certain countries that are represented by partners that have an international status rather a national one e.g. EUN in Belgium, CERN in Switzerland, the number of schools quoted should be interpreted as target recruits coming from European countries in general and not only from the partner's host country.

The distribution shown in the table below was presented and discussed during the Go-Lab kickoff meeting and the "Communities Cluster" (see reference [2] and [4]). It is agreed to set the corresponding target numbers and is communicated regularly to the National Coordinators and the consortium at online and onsite meetings. 


\begin{tabular}{|lcccc|}
\hline Country & $\begin{array}{l}\text { Target } \\
\text { Nof } \\
\text { Schools }\end{array}$ & $\begin{array}{l}\text { Pilots - } \\
\text { Phase A }\end{array}$ & $\begin{array}{l}\text { Pilots - } \\
\text { Phase B }\end{array}$ & $\begin{array}{c}\text { Pilots - } \\
\text { Phase C }\end{array}$ \\
\hline Netherlands & 40 & 4 & 16 & 20 \\
\hline Cyprus & 40 & 4 & 16 & 20 \\
\hline Germany & 100 & 10 & 40 & 50 \\
\hline Spain & 60 & 6 & 24 & 30 \\
\hline Austria & 100 & 10 & 40 & 50 \\
\hline Estonia & 40 & 4 & 16 & 20 \\
\hline Switzerland & 70 & 7 & 28 & 35 \\
\hline $\begin{array}{l}\text { UK } \\
\text { Portugal }\end{array}$ & 100 & 10 & 40 & 50 \\
\hline $\begin{array}{l}\text { Greece } \\
\text { Bulgaria }\end{array}$ & 220 & 22 & 88 & 110 \\
Romania & & & & \\
\hline $\begin{array}{l}\text { Belgium } \\
\text { Poland }\end{array}$ & 160 & 16 & 64 & 80 \\
Italy & 1000 & 100 & $\mathbf{4 0 0}$ & $\mathbf{5 0 0}$ \\
\hline total & & & & \\
\hline
\end{tabular}

Table 2. Distribution of the pilot schools across the participating countries for the three implementation phases 


\section{Reporting of implementation activities}

An integral part of the implementation plan is the reporting actions and procedures that should accompany the Go-Lab's three large-scale implementation phases across the 15 countries. Proper and up-to-date reporting is vital to monitor the project's implementation development, to have a smooth bookkeeping of activities per country, to determine overall progress and identify countries or regions where this may not be at satisfactory level, and to ensure the implementation quality. The reports form the basis of the project's official deliverables, to be submitted at the end of each implementation phase, as is the case with this deliverable D7.3 Report on Implementation Activities - Phase A due in M27, and similarly with D7.5 Report on Implementation Activities - Phase B due in M36 and D7.6 Report on Implementation Activities Phase $\mathrm{C}$ due in M48.

According to the plan for each implementation event or series of activities the partner or partners involved is expected to produce a report. This should be sent to the National Coordinator or directly to the Work Package 7 Leader and uploaded to a repository/common user space in graasp. Reports document basic information about the activity such as date/period held, location, number of participants, target group and type of activity along with a brief and comprehensive description of the implementation activities, online labs used/demonstrated and learning outcomes reached or expected. Also, any material in printed or electronic format that is related to the implementation activity is also be attached to the report as well (e.g. dissemination material handed to participants, educational material produced specifically for the activity, photos or videos taken during the event, etc). The tables that follow show two forms/templates proposed and agreed for reporting Training Activities/Events with teachers and Implementation Activities with students respectively.

The implementation activity reports compose a key part of the overall public image of the project. Material included in them will also be used in dissemination actions and documents. Furthermore, the information contained in the reports will be assessed and integrated in the validation and evaluation work, which is the focus of the Work Package 8 , in order to develop a concrete picture of the integration of Go-Lab in educational activities and identify the impact level in terms of the effectiveness and efficiency to the teacher communities.

The reporting of the implementation activities are periodically reviewed to measure progress and provide creative and constructive feedback to and from the National Coordinators and the partners involved in the organization and implementation of educational activities. The goals and scope of the reporting procedure will not change over the lifetime of the project, but specific improvements and revisions or complementary actions might be added over time if needed. 


\begin{tabular}{|c|c|}
\hline $\begin{array}{l}\text { G O - L A B } \\
\text { Event Code }\end{array}$ & $\begin{array}{l}{[L L X X-D D M M Y Y] \text { Please follow this format: }} \\
L L=2 \text { letter country code, } X X=\text { partner id, } D D M M Y Y=\text { date }\end{array}$ \\
\hline \multicolumn{2}{|l|}{ Title } \\
\hline $\begin{array}{r}\text { Country } \\
\text { City/Region }\end{array}$ & \\
\hline \multicolumn{2}{|l|}{ Working language } \\
\hline Start/End Date & Please use this format DD/MM/YYYY \\
\hline \multicolumn{2}{|l|}{$\begin{array}{l}\text { Organizing } \\
\text { Institute }\end{array}$} \\
\hline \multicolumn{2}{|l|}{$\begin{array}{r}\text { Coordinator name } \\
\text { and email }\end{array}$} \\
\hline Activity Form & [Workshop, Seminar, Conference, Summer School, in-school activity, etc] \\
\hline Activity Type & $\begin{array}{l}\text { [Local, National, International] } \\
\text { Local activities: Demonstration \& training in schools or in teachers training centers, workshops/seminars at } \\
\text { regional level, etc. } \\
\text { National activities: National Conferences and Workshops, or Contests for students and teachers, etc. }\end{array}$ \\
\hline $\begin{array}{l}\text { Total number of } \\
\text { teachers/schools }\end{array}$ & Provide the number, or an estimate, of participants. \\
\hline \multicolumn{2}{|l|}{$\begin{array}{l}\text { Implemented } \\
\text { online labs }\end{array}$} \\
\hline Brief description & $\begin{array}{l}\text { Write one or two paragraphs describing in brief the activity (subject, objectives, } \\
\text { target audience etc) }\end{array}$ \\
\hline $\begin{array}{l}\text { Learning } \\
\text { outcomes }\end{array}$ & $\begin{array}{l}\text { Give a short description of what participants are expected to have learned } \\
\text { (e.g. will be able to use online labs and IBSE methods, be able to use online } \\
\text { resources, repositories, tools, best practices etc) }\end{array}$ \\
\hline Website & (if applicable) The URL of the website that has been set up for this activity. \\
\hline $\begin{array}{l}\text { Photos or other } \\
\text { relevant material }\end{array}$ & $\begin{array}{l}\text { Select 3-4 good-quality photos or other relevant material (flyer, brochure, poster) } \\
\text { and attach them in this report }\end{array}$ \\
\hline Event agenda & $\begin{array}{l}\text { (if applicable) Please copy here the agenda of the event (program of activities, } \\
\text { etc.). }\end{array}$ \\
\hline
\end{tabular}

Table 3. Proposed template of Training Activity Report 


\begin{tabular}{|c|c|}
\hline $\begin{array}{r}\text { G O - L A B } \\
\text { Report Code }\end{array}$ & $\begin{array}{l}\text { [LLXX-DDMMYY] Please follow this format: } \\
L L=2 \text { letter country code, } X X=\text { partner id, } D D M M Y Y=\text { date }\end{array}$ \\
\hline \multicolumn{2}{|l|}{ Title } \\
\hline $\begin{array}{r}\text { Country } \\
\text { City/Region }\end{array}$ & \\
\hline \multicolumn{2}{|l|}{ Working language } \\
\hline Start/End Date & Please use this format DD/MM/YYYY \\
\hline \multicolumn{2}{|l|}{ Partners Involved } \\
\hline \multicolumn{2}{|l|}{$\begin{array}{r}\text { Coordinator name } \\
\text { and email }\end{array}$} \\
\hline \multicolumn{2}{|l|}{ School Profile } \\
\hline $\begin{array}{r}\text { Number and age } \\
\text { of students }\end{array}$ & $\begin{array}{l}\text { Provide the number, or an estimate, of participant students. Please also indicate } \\
\text { their age group }\end{array}$ \\
\hline $\begin{array}{r}\text { Activity } \\
\text { Description }\end{array}$ & $\begin{array}{l}\text { Write one or two paragraphs describing in brief the activity (mention subject e.g. } \\
\text { physics, biology, etc, objectives, target audience etc) }\end{array}$ \\
\hline \multicolumn{2}{|l|}{$\begin{array}{l}\text { Implemented } \\
\text { online labs }\end{array}$} \\
\hline $\begin{array}{l}\text { Learning } \\
\text { outcomes }\end{array}$ & $\begin{array}{l}\text { Give a short description of what participants are expected to have learned } \\
\text { in connection with the concepts of Big Ideas }\end{array}$ \\
\hline $\begin{array}{l}\text { Photos or other } \\
\text { relevant material }\end{array}$ & $\begin{array}{l}\text { Select 3-4 good-quality photos or other relevant material (brochure, poster) and } \\
\text { attach them in this report }\end{array}$ \\
\hline
\end{tabular}

Table 4. Proposed template of Implementation Activity Report 


\section{Reports for implementation phase-A}

\subsection{Austria}

CUAS conducted and coordinated the implementation activities in Austria listed in the following table. Two training activities for science teachers were organized, with 22 participants, where the Radioactivity and VISIR labs were introduced and practiced. In one occasion there was also a workshop for high-school students with 52 participants using the labs and related ILSs. The subject domains of these activities and labs focused on physics and technology.

\begin{tabular}{|l|l|l|l|l|}
\hline Date(s) & Type & Participants & Labs & Subject(s) \\
\hline 03/04/2014 & Training of teachers & $16(10)$ & Radioactivity, VISIR & Physics, Technology \\
\hline 03/04/2014 & Activity with students & $52(4)$ & Radioactivity, VISIR & Physics, Technology \\
\hline $07 / 07 / 2014$ & Training of teachers & $6(6)$ & Radioactivity & Physics \\
\hline
\end{tabular}

In the following the detailed reports from the activities are shown. 


\begin{tabular}{|c|c|}
\hline $\begin{array}{l}\text { G O - L A B } \\
\text { Event Code }\end{array}$ & AT13-030414 \\
\hline $\begin{array}{r}\text { Context: } \\
\text { standalone event } \\
\text { or combined with } \\
\text { other ws, online or } \\
\text { face to face }\end{array}$ & Combined with others; Face to face \\
\hline $\begin{array}{r}\text { Country } \\
\text { City/Region }\end{array}$ & Austria / Villach \\
\hline Working language & German and English \\
\hline Start/End Date & 03.04.2014 | 1 hours \\
\hline $\begin{array}{l}\text { Organizing } \\
\text { Institute }\end{array}$ & CUAS \\
\hline $\begin{array}{r}\text { Coordinator name } \\
\text { and email }\end{array}$ & $\begin{array}{l}\text { Amir Mujkanovic } \\
\text { A.Mujkanovic@FH-Kaernten.at }\end{array}$ \\
\hline $\begin{array}{l}\text { Total number of } \\
\text { teachers/schools }\end{array}$ & 16 teachers from 10 secondary schools \\
\hline Brief description & $\begin{array}{l}\text { The Go-Lab portal and the Website were presented and teachers were } \\
\text { encouraged to access it and spread the word to their colleagues. } \\
\text { Teachers were asked to use the Radioactivity or the VISIR ILS and } \\
\text { provide their feedback on the overall experience. Participates were } \\
\text { particularly asked to use the scratchpad and the hypothesis tool included } \\
\text { in the conclusion of the Radioactivity ILS. }\end{array}$ \\
\hline $\begin{array}{r}\text { Facilitators } \\
\text { Observations }\end{array}$ & $\begin{array}{l}\text { Teachers were engaged in the activities and the facilitators had the } \\
\text { impression that they were interested and enjoyed working with the ILSs. } \\
\text { They were impressed that they could explain the radioactivity to their } \\
\text { students by using an experimentation apparatus that is located in Australia } \\
\text { that is literally half way around the world from the actual user. They also } \\
\text { saw a real benefit of the visualization of the emitted radioactive rays. }\end{array}$ \\
\hline $\begin{array}{r}\text { Common themes } \\
\text { identified in the } \\
\text { case studies }\end{array}$ & \\
\hline $\begin{array}{r}\text { Examples illustrating } \\
\text { common themes }\end{array}$ & \\
\hline $\begin{array}{r}\text { Recommendations } \\
\text { made by } \\
\text { participants }\end{array}$ & $\begin{array}{l}\text { - One teacher was particularly interested if there are any ILSs available } \\
\text { that include experimentation related to Geography. } \\
\text { - } \quad \text { It would be useful to be able to export the notes made in the } \\
\text { scratchpad that is embedded in the conclusion phase } \\
\text { - ILSs in German are definitely needed } \\
\text { - } \quad \text { A better integration of ILSs into the particular curricula would be } \\
\text { helpful for teachers. }\end{array}$ \\
\hline
\end{tabular}




\begin{tabular}{|r|l|}
\hline Website & No website \\
\hline $\begin{array}{r}\text { Photos or other } \\
\text { relevant material }\end{array}$ & No pictures available \\
\hline Event agenda & $\begin{array}{l}\text { - Intro to Go-Lab Portal } \\
\text { - Individual usage of ILSs } \\
\text { - Reflection of the used ILSs } \\
\text { - Discussion }\end{array}$ \\
\hline
\end{tabular}




\begin{tabular}{|c|c|}
\hline $\begin{array}{r}\text { G O - L A B } \\
\text { Report Code }\end{array}$ & AT13-030414 \\
\hline Title & Future learning methods for future jobs \\
\hline $\begin{array}{r}\text { Country } \\
\text { City/Region }\end{array}$ & Austria / Villach \\
\hline Working language & German and English \\
\hline Start/End Date & Date: 03/04/2014; Time: 10:55 - 12:35 \\
\hline Partners Involved & Secondary schools from Villach \\
\hline $\begin{array}{r}\text { Coordinator name } \\
\text { and email }\end{array}$ & $\begin{array}{l}\text { Amir Mujkanovic } \\
\text { A.Mujkanovic@FH-Kaernten.at }\end{array}$ \\
\hline School Profile & $\begin{array}{l}\text { Technical schools with bilingual teaching programs and profiles like } \\
\text { mathematics, physics, chemistry, biology and informatics }\end{array}$ \\
\hline $\begin{array}{r}\text { Number and age } \\
\text { of students }\end{array}$ & 52 students from 4 secondary school, $\approx 14$ years old \\
\hline $\begin{array}{r}\text { Activity } \\
\text { Description }\end{array}$ & $\begin{array}{l}\text { The main goal was to introduce online laboratories embedded into the inquiry } \\
\text { learning cycles. } \\
\text { First they received a brief description of remote labs: what remote labs are, } \\
\text { how you can connect to real hardware over Internet, how you can access } \\
\text { equipment that is geographically detached from the user. This theoretical } \\
\text { demonstration has been underpinned with a live demo of the Radioactivity and } \\
\text { the VISIR labs. } \\
\text { The objective was to gain an impression of students regarding the use of our } \\
\text { labs. Students were asked for their feedback, particularly their preferences on } \\
\text { how the presented ILSs could be improved. }\end{array}$ \\
\hline $\begin{array}{r}\text { Implemented } \\
\text { online labs }\end{array}$ & Radioactivity ILS; VISIR ILS; \\
\hline $\begin{array}{r}\text { Learning } \\
\text { outcomes }\end{array}$ & $\begin{array}{l}\text { Students are interested in working with Online Labs or other learning tools that } \\
\text { involve ICT. Some of them were interested in technical details. One student for } \\
\text { example was interested in software programming that is related to providing } \\
\text { lab equipment online. Most other students would like to use this kind of } \\
\text { learning as an opportunity to research more and to use online laboratories as } \\
\text { an additional tool. } \\
\text { The overall impression was very positive. Students were engaged in the } \\
\text { activities and enjoyed the learning experience with the labs. Most students } \\
\text { suggested that these labs should be embedded in the classroom as additional } \\
\text { activities. Some students however were not fully engaged in these activities but } \\
\text { they would accept the usage of labs as an optional activity. } \\
\text { Another observation was that students would prefer to have an introduction } \\
\text { and guidance by their teachers when they use online labs for the first time. }\end{array}$ \\
\hline
\end{tabular}




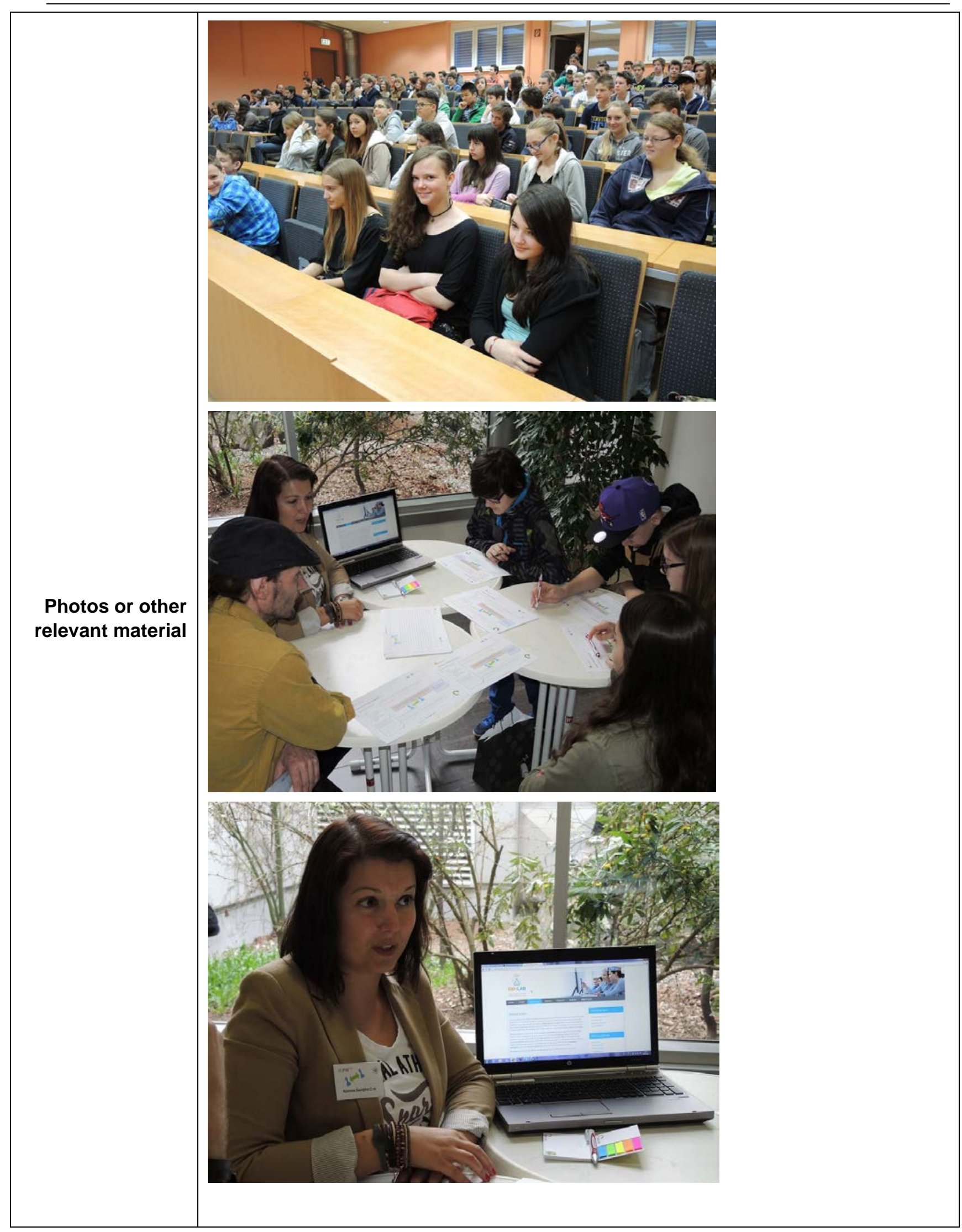




\begin{tabular}{|c|c|}
\hline $\begin{array}{r}\text { G O - L A B } \\
\text { Report Code }\end{array}$ & AT13-070714 \\
\hline Title & Implementation Activity \\
\hline $\begin{array}{r}\text { Country } \\
\text { City/Region }\end{array}$ & Austria / Villach \\
\hline Working language & German \\
\hline Start/End Date & Date: 07/07/2014; Time: 10:00 - 11:00 \\
\hline Partners Involved & CUAS \\
\hline $\begin{array}{r}\text { Coordinator name } \\
\text { and email }\end{array}$ & $\begin{array}{l}\text { Amir Mujkanovic } \\
\text { A.Mujkanovic@FH-Kaernten.at }\end{array}$ \\
\hline School Profile & Various teachers from 6 different schools \\
\hline $\begin{array}{r}\text { Number and age } \\
\text { of students }\end{array}$ & 6 teachers \\
\hline $\begin{array}{r}\text { Activity } \\
\text { Description }\end{array}$ & $\begin{array}{l}\text { The main goal was to introduce online laboratories embedded into the inquiry } \\
\text { learning cycles. } \\
\text { First they received a brief description of remote labs: what remote labs are, how } \\
\text { you can connect to real hardware over Internet, how you can access equipment } \\
\text { that is geographically detached from the user. This theoretical demonstration has } \\
\text { been underpinned with a live demo of the Radioactivity labs. } \\
\text { The objective was to gain an impression of teachers regarding the use of our } \\
\text { labs. Teachers were asked for their feedback, particularly their preferences on } \\
\text { how the presented ILSs could be improved. }\end{array}$ \\
\hline $\begin{array}{r}\text { Implemented } \\
\text { online labs }\end{array}$ & Radioactivity ILS \\
\hline $\begin{array}{l}\text { Learning } \\
\text { outcomes }\end{array}$ & $\begin{array}{l}\text { Participants of this online workshop were interested in working with Online } \\
\text { Labs and the Go-Lab infrastructure. Some of the participants promised to } \\
\text { inform CUAS about upcoming conferences related to eLearning. These } \\
\text { conferences might provide important opportunities for additional steps in the } \\
\text { community building. } \\
\text { Teaches used the Radioactivity ILS during the workshop. Some of them had } \\
\text { technical difficulties accessing the lab that is embedded in the investigation } \\
\text { phase. However, most of them could access the lab and perform the } \\
\text { experiment. } \\
\text { The facilitators' overall impression was very positive. Teachers were engaged } \\
\text { in the activities and enjoyed the experience with the ILS. }\end{array}$ \\
\hline
\end{tabular}




\subsection{Belgium}

EUN conducted and coordinated the implementation activities in Belgium, and also in France and Spain, listed in the table below. As already mentioned in other sections of the document, EUN has a European status rather than a national one and so its target audience, in terms of teachers and pilot schools, are coming from European countries in general and not only from the partner's host country. In this context three training activities for science teachers were organized, the two of which were combined visionary workshops with short hands-on sessions before the official Phase-A period, with 73 participants, where a variety of labs were introduced and practiced. The subject domains of these activities and labs were focused mainly on physics and astronomy.

\begin{tabular}{|l|l|l|l|l|}
\hline Date(s) & Type & $\begin{array}{l}\text { Participants } \\
\text { (Schools) }\end{array}$ & Labs & Subject(s) \\
\hline $15 / 02 / 2014$ & $\begin{array}{l}\text { Training of } \\
\text { teachers }\end{array}$ & $15(15)$ & Hypatia, Galaxy-crash & $\begin{array}{l}\text { Physics, } \\
\text { Astronomy }\end{array}$ \\
\hline $02 / 03 / 2013$ & $\begin{array}{l}\text { Training of } \\
\text { teachers }\end{array}$ & $28(20)$ & $\begin{array}{l}\text { Faulkes-Telescope, Aquarium, } \\
\text { Hypatia, Sun4all, Cernland }\end{array}$ & $\begin{array}{l}\text { Physics, } \\
\text { Astronomy }\end{array}$ \\
\hline $10 / 03 / 2013$ & $\begin{array}{l}\text { Training of } \\
\text { teachers }\end{array}$ & $30(22)$ & $\begin{array}{l}\text { Faulkes-Telescope, Aquarium, } \\
\text { Hypatia, Sun4all, Cernland }\end{array}$ & $\begin{array}{l}\text { Physics, } \\
\text { Astronomy }\end{array}$ \\
\hline
\end{tabular}

In the following the detailed reports from the activities are shown. 


\begin{tabular}{|c|c|}
\hline $\begin{array}{l}\text { G O - L A B } \\
\text { Event Code }\end{array}$ & [BEEUN-150214] \\
\hline Title & Go-Lab Inquiry Learning at Schools \\
\hline $\begin{array}{r}\text { Country } \\
\text { City/Region }\end{array}$ & $\begin{array}{l}\text { Belgium } \\
\text { Brussels }\end{array}$ \\
\hline Working language & English \\
\hline Start/End Date & $15 / 02 / 2014$ \\
\hline $\begin{array}{r}\text { Organizing } \\
\text { Institute }\end{array}$ & European Schoolnet \\
\hline $\begin{array}{r}\text { Coordinator name } \\
\text { and email }\end{array}$ & $\begin{array}{l}\text { Evita Tasiopoulou } \\
\text { Evita.tasiopoulou@eun.org }\end{array}$ \\
\hline Activity Form & Workshop \\
\hline Activity Type & International workshop with teachers from a variety of EU countries \\
\hline $\begin{array}{l}\text { Total number of } \\
\text { teachers/schools }\end{array}$ & 15 \\
\hline $\begin{array}{r}\text { Implemented } \\
\text { online labs }\end{array}$ & Hypatia, Galaxy crash \\
\hline Brief description & $\begin{array}{l}\text { The aim of the workshop was to introduce teachers to Go-Lab and get them } \\
\text { excited about the possibilities that the project has to offer to their teaching. } \\
\text { The session started with an introduction to the project, its aims and main } \\
\text { outcomes. A demonstration of two laboratories (Hypatia \& Galaxy crash) } \\
\text { followed. A quick introduction to the Go-Lab inquiry learning cycle and } \\
\text { teachers' experience with inquiry learning has also taken place. } \\
\text { The second part of the training focused on a hand on activity combined with } \\
\text { the running Go-Lab competition. Teachers had the opportunity to go through } \\
\text { the available laboratories and start working on a lesson plan/contribution to the } \\
\text { competition. }\end{array}$ \\
\hline $\begin{array}{l}\text { Learning } \\
\text { outcomes }\end{array}$ & $\begin{array}{l}\text { After following this workshop, teachers have learnt the following: } \\
\text { - } \quad \text { Aims and future outcomes of the project } \\
\text { - Inquiry learning based cycle } \\
\text { - } \quad \text { Use of online laboratories \& a few inspiring examples } \\
\text { - } \quad \text { How they can get involved and participate further to the project } \\
\text { - } \quad \text { Go-Lab competition }\end{array}$ \\
\hline
\end{tabular}




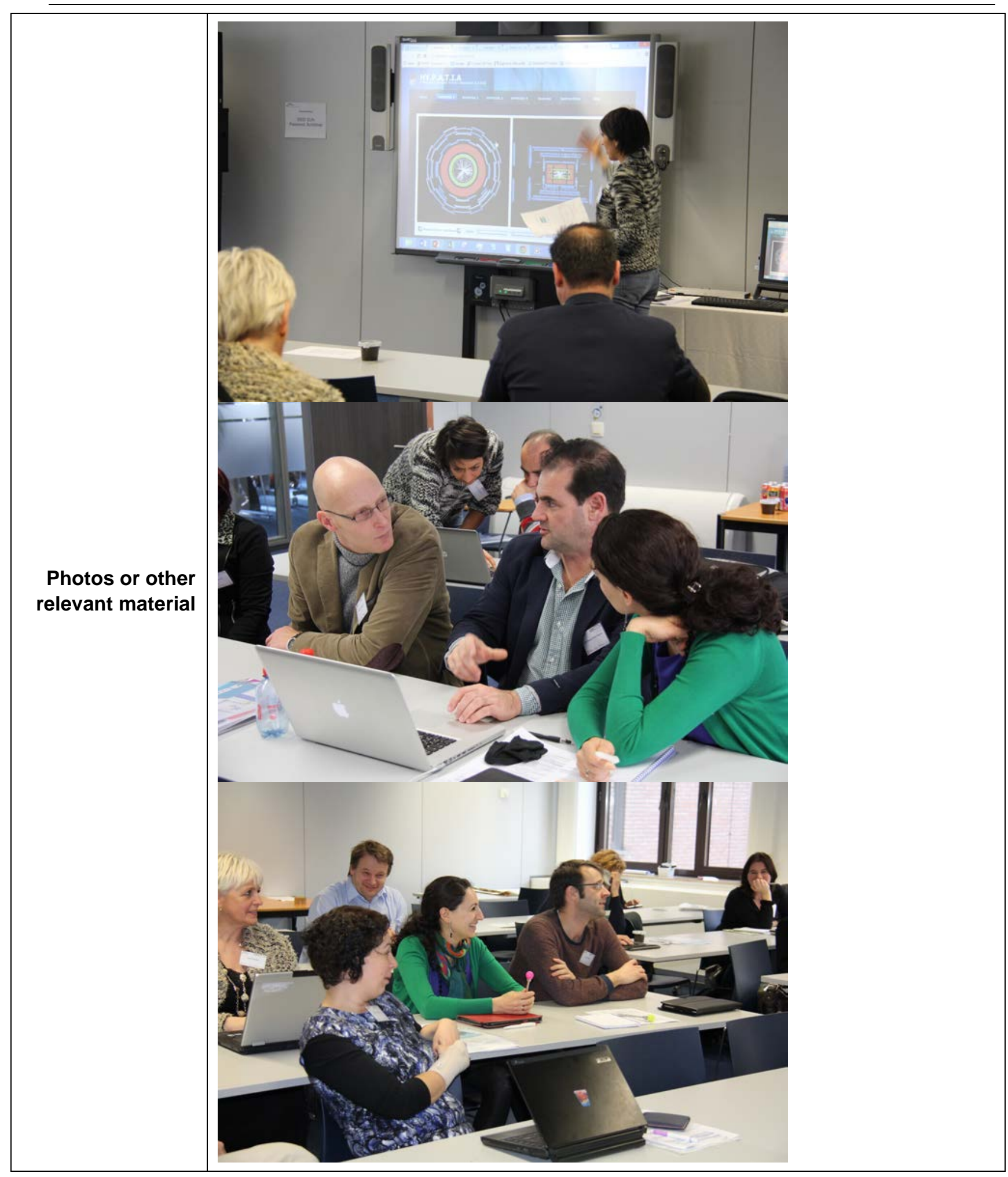




\begin{tabular}{|c|c|}
\hline $\begin{array}{l}\text { G O - L A B } \\
\text { Event Code }\end{array}$ & FREUN-020313 \\
\hline Title & Go-Lab Training and Visionary workshop \\
\hline $\begin{array}{r}\text { Country } \\
\text { City/Region }\end{array}$ & $\begin{array}{l}\text { France } \\
\text { Tours }\end{array}$ \\
\hline Working language & English \\
\hline Start/End Date & $02 / 03 / 2013$ \\
\hline $\begin{array}{r}\text { Organizing } \\
\text { Institute }\end{array}$ & European Schoolnet \\
\hline $\begin{array}{r}\text { Coordinator name } \\
\text { and email }\end{array}$ & $\begin{array}{l}\text { Evita Tasiopoulou } \\
\text { Evita.tasiopoulou@eun.org }\end{array}$ \\
\hline Activity Form & Visionary workshop and Hands-on Training \\
\hline Activity Type & $\begin{array}{l}\text { International } \\
\text { Workshop for teachers }\end{array}$ \\
\hline $\begin{array}{l}\text { Total number of } \\
\text { teachers/schools }\end{array}$ & 28 teachers from 20 schools \\
\hline $\begin{array}{r}\text { Implemented } \\
\text { online labs }\end{array}$ & Faulkes Telescopes, Aquarium Web Lab, HYPATIA, Sun4all, CERNland \\
\hline Brief description & $\begin{array}{l}\text { The Go-Lab Visionary workshop purpose was to show teachers the use of the } \\
\text { remote lab and how it can be combined with the theoretical background and } \\
\text { educational resources. The workshop was divided into two sections. The first } \\
\text { part was devoted in the presentation of Go-Lab project, its aims and main } \\
\text { benefits for teachers, students and laboratory owners. } \\
\text { The second part was focused on hands on activities. Using the Day on Jupiter } \\
\text { example, we guided teachers through a possible activity and reviewed the use } \\
\text { of the inquiry based model. Then five online laboratories that will be included in } \\
\text { Go-Lab were presented and teachers, split in small teams, had to spend a } \\
\text { certain time working on a lesson plan based on one of the suggested } \\
\text { laboratories (using IBSE). } \\
\text { At the end, teachers presented their work to their colleagues and had the } \\
\text { opportunity to talk about the challenges they face and the possibilities they see } \\
\text { in the use of the Go-Lab portal. } \\
\text { Finally participants have been asked to fill in an on-line survey in order to } \\
\text { collect the main ideas of the groups and their overall feedback. }\end{array}$ \\
\hline $\begin{array}{l}\text { Learning } \\
\text { outcomes }\end{array}$ & $\begin{array}{l}\text { Participants were expected to have an overall idea on the added value of on- } \\
\text { line labs, the need for organizing them into a federation and how could Go-Lab } \\
\text { assist them in their teaching by providing, a federation of labs, relative } \\
\text { educational activities and supporting tools for their implementation. }\end{array}$ \\
\hline
\end{tabular}




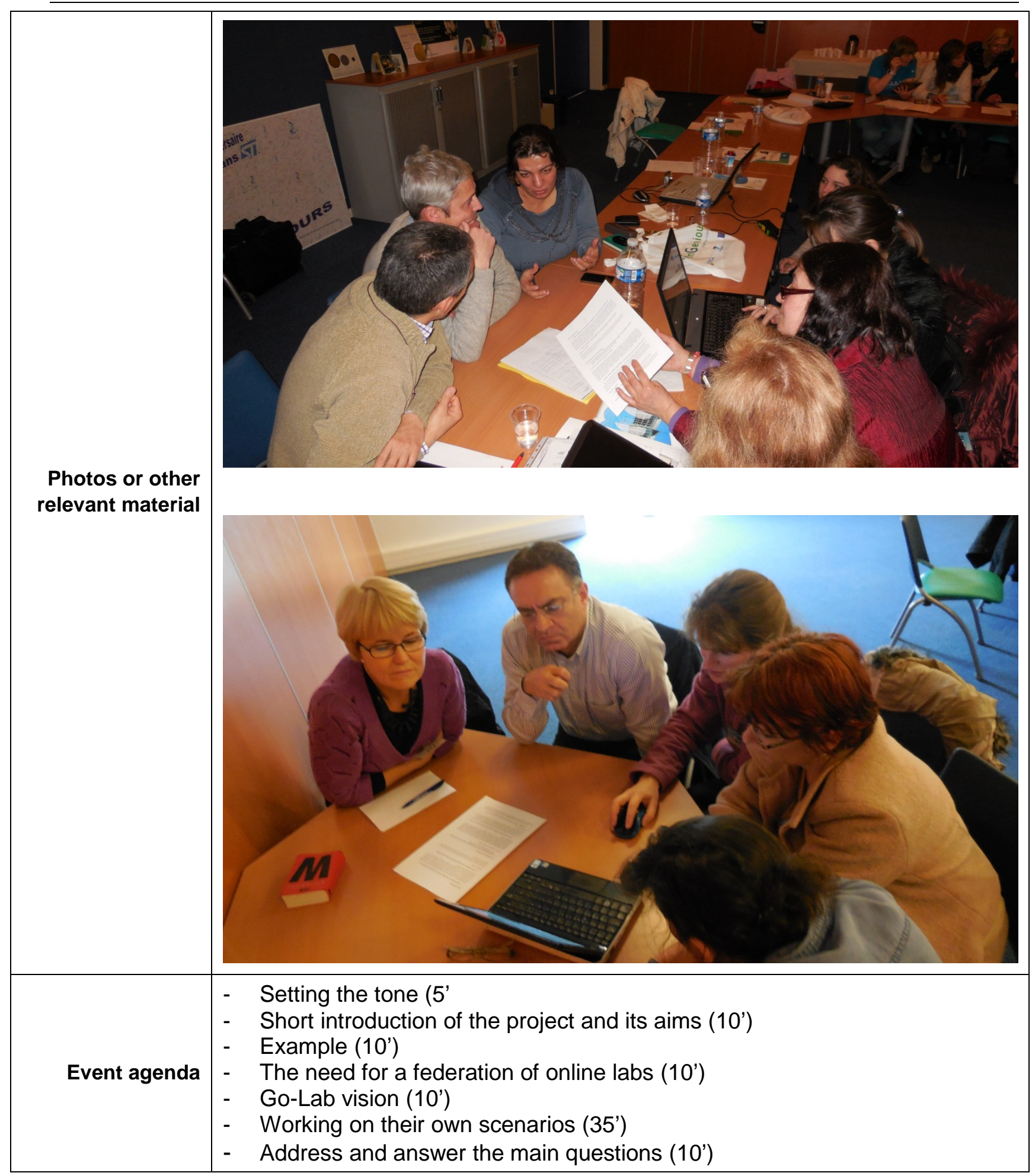




\begin{tabular}{|c|c|}
\hline $\begin{array}{l}\text { G O - L A B } \\
\text { Event Code }\end{array}$ & ESEUN-100313 \\
\hline Title & Go-Lab Training and Visionary workshop \\
\hline $\begin{array}{r}\text { Country } \\
\text { City/Region }\end{array}$ & $\begin{array}{l}\text { Spain } \\
\text { Madrid }\end{array}$ \\
\hline Working language & English \\
\hline Start/End Date & $10 / 03 / 2013$ \\
\hline $\begin{array}{r}\text { Organizing } \\
\text { Institute }\end{array}$ & European Schoolnet \\
\hline $\begin{array}{r}\text { Coordinator name } \\
\text { and email }\end{array}$ & $\begin{array}{l}\text { Gina Mihai } \\
\text { Gina.mihai@eun.org }\end{array}$ \\
\hline Activity Form & Visionary workshop and Hands-on Training \\
\hline Activity Type & $\begin{array}{l}\text { International } \\
\text { Workshop for teachers }\end{array}$ \\
\hline $\begin{array}{l}\text { Total number of } \\
\text { teachers/schools }\end{array}$ & 30 teachers from 22 schools \\
\hline $\begin{array}{r}\text { Implemented } \\
\text { online labs }\end{array}$ & Faulkes Telescopes, Aquarium WebLab, HYPATIA, Sun4all, CERNland \\
\hline Brief description & $\begin{array}{l}\text { The Go-Lab Visionary workshop purpose was to show teachers the use of the } \\
\text { remote lab and how it can be combined with the theoretical background and } \\
\text { educational resources. The workshop was divided into two sections. The first } \\
\text { part was devoted in the presentation of Go-Lab project, its aims and main } \\
\text { benefits for teachers, students and laboratory owners. } \\
\text { The second part was focused on hands on activities. Using the Day on Jupiter } \\
\text { example, we guided teachers through a possible activity and reviewed the use } \\
\text { of the inquiry based model. Then five online laboratories that will be included in } \\
\text { Go-Lab were presented and teachers, split in small teams, had to spend a } \\
\text { certain time working on a lesson plan based on one of the suggested } \\
\text { laboratories (using IBSE). } \\
\text { At the end, teachers presented their work to their colleagues and had the } \\
\text { opportunity to talk about the challenges they face and the possibilities they see } \\
\text { in the use of the Go-Lab portal. } \\
\text { Finally participants have been asked to fill in an on-line survey in order to } \\
\text { collect the main ideas of the groups and their overall feedback. }\end{array}$ \\
\hline $\begin{array}{l}\text { Learning } \\
\text { outcomes }\end{array}$ & $\begin{array}{l}\text { Participants were expected to have an overall idea on the added value of on- } \\
\text { line labs, the need for organizing them into a federation and how could Go-Lab } \\
\text { assist them in their teaching by providing, a federation of labs, relative } \\
\text { educational activities and supporting tools for their implementation. }\end{array}$ \\
\hline
\end{tabular}




\begin{tabular}{|c|c|}
\hline Website & $\mathrm{n} / \mathrm{a}$ \\
\hline Event agenda & $\begin{array}{l}\text { - Setting the tone (5' } \\
-\quad \text { Short introduction of the project and its aims (10') } \\
-\quad \text { Example (10') } \\
-\quad \text { The need for a federation of online labs (10') } \\
-\quad \text { Go-Lab vision (10') } \\
-\quad \text { Working on their own scenarios (35') } \\
-\quad \text { Address and answer the main questions (10') }\end{array}$ \\
\hline
\end{tabular}




\subsection{Cyprus}

UCY is the national coordinator of implementation in Cyprus. During Phase-A there were no activities to be reported since the schools and teachers contacted finally opted out to wait for implementation of the newer release of the GoLab platform (i.e. the repository of labs and ILSs and the authoring tool, graasp). In the period covered by this document UCY collaborated closely with two science teachers from local high-schools working on the design and development of lesson plans and ILS with the Electricity lab. The developed ILSs and support materials are planned to be utilized by pilot schools in Phase-B.

\subsection{Estonia}

UTE is the national coordinator of implementation in Estonia. The case is similar as above. In the Phase-A period UTE collaborated closely with four science teachers, in particular teachers of biology and chemistry, and worked on the design and development of lesson plans and ILSs with a set of proposed biology labs that were not on the repository at that time. The labs they proposed were officially reported to WP2 and are now included in the repository. The developed ILSs are planned to be utilized by pilot schools in Phase-B.

\subsection{Germany}

UDE is the national coordinator of implementation in Germany. During Phase-A there were no activities to be reported since the majority of schools and teachers contacted finally opted out to wait for implementation of the newer release of the GoLab platform (i.e. the repository of labs and ILSs and the authoring tool, graasp) with enriched content in terms of labs and subject domains. In the period covered by this document UDE collaborated closely with two science teachers from local high-schools working on the design and development of lesson plans and an ILS focusing on curriculum subjects of chemistry, environmental science and ecology. The developed ILS and proposed lab, Osmotic power, are planned to be utilized by pilot schools in Phase-B. 


\subsection{Greece}

EA is the national coordinator of implementation in Greece. It organized a variety of training and educational activities for science teachers and students around the country. A lot of activities were also held in collaboration with IASA, the lab provider of HYPATIA. In total, in Phase-A there were 2 teacher training events, with 46 participants, and 9 activities with students, with 278 participants, on a variety of subjects and labs, covering physics, astronomy, maths and technology (see table below). In total 68 secondary schools were involved in these activities. Phase-A concluded with the Go-Lab Summer School, organized by EA in Marathon on 13-18 Jul 2014, in collaboration with partners of the consortium. The summer school was a week-long intensive course on the use of online labs is science education. 39 teachers from countries around Europe participated and developed 39 ILSs on various curriculum topics using in full the Go-Lab repository and authoring tool (details about the summer school and teachers contest are given in D6.4 [5]).

\begin{tabular}{|c|c|c|c|c|c|}
\hline Partner(s) & Date(s) & Type & $\begin{array}{l}\text { Participants } \\
\text { (Schools) }\end{array}$ & Labs & Subject(s) \\
\hline EA & $\begin{array}{l}01 / 02 / 2014- \\
31 / 03 / 2014\end{array}$ & $\begin{array}{l}\text { Activity with } \\
\text { students }\end{array}$ & $10(1)$ & Splash, PhET & Physics \\
\hline $\mathrm{EA}$ & $10 / 02 / 2014$ & $\begin{array}{l}\text { Activity with } \\
\text { students }\end{array}$ & $20(1)$ & $\begin{array}{l}\text { ESA-SOHO dataset, } \\
\text { SalsaJ, Geogebra }\end{array}$ & $\begin{array}{l}\text { Maths, } \\
\text { Physics, } \\
\text { Astronomy }\end{array}$ \\
\hline $\mathrm{EA}$ & $11 / 03 / 2014$ & $\begin{array}{l}\text { Activity with } \\
\text { students }\end{array}$ & $28(1)$ & iSpyCMS & $\begin{array}{l}\text { Physics, } \\
\text { Technology }\end{array}$ \\
\hline EA & $\begin{array}{l}01 / 04 / 2014- \\
07 / 05 / 2014\end{array}$ & $\begin{array}{l}\text { Activity with } \\
\text { students }\end{array}$ & $35(7)$ & Splash, PhET & Physics \\
\hline EA, IASA & $29 / 04 / 2014$ & $\begin{array}{l}\text { Training of } \\
\text { teachers }\end{array}$ & $22(19)$ & Hypatia & Physics \\
\hline EA, IASA & $20 / 05 / 2014$ & $\begin{array}{l}\text { Training of } \\
\text { teachers }\end{array}$ & $24(20)$ & Hypatia & Physics \\
\hline EA & 09/05/2014 & $\begin{array}{l}\text { Activity with } \\
\text { students }\end{array}$ & $42(1)$ & iSpyCMS & $\begin{array}{l}\text { Physics, } \\
\text { Technology }\end{array}$ \\
\hline IASA & $24 / 01 / 2014$ & $\begin{array}{l}\text { Activity with } \\
\text { students }\end{array}$ & $28(4)$ & Hypatia & Physics \\
\hline IASA & $19 / 02 / 2014$ & $\begin{array}{l}\text { Activity with } \\
\text { students }\end{array}$ & $25(4)$ & Hypatia & Physics \\
\hline IASA & $04 / 02 / 2014$ & $\begin{array}{l}\text { Activity with } \\
\text { students }\end{array}$ & $45(5)$ & Hypatia & Physics \\
\hline IASA & $10 / 03 / 2014$ & $\begin{array}{l}\text { Activity with } \\
\text { students }\end{array}$ & $45(5)$ & Hypatia & Physics \\
\hline $\begin{array}{l}\text { EA (organizer) } \\
\text { and EPFL, } \\
\text { UOG, } \\
\text { NUCLIO, UTE, } \\
\text { ULEIC }\end{array}$ & $\begin{array}{l}13 / 07 / 2014- \\
18 / 07 / 2014\end{array}$ & $\begin{array}{l}\text { Training of } \\
\text { teachers }\end{array}$ & $39(38)$ & $\begin{array}{l}\text { Faulkes Telescopes, } \\
\text { Crashing Galaxies, } \\
\text { SalsaJ, Craters, } \\
\text { Electricity lab, Splash, } \\
\text { HYPATIA }\end{array}$ & $\begin{array}{l}\text { Physics, } \\
\text { Technology, } \\
\text { Biology, } \\
\text { Ecology, } \\
\text { Astronomy }\end{array}$ \\
\hline
\end{tabular}

In the following the detailed reports from the activities in Greece are shown. 


\begin{tabular}{|c|c|}
\hline $\begin{array}{r}\text { G O - L A B } \\
\text { Report Code }\end{array}$ & GR02-01022014 \\
\hline Title & "Ship design" or "Little crafts and great challenges" \\
\hline $\begin{array}{r}\text { Country } \\
\text { City/Region }\end{array}$ & Greece, Pallini Athens \\
\hline Working language & Greek and English \\
\hline Start/End Date & 01/02/2014 - 31/03/2014 \\
\hline Partners Involved & EA \\
\hline $\begin{array}{r}\text { Coordinator name } \\
\text { and email }\end{array}$ & G.Mavromanolakis gmavroma@ea.gr \\
\hline School Profile & $\begin{array}{l}\text { Junior high-school (Gymnasium) of Ellinogermaniki Agogi. The school and staff } \\
\text { has proven track record on using innovative teaching methods and extra- } \\
\text { curricular interdisciplinary educational activities }\end{array}$ \\
\hline $\begin{array}{r}\text { Number and age } \\
\text { of students }\end{array}$ & 10 junior high school students, age $13-15$ years old \\
\hline $\begin{array}{r}\text { Activity } \\
\text { Description }\end{array}$ & $\begin{array}{l}\text { The educational activity consists of a series of inquiry-learning sessions, each } \\
\text { about two hours long. It is conducted on a weekly basis as extra-curricular } \\
\text { project assignment for students with interests in STEM. It covers and } \\
\text { complements the teaching of the following curriculum subjects: physics, maths, } \\
\text { technology and engineering. In this activity students split into groups and use a } \\
\text { professional tool to design a ship to carry a payload. They build a model with } \\
\text { simple materials and test it in a physical lab. They elaborate their knowledge } \\
\text { with virtual or remote labs and simulations. In the final stage of the activity the } \\
\text { teams of students may compete with their models in a swimming pool. } \\
\text { In brief the activity develops as the following: students start by experimenting } \\
\text { with the use of a virtual lab or simulation to learn and elaborate on subjects like } \\
\text { forces, buoyancy, weight, mass, density (all these have direct connection to } \\
\text { science curriculum of middle or high school level). They then split into teams } \\
\text { and are assigned/challenged to build a water-tight, strong, stable, streamlined } \\
\text { vessel to carry a payload using only certain every-day life low-cost materials } \\
\text { (e.g. skewers, aluminum foil and baking paper). They study, test and improve } \\
\text { their design and construction in a physical lab (with water tank and } \\
\text { dynamometers). They have also to document (written report) and communicate } \\
\text { (presentation/poster) the various steps of their project. At the end the teams } \\
\text { compete with their models in a swimming pool using simple pulling } \\
\text { mechanisms (fishing reels). } \\
\text { One of the main advantages of this activity is that it consists of several sub- } \\
\text { activities each of which gives the flexibility to the teacher to introduce inquiry- } \\
\text { based approach of various subjects of the science curriculum such as forces, } \\
\text { motion, Newton's laws, equilibrium, buoyancy, mass, density etc. and let the } \\
\text { students to acquire, develop and explore the relevant knowledge. Also a key }\end{array}$ \\
\hline
\end{tabular}




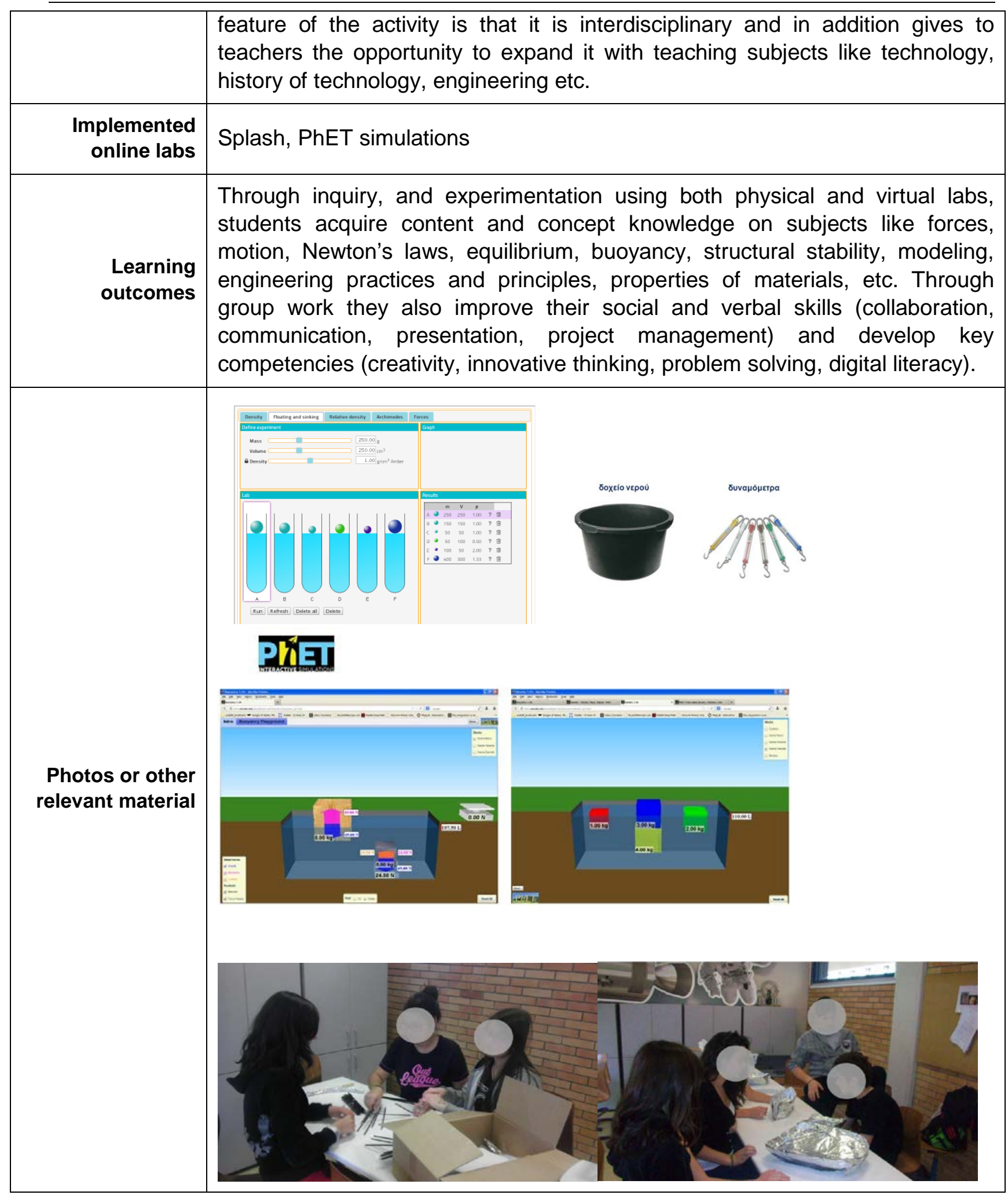




\begin{tabular}{|c|c|}
\hline $\begin{array}{r}\text { G O - L A B } \\
\text { Report Code }\end{array}$ & GR02-10022014 \\
\hline Title & High school students measure the self-rotation period of the Sun \\
\hline $\begin{array}{r}\text { Country } \\
\text { City/Region }\end{array}$ & Greece, Pallini Athens \\
\hline Working language & Greek and English \\
\hline Start/End Date & $10 / 02 / 2014$ \\
\hline Partners Involved & EA \\
\hline $\begin{array}{r}\text { Coordinator name } \\
\text { and email }\end{array}$ & G.Mavromanolakis gmavroma@ea.gr \\
\hline School Profile & $\begin{array}{l}\text { High-school (Lyceum) of Ellinogermaniki Agogi. The school and staff has } \\
\text { proven track record on using innovative teaching methods and extra-curricular } \\
\text { interdisciplinary educational activities }\end{array}$ \\
\hline $\begin{array}{r}\text { Number and age } \\
\text { of students }\end{array}$ & 20 high school students, age $16-17$ years old \\
\hline $\begin{array}{r}\text { Activity } \\
\text { Description }\end{array}$ & $\begin{array}{l}\text { The teaching activity was developed in collaboration with maths and physics } \\
\text { teachers and is directly linked to the maths/geometry and physics curriculum } \\
\text { (specific topics: trigonometry functions, circular motion). In this activity students } \\
\text { measure the Sun's self-rotation period by using real data from the spacecraft } \\
\text { SOHO and applying a simple mathematical formula which they have derived. } \\
\text { By investigating an engaging question like "Does the Sun rotate?" or "Is the } \\
\text { Sun a solid object?" they get a better understanding of the relation between } \\
\text { maths, science and technology. } \\
\text { Usually students complain that they find no interest in maths and relevant } \\
\text { subjects like geometry, algebra and trigonometry because they are too abstract } \\
\text { or have no relation to their everyday life. This activity is designed to } \\
\text { demonstrate to students the relation of mathematics to science and } \\
\text { technology. Students are first asked to solve a simple problem of geometry and } \\
\text { derive a formula which is then applied to answer an engaging question like } \\
\text { "Does the Sun rotate?" or "Is the Sun a solid object?" They then use images of } \\
\text { sunspots taken from the spacecraft SOHO (solar heliospheric observatory) and } \\
\text { with the help of simple image processing software and the application of the } \\
\text { derived formula can actually measure the Sun's period of self-rotation or the } \\
\text { differential rotation across latitude. Before they are guided to do so they can } \\
\text { make various hypotheses on how or what is the correct answer. At the end of } \\
\text { the activity they can compare their results and also discuss how a simple } \\
\text { abstract formula can be applied in answering a scientific question. }\end{array}$ \\
\hline $\begin{array}{l}\text { Implemented } \\
\text { online labs }\end{array}$ & ESA-SOHO dataset, SalsaJ, Geogebra \\
\hline
\end{tabular}




\begin{tabular}{|c|c|}
\hline $\begin{array}{r}\text { Learning } \\
\text { outcomes }\end{array}$ & $\begin{array}{l}\text { Students get a better understanding of the relation between maths, science and } \\
\text { technology. They use real scientific data to answer a scientific question. They } \\
\text { develop and practice their digital skills by using online resources and tools. }\end{array}$ \\
\hline $\begin{array}{l}\text { Photos or other } \\
\text { relevant material }\end{array}$ & 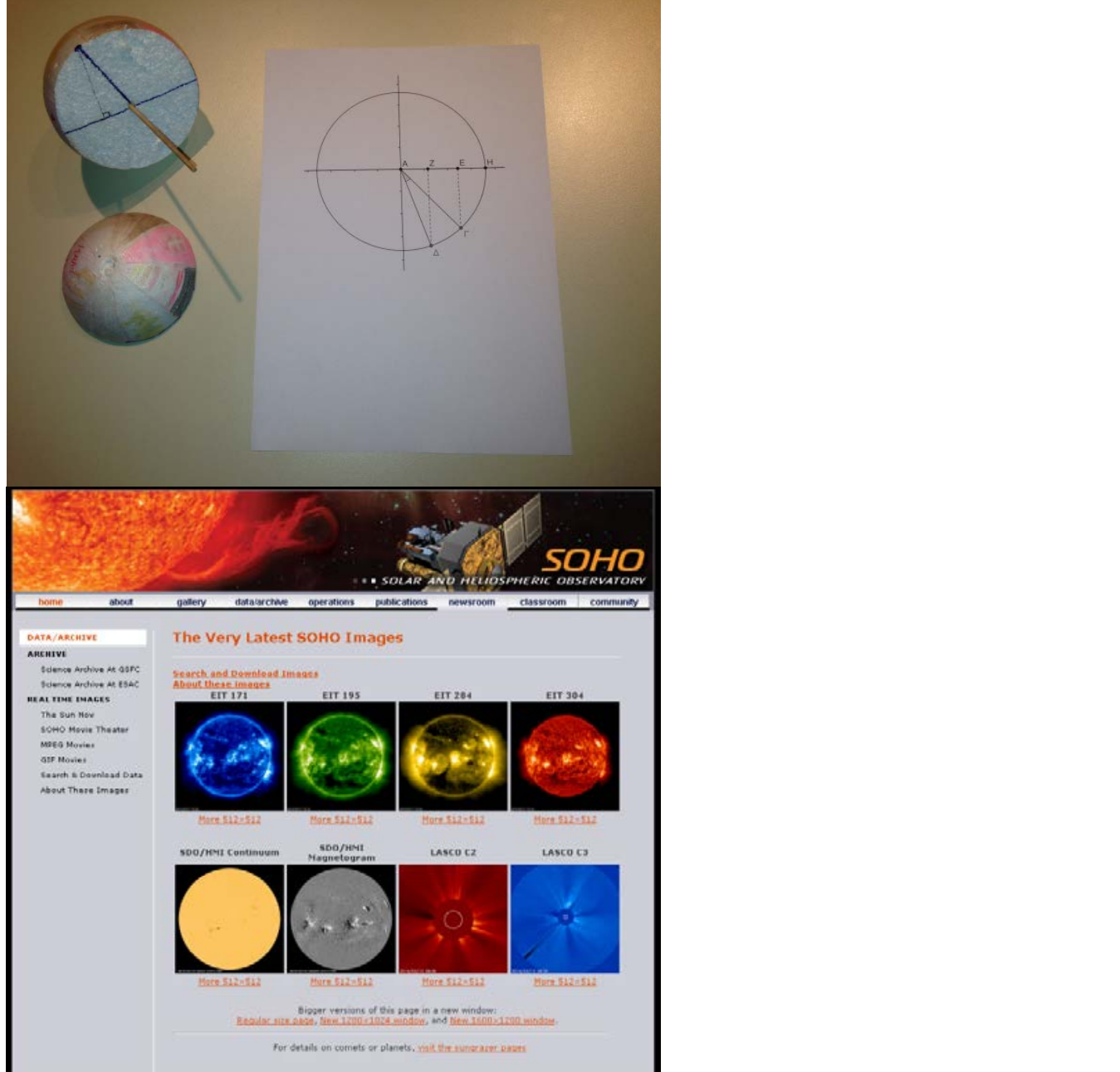 \\
\hline & 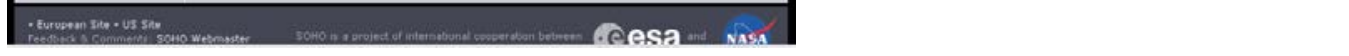 \\
\hline
\end{tabular}




\begin{tabular}{|c|c|}
\hline $\begin{array}{r}\text { G O - L A B } \\
\text { Report Code }\end{array}$ & GR02-11032014 \\
\hline Title & High school students analyze data from particle physics experiment at CERN \\
\hline $\begin{array}{r}\text { Country } \\
\text { City/Region }\end{array}$ & Greece, Athens \\
\hline Working language & Greek and English \\
\hline Start/End Date & $11 / 03 / 2014$ \\
\hline Partners Involved & EA \\
\hline $\begin{array}{r}\text { Coordinator name } \\
\text { and email }\end{array}$ & G.Mavromanolakis gmavroma@ea.gr \\
\hline School Profile & $\begin{array}{l}\text { High-school "Platon" (Lyceum). The school has long tradition of participation in } \\
\text { EU educational projects and on implementing innovative teaching methods and } \\
\text { technologies }\end{array}$ \\
\hline $\begin{array}{r}\text { Number and age } \\
\text { of students }\end{array}$ & 28 ( 2 classes) of high school students, age $16-17$ years old \\
\hline $\begin{array}{r}\text { Activity } \\
\text { Description }\end{array}$ & $\begin{array}{l}\text { The educational activity consists of two parts, each about two hours long, } \\
\text { implemented on } 11 / 03 / 2014 \text { and on } 10 / 04 / 2014 \text { respectively. In the former part } \\
\text { students attend a lecture by G. Mavromanolakis (former researcher at CERN) } \\
\text { on particle physics research, science and technology. This is followed by a } \\
\text { virtual visit to CERN in live connection with other schools around the country } \\
\text { (see photo below). In the second part of the activity students analyze data from } \\
\text { the CMS particle physics experiment at the Large Hadron Collider of CERN } \\
\text { using the iSpyCMS online lab (dataset and event display/analysis tool). }\end{array}$ \\
\hline $\begin{array}{r}\text { Implemented } \\
\text { online labs }\end{array}$ & iSpyCMS (dataset and event display/analysis) \\
\hline $\begin{array}{l}\text { Learning } \\
\text { outcomes }\end{array}$ & $\begin{array}{l}\text { Students get a better understanding how frontier scientific research is } \\
\text { conducted, how cutting edge technologies are developed, what is the everyday } \\
\text { job of researchers, scientists and engineers is in a large international research } \\
\text { center etc. They use real scientific data to investigate and answer a scientific } \\
\text { question. They develop and practice their digital skills by using online } \\
\text { resources and tools. They understand how abstract concepts from their } \\
\text { physics curriculum like the principles of "conservation of energy and } \\
\text { momentum" and "conservation of charge" are applied and manifested in the } \\
\text { microcosmos. }\end{array}$ \\
\hline
\end{tabular}




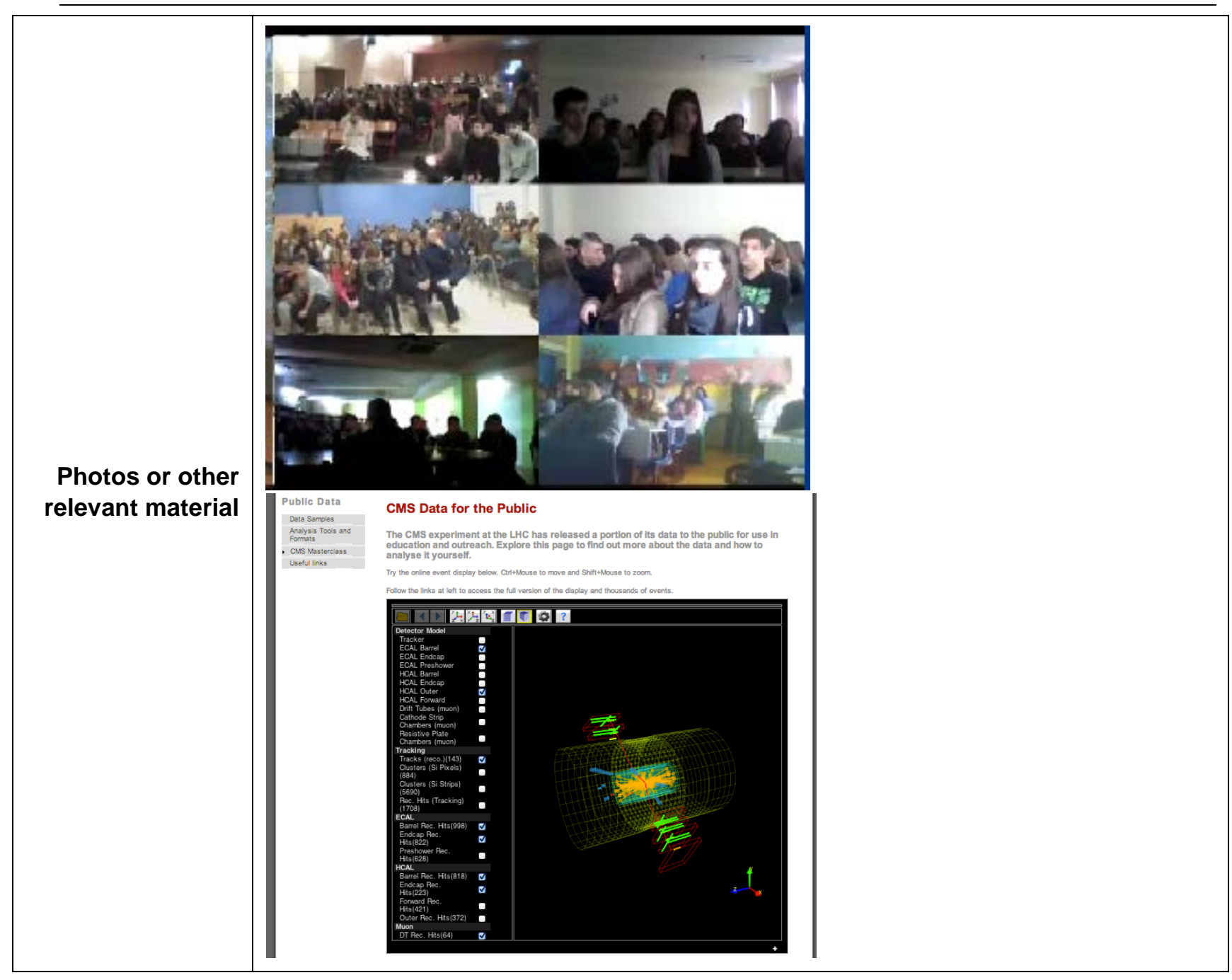




\begin{tabular}{|c|c|}
\hline $\begin{array}{r}\text { G O - L A B } \\
\text { Report Code }\end{array}$ & GR02-01042014 \\
\hline Title & $\begin{array}{l}\text { "Little crafts and great challenges" educational contest for junior high school } \\
\text { students }\end{array}$ \\
\hline $\begin{array}{r}\text { Country } \\
\text { City/Region }\end{array}$ & Greece, Kerkyra \\
\hline Working language & Greek \\
\hline Start/End Date & 01/04/2014-07/05/2014 \\
\hline Partners Involved & EA \\
\hline $\begin{array}{r}\text { Coordinator name } \\
\text { and email }\end{array}$ & 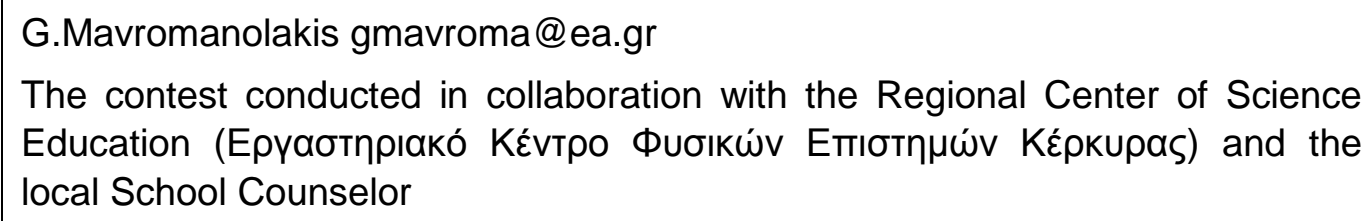 \\
\hline School Profile & $\begin{array}{l}13 \text { student teams from } 7 \text { rural and urban junior high-schools (Gymnasia) of } \\
\text { Kerkyra island. The local community of teachers, principal and counselor of } \\
\text { science education, have proven track record on innovative teaching and } \\
\text { organization of extra-curricular interdisciplinary educational activities and contests }\end{array}$ \\
\hline $\begin{array}{r}\text { Number and age } \\
\text { of students }\end{array}$ & 35 (20 male, 15 female) junior high school students, age 13-15 years old \\
\hline $\begin{array}{r}\text { Activity } \\
\text { Description }\end{array}$ & $\begin{array}{l}\text { The activity "Little crafts and great challenges" was formed as a science and } \\
\text { technology contest for schools (pictures shown below is from the relevant } \\
\text { webpage with description/registration for the contest). It involves a collection of } \\
\text { inquiry activities related to several science subjects including physics, maths, } \\
\text { technology and engineering. In these series of activities students form teams } \\
\text { and are challenged to design, study and build a ship with certain only materials } \\
\text { to carry a payload. They build a model with simple materials and test it in a } \\
\text { physical lab. They elaborate their knowledge with virtual labs (ie Splash) and } \\
\text { simulations (PhET applets). At the end they have to make a presentation about } \\
\text { their project. In the final stage of the activity the teams of students compete } \\
\text { with their models in a water pool. The final part of the contest was kindly } \\
\text { hosted by the local sailing club (see photos below). }\end{array}$ \\
\hline $\begin{array}{r}\text { Implemented } \\
\text { online labs }\end{array}$ & Splash, PhET simulations \\
\hline $\begin{array}{r}\text { Learning } \\
\text { outcomes }\end{array}$ & $\begin{array}{l}\text { Through inquiry, and experimentation using both physical and virtual labs, } \\
\text { students acquire content and concept knowledge on subjects like forces, } \\
\text { motion, Newton's laws, equilibrium, buoyancy, structural stability, modeling, } \\
\text { engineering practices and principles, properties of materials, etc. Through } \\
\text { group work they also improve their social and verbal skills (collaboration, } \\
\text { communication, presentation, project management) and develop key } \\
\text { competencies (creativity, innovative thinking, problem solving, digital literacy). }\end{array}$ \\
\hline
\end{tabular}




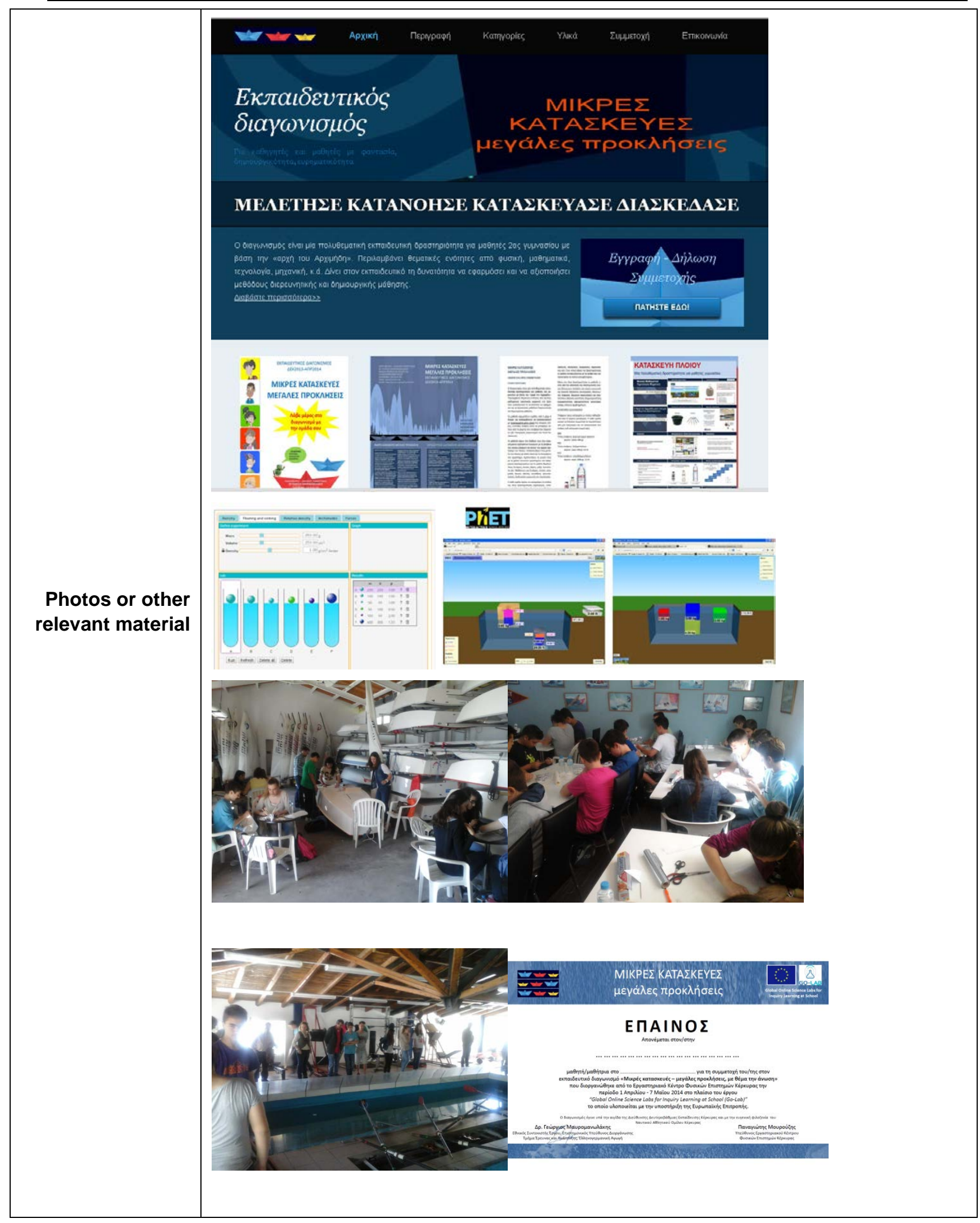




\begin{tabular}{|c|c|}
\hline $\begin{array}{l}\text { G O - L A B } \\
\text { Event Code }\end{array}$ & $\begin{array}{l}\text { GR02-29042014 } \\
\text { GR02-20052014 }\end{array}$ \\
\hline Title & 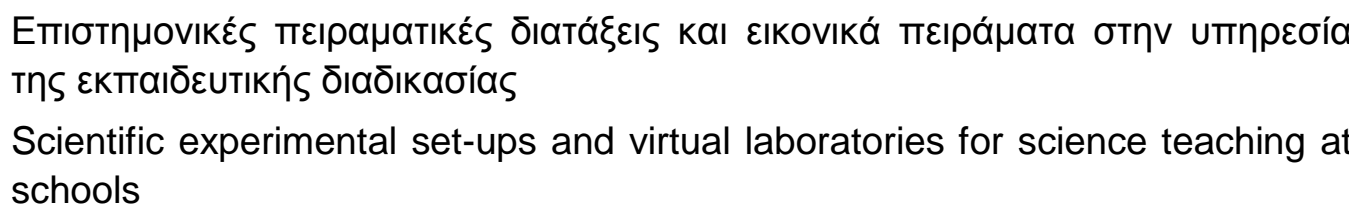 \\
\hline $\begin{array}{r}\text { Country } \\
\text { City/Region }\end{array}$ & Greece, Athens \\
\hline $\begin{array}{l}\text { Working } \\
\text { language }\end{array}$ & Greek \\
\hline Start/End Date & 29/04/2014 and 20/05/2014 \\
\hline $\begin{array}{r}\text { Organizing } \\
\text { Institute }\end{array}$ & EA, IASA \\
\hline $\begin{array}{r}\text { Coordinator } \\
\text { name and email }\end{array}$ & $\begin{array}{l}\text { G. Mavromanolakis } \\
\text { S. Vourakis, C.Kourkoumelis }\end{array}$ \\
\hline Activity Form & Hypatia Training Workshops \\
\hline Activity Type & Local \\
\hline $\begin{array}{l}\text { Total number of } \\
\text { teachers/school }\end{array}$ & $22+24$ teachers $(19+20$ schools $)$ \\
\hline $\begin{array}{r}\text { Implemented } \\
\text { online labs }\end{array}$ & Hypatia lab and related ILSs \\
\hline $\begin{array}{r}\text { Brief } \\
\text { description }\end{array}$ & $\begin{array}{l}\text { Various training workshops for teachers were organized in collaboration with } \\
\text { the Eugenides Foundation which hosted the CERN Exhibition "Accelerating } \\
\text { Science" (co-organized by CERN and EA). On two occasions, on 29/04/2014 } \\
\text { and on 20/05/2014 there were hands-on training workshops on Hypatia lab } \\
\text { and related ILSs (see attached agenda). }\end{array}$ \\
\hline $\begin{array}{l}\text { Learning } \\
\text { outcomes }\end{array}$ & $\begin{array}{l}\text { The participant teachers get an overall idea on the use of online labs in science } \\
\text { teaching, the need for organizing them into a federation and how could Go-Lab } \\
\text { assist them in their teaching by providing, a federation of labs, example } \\
\text { educational activities and supporting tools for their implementation in an } \\
\text { integrated platform. They then practice the use of Hypatia and related Inquiry } \\
\text { Learning Spaces. }\end{array}$ \\
\hline Website & $\begin{array}{l}\text { http://ea.gr/cern } \\
\text { http://ea.gr/cern/workshop_A.pdf }\end{array}$ \\
\hline $\begin{array}{r}\text { Photos or other } \\
\text { relevant } \\
\text { material }\end{array}$ & Announcement/invitation letter and agenda in greek \\
\hline
\end{tabular}




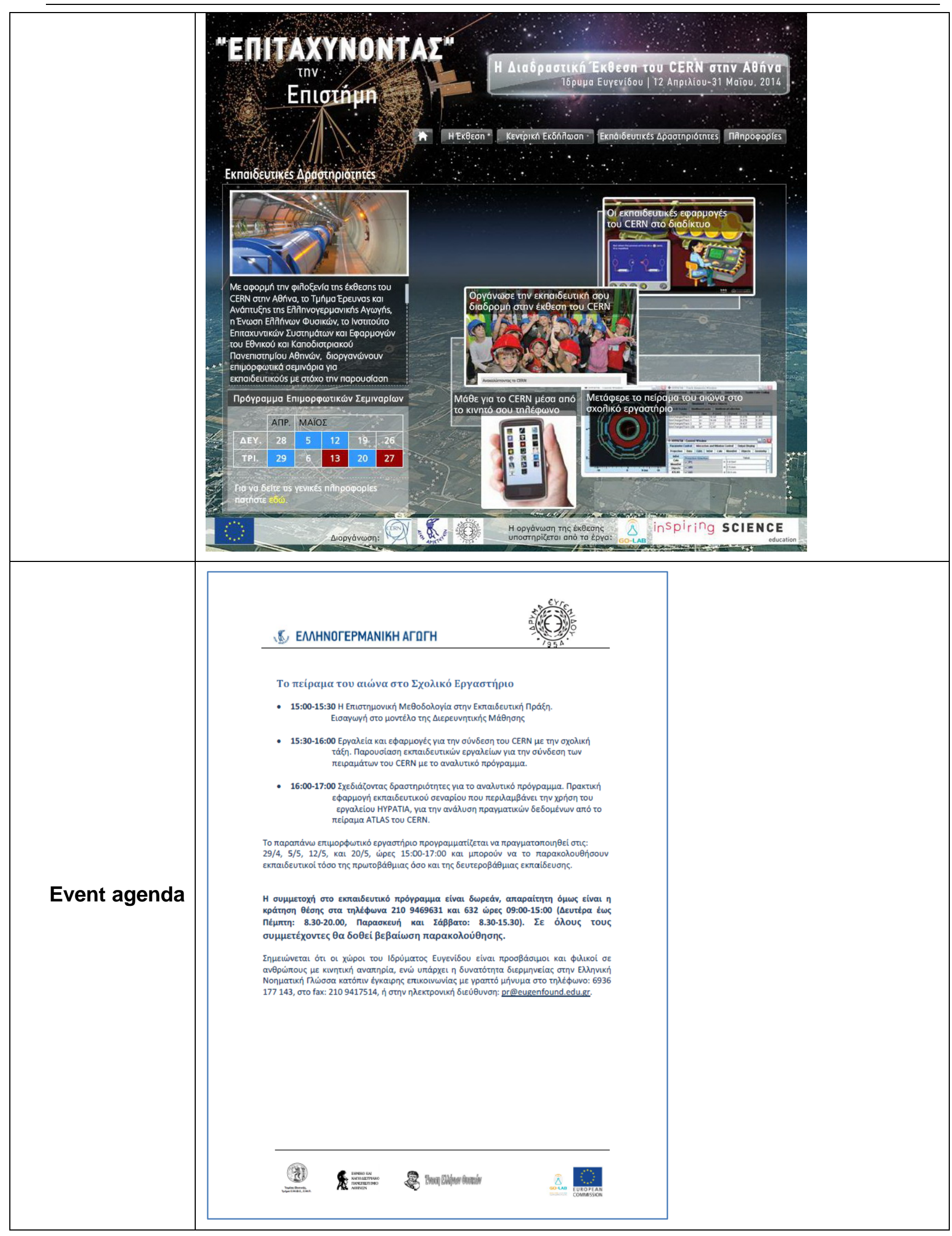




\begin{tabular}{|c|c|}
\hline $\begin{array}{r}\text { G O - L A B } \\
\text { Report Code }\end{array}$ & GR02-09052014 \\
\hline Title & High school students analyze data from particle physics experiment at CERN \\
\hline $\begin{array}{r}\text { Country } \\
\text { City/Region }\end{array}$ & Greece, Glyfada \\
\hline Working language & Greek and English \\
\hline Start/End Date & 09/05/2014 \\
\hline Partners Involved & EA \\
\hline $\begin{array}{r}\text { Coordinator name } \\
\text { and email }\end{array}$ & G.Mavromanolakis gmavroma@ea.gr \\
\hline School Profile & $\begin{array}{l}3^{\text {rd }} \text { junior high-school of Glyfada. It is an urban state school with pioneering } \\
\text { teachers. They have developed innovative STEM teaching e.g educational } \\
\text { robotics and participated in various national science contests for teachers and } \\
\text { students }\end{array}$ \\
\hline $\begin{array}{r}\text { Number and age } \\
\text { of students }\end{array}$ & 42 ( 2 classes) of high school students, age $16-17$ years old \\
\hline $\begin{array}{r}\text { Activity } \\
\text { Description }\end{array}$ & $\begin{array}{l}\text { The educational activity starts with a lecture by G. Mavromanolakis (former } \\
\text { researcher at CERN) on particle physics research, science and technology. } \\
\text { Then students analyze data from the CMS particle physics experiment at the } \\
\text { Large Hadron Collider of CERN using the iSpyCMS online lab (dataset and } \\
\text { event display/analysis tool). }\end{array}$ \\
\hline $\begin{array}{r}\text { Implemented } \\
\text { online labs }\end{array}$ & iSpyCMS (dataset and event display/analysis) \\
\hline $\begin{array}{l}\text { Learning } \\
\text { outcomes }\end{array}$ & $\begin{array}{l}\text { Students get a better understanding how frontier scientific research is } \\
\text { conducted, how cutting edge technologies are developed, what is the everyday } \\
\text { job of researchers, scientists and engineers is in a large international research } \\
\text { center etc. They use real scientific data to investigate and answer a scientific } \\
\text { question. They develop and practice their digital skills by using online } \\
\text { resources and tools. They understand how abstract concepts from their } \\
\text { physics curriculum like the principles of "conservation of energy and } \\
\text { momentum" and "conservation of charge" are applied and manifested in the } \\
\text { microcosmos. }\end{array}$ \\
\hline
\end{tabular}




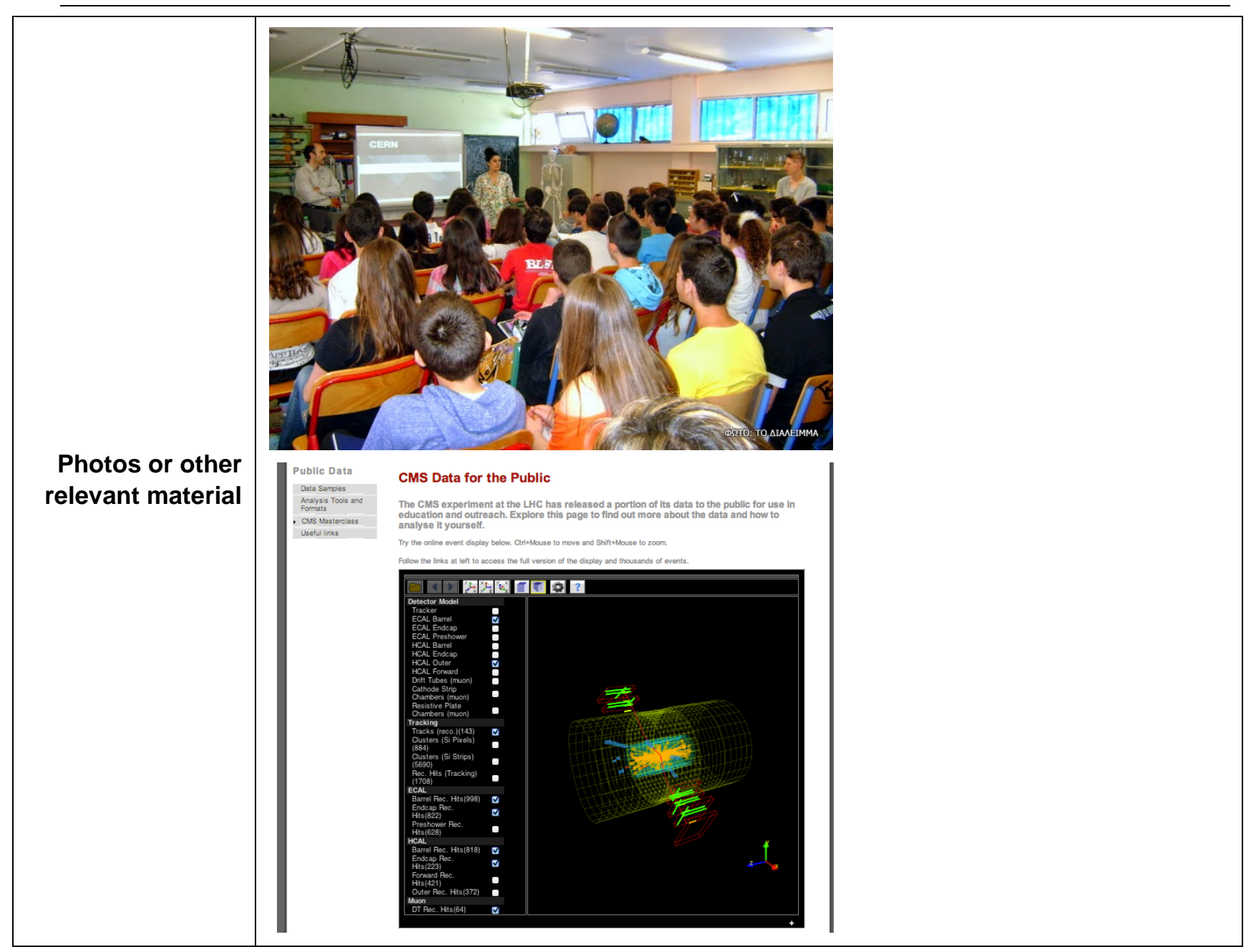




\begin{tabular}{|c|c|c|}
\hline $\begin{array}{r}\text { G O - L A B } \\
\text { Report Code }\end{array}$ & \multicolumn{2}{|l|}{ GR18-100314 } \\
\hline Title & \multicolumn{2}{|c|}{$\begin{array}{l}\text { Workshop on HYPATIA and the ATLAS experiment in Lyceums in the area of } \\
\text { Katerini }\end{array}$} \\
\hline $\begin{array}{r}\text { Country } \\
\text { City/Region }\end{array}$ & \multicolumn{2}{|c|}{ Greece, Katerini } \\
\hline Working language & \multicolumn{2}{|l|}{ Greek } \\
\hline Start/End Date & \multicolumn{2}{|l|}{$10 / 03 / 2014$} \\
\hline Partners Involved & \multicolumn{2}{|l|}{ IASA } \\
\hline $\begin{array}{r}\text { Coordinator name } \\
\text { and email }\end{array}$ & \multicolumn{2}{|c|}{ Christine Kourkoumelis, hkourkou@phys.uoa.gr } \\
\hline $\begin{array}{r}\text { Number and age } \\
\text { of students }\end{array}$ & \multicolumn{2}{|c|}{45 high school students and 8 teachers from 5 schools } \\
\hline $\begin{array}{r}\text { Activity } \\
\text { Description }\end{array}$ & $\begin{array}{l}\text { The objective } \\
\text { the Go-Lab pro } \\
\text { the on-line ev } \\
\text { guided by men } \\
\text { had the opport } \\
\text { Program of th } \\
\text { 9:30-10:30 } \\
\text { 11:00-11:30 } \\
\text { 11:30-13:00 } \\
\text { 13:00 - 14:00 }\end{array}$ & $\begin{array}{l}\text { the mini masterclass was to present the ATLAS experiment, } \\
\text { ct and the Go-Lab repository. The students were introduced to } \\
\text { th analysis tool and performed measurements on their own } \\
\text { ers of the team. They also followed a virtual visit to CERN and } \\
\text { ity to ask questions to the researchers present at CERN. } \\
\text { day: } \\
\text { Introduction to the ATLAS and the new Boson } \\
\text { (C.Kourkoumelis) } \\
\text { Introduction to HYPATIA and he on-line analysis (S.Vourakis) } \\
\text { Hands-on lab at the school's computer lab (S.Vourakis and } \\
\text { G.Vasileiadis) } \\
\text { Virtual Visit to the ATLAS experiment at CERN (in connection } \\
\text { with } 11 \text { other schools from all over Greece) }\end{array}$ \\
\hline $\begin{array}{r}\text { Implemented } \\
\text { online labs }\end{array}$ & \multicolumn{2}{|c|}{ HYPATIA lab and ILSs } \\
\hline $\begin{array}{l}\text { Learning } \\
\text { outcomes }\end{array}$ & \multicolumn{2}{|c|}{$\begin{array}{ll}\text { - } & \text { Acquaintance with the Go-Lab project } \\
\text { - } & \text { Familiarization with Go-Lab ILSs and online labs } \\
\text { - } & \text { Familiarization with the HYPATIA event analysis tool }\end{array}$} \\
\hline
\end{tabular}




\begin{tabular}{|c|c|}
\hline $\begin{array}{l}\text { G O - L A B } \\
\text { Event Code }\end{array}$ & [GR02-130714] \\
\hline Title & International Science Teachers Training Course \\
\hline $\begin{array}{r}\text { Country } \\
\text { City/Region }\end{array}$ & Marathon, Greece \\
\hline Working language & English \\
\hline Start/End Date & $13 / 07 / 2014-18 / 07 / 2014$ \\
\hline $\begin{array}{r}\text { Organizing } \\
\text { Institute }\end{array}$ & Ellinogermaniki Agogi \\
\hline $\begin{array}{r}\text { Coordinator name } \\
\text { and email }\end{array}$ & $\begin{array}{l}\text { Tsourlidaki Eleftheria eleftheria@ea.gr } \\
\text { Mavromanolakis Georgios gmavroma@ea.gr } \\
\text { Sofoklis Sotiriou sotiriou@ea.gr }\end{array}$ \\
\hline $\begin{array}{r}\text { Go-Lab Partners } \\
\text { that were also } \\
\text { Involved }\end{array}$ & $\begin{array}{l}\text { Adrian Holzer (EPFL) } \\
\text { Matthias Heintz (ULEIC) } \\
\text { Rob Edlin White (ULEIC) } \\
\text { Frawer Lewis (UOG) } \\
\text { Gina Mihai (EUN) } \\
\text { Urmas Heinste (UTE) } \\
\text { Leo Siiman (UTE) } \\
\text { Chiristine Kourkoumelis (IASA) } \\
\text { Rosa Doran (NUCLIO) } \\
\text { Alexandros Trichos (CERTH) } \\
\text { Vassilis Fasoulis (MENON) }\end{array}$ \\
\hline Activity Form & Summer School \\
\hline Activity Type & International \\
\hline $\begin{array}{l}\text { Total number of } \\
\text { teachers/schools }\end{array}$ & $39 / 38$ \\
\hline $\begin{array}{l}\text { Implemented } \\
\text { online labs }\end{array}$ & $\begin{array}{l}\text { Faulkes Telescopes } \\
\text { Crashing Galaxies } \\
\text { SalsaJ } \\
\text { Craters on Earth and Other Planets } \\
\text { Electricity lab } \\
\text { Splash: Virtual Buoyancy Laboratory } \\
\text { HYPATIA }\end{array}$ \\
\hline Brief description & $\begin{array}{l}\text { Summer School for introducing to teachers the IBSE teaching approach and } \\
\text { the use of on-line labs. }\end{array}$ \\
\hline
\end{tabular}




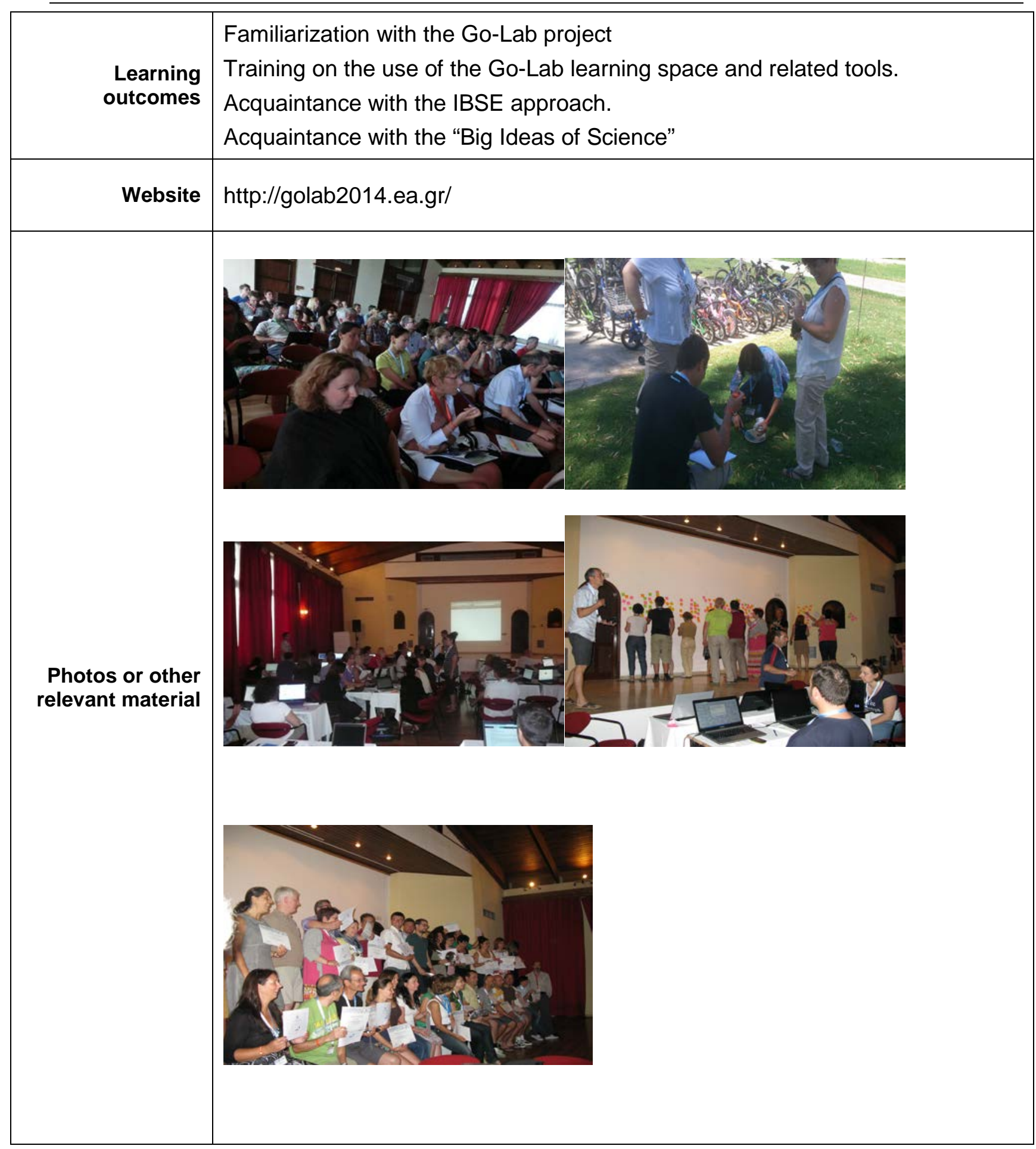




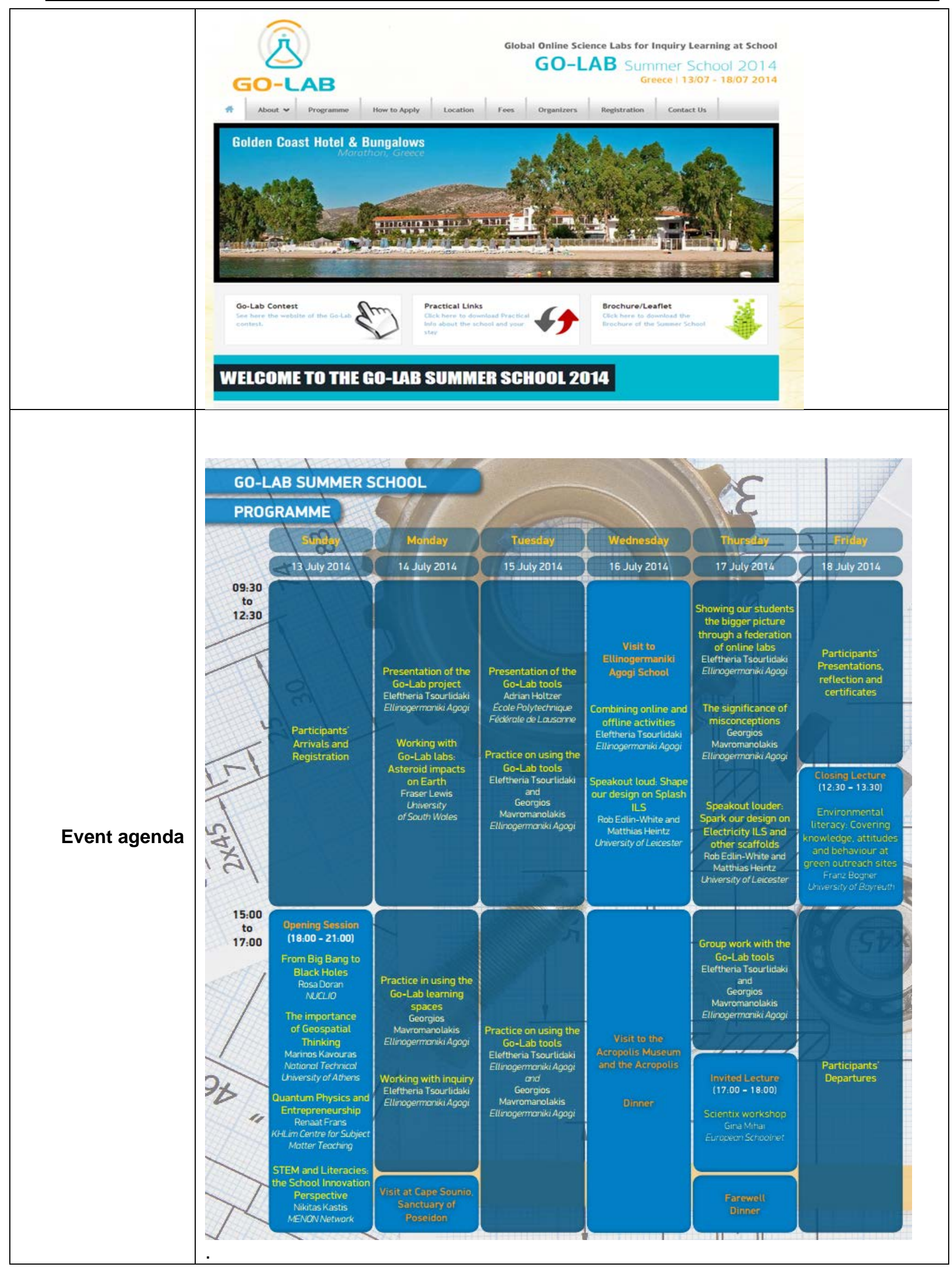




\subsection{The Netherlands}

UT is the national coordinator of implementation in the Netherlands. It is also the lab provider/owner of several online virtual labs for inquiry teaching, such as Splash and Electricity lab. During Phase-A it organized 6 activities with 4 schools where 230 students participated. The focus was on physics curriculum utilizing the Splash and Electricity labs and the associated ILSs.

\begin{tabular}{|l|l|l|l|l|}
\hline Date(s) & Type & Participants (Schools) & Labs & Subject(s) \\
\hline $\begin{array}{l}24 / 03 / 2014 \\
25 / 03 / 2014\end{array}$ & $\begin{array}{l}\text { Activity with } \\
\text { students }\end{array}$ & $27(1)$ & Splash & Physics \\
\hline $\begin{array}{l}14 / 04 / 2014 \\
23 / 04 / 2014\end{array}$ & $\begin{array}{l}\text { Activity with } \\
\text { students }\end{array}$ & $90(1)$ & Splash & Physics \\
\hline $\begin{array}{l}15 / 05 / 2014 \\
28 / 05 / 2014\end{array}$ & $\begin{array}{l}\text { Activity with } \\
\text { students }\end{array}$ & $60(1)$ & Splash & Physics \\
\hline $\begin{array}{l}23 / 06 / 2014 \\
27 / 06 / 2014\end{array}$ & $\begin{array}{l}\text { Activity with } \\
\text { students }\end{array}$ & $53(1)$ & Electricity lab & Physics \\
\hline
\end{tabular}

In the following the detailed reports from the activities are shown. 


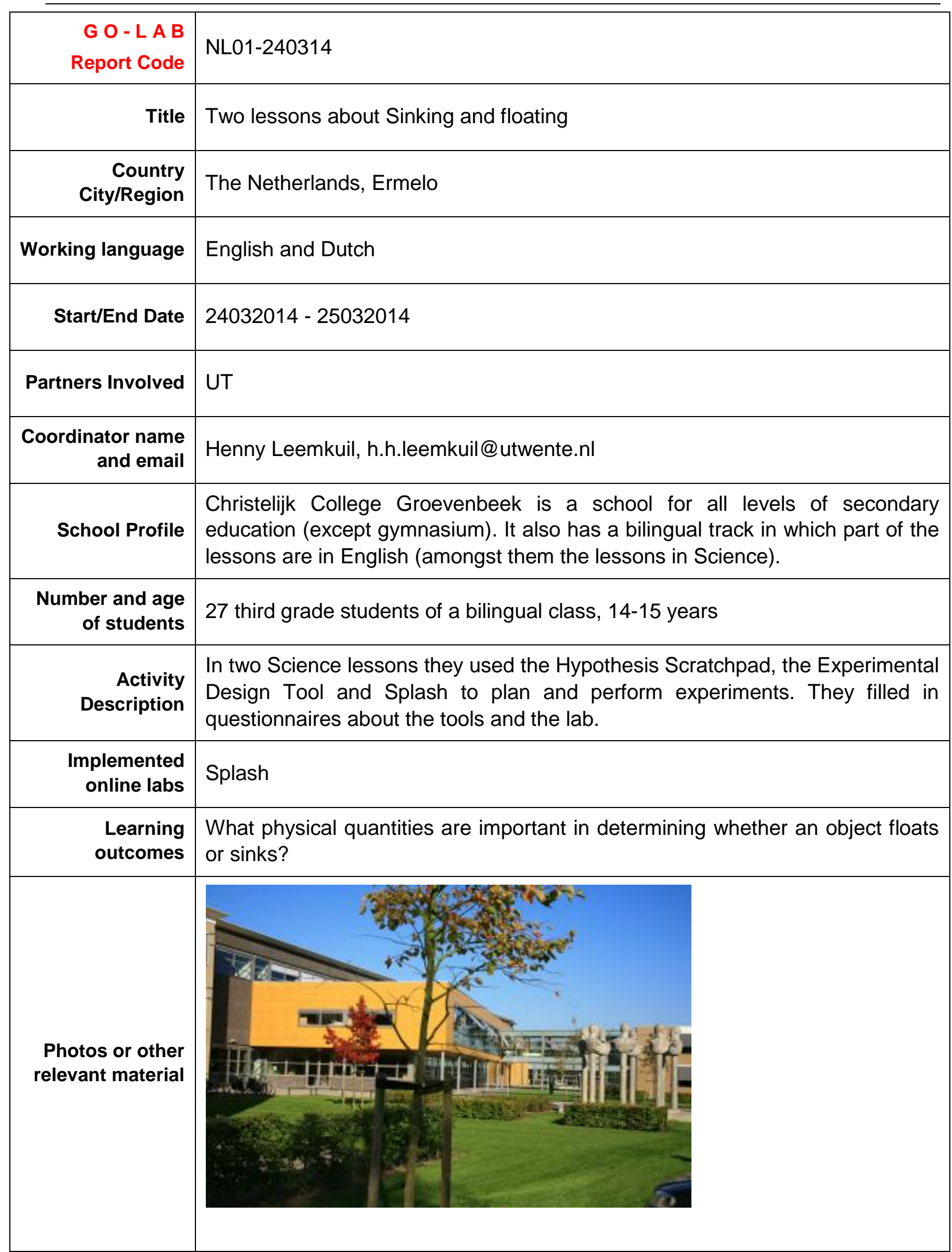




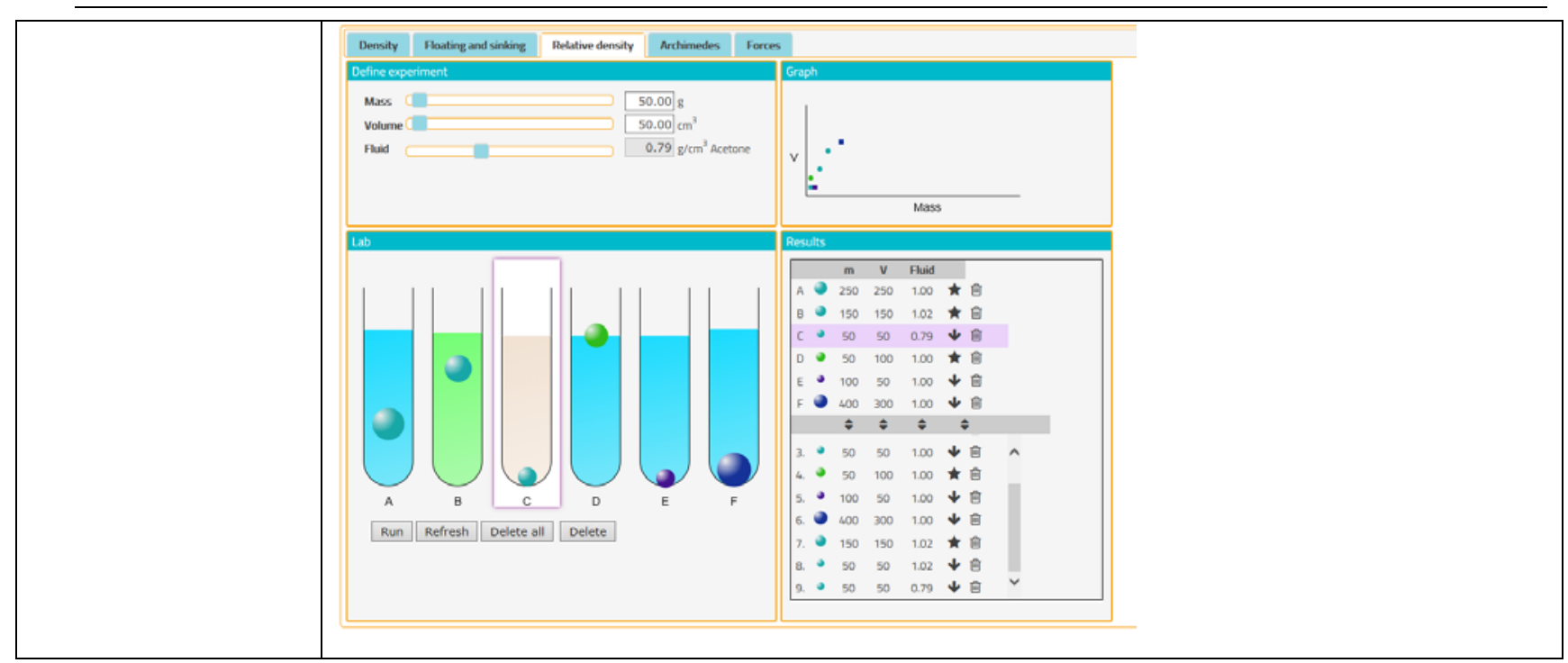




\begin{tabular}{|c|c|}
\hline $\begin{array}{r}\text { G O - L A B } \\
\text { Report Code }\end{array}$ & [NL01-14042014] \\
\hline Title & Siswa's experiment 1 \\
\hline $\begin{array}{r}\text { Country } \\
\text { City/Region }\end{array}$ & The Netherlands, Hengelo \\
\hline Working language & Dutch \\
\hline Start/End Date & $14042014-23042014$ \\
\hline Partners Involved & UT \\
\hline $\begin{array}{r}\text { Coordinator name } \\
\text { and email }\end{array}$ & Henny Leemkuil, h.h.leemkuil@utwente.nl \\
\hline School Profile & $\begin{array}{l}\text { Lyceum de Grundel is a school for the higher levels of secondary education } \\
\text { (havo, atheneum and gymnasium). Except for the traditional subjects there is } \\
\text { an examination subject "Nature, life and technology". There is also a lot of } \\
\text { attention for Science in the curriculum. }\end{array}$ \\
\hline $\begin{array}{r}\text { Number and age } \\
\text { of students }\end{array}$ & 3 classes, about 90 students in total, 3th year, age 14-15 \\
\hline $\begin{array}{r}\text { Activity } \\
\text { Description }\end{array}$ & $\begin{array}{l}4 \text { lessons. In the first lesson students the students got a pretest on the subject } \\
\text { of buoyancy. In the following two lessons they planned and conducted } \\
\text { experiments using the EDT and Splash. In the fourth lesson the students got a } \\
\text { posttest. }\end{array}$ \\
\hline $\begin{array}{r}\text { Implemented } \\
\text { online labs }\end{array}$ & Splash \\
\hline $\begin{array}{l}\text { Learning } \\
\text { outcomes }\end{array}$ & $\begin{array}{l}\text { This lab consists of four learning phases in which students discover (1) the } \\
\text { relationship between mass, volume and density, ( } 2 \text { ) the relationship between } \\
\text { densities of different solids and fluids, ( } 3 \text { ) properties that affect the floating or } \\
\text { sinking of objects, and (4) Archimedes' principle }\end{array}$ \\
\hline $\begin{array}{l}\text { Photos or other } \\
\text { relevant material }\end{array}$ & UNDEL \\
\hline
\end{tabular}




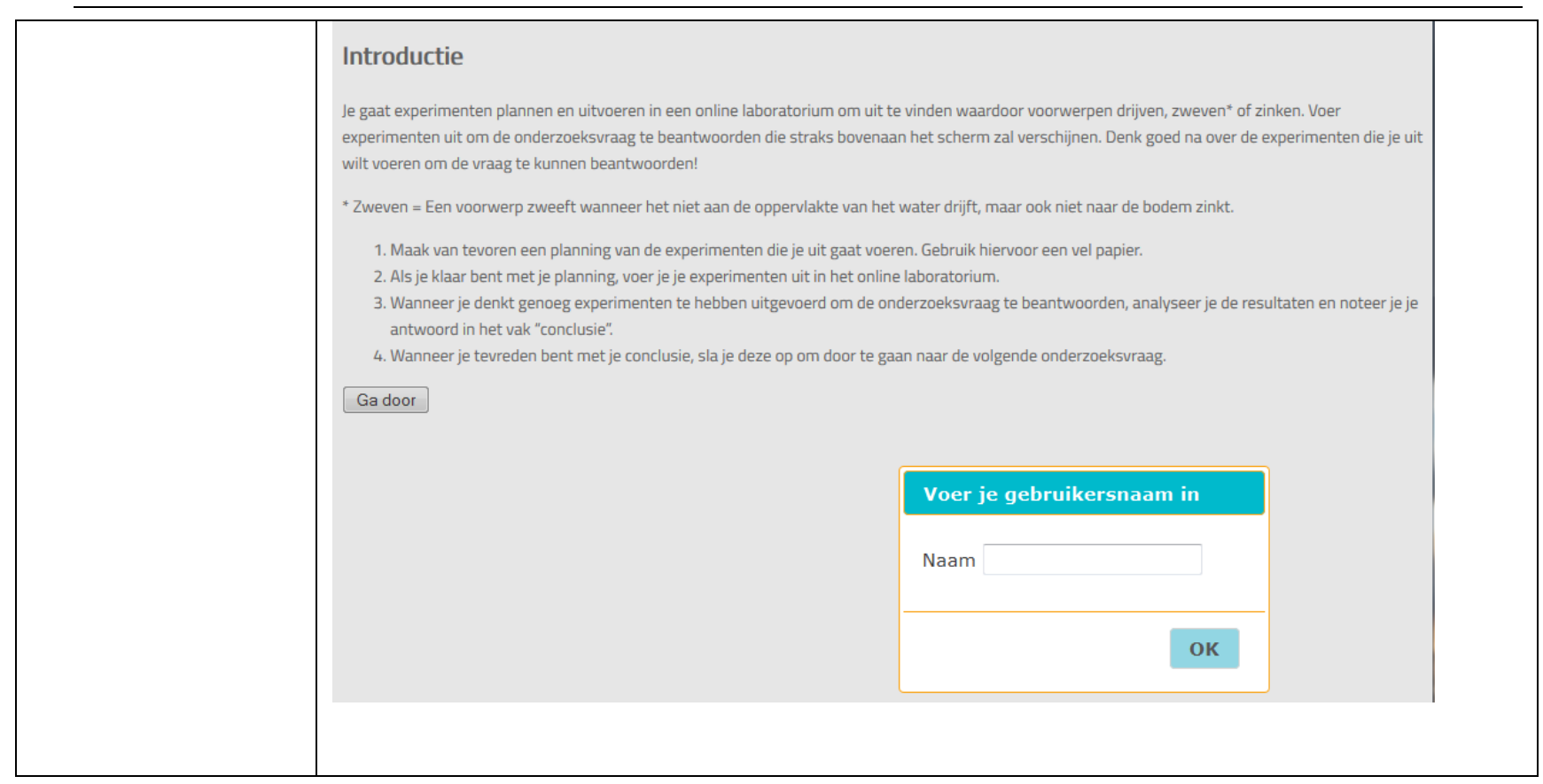




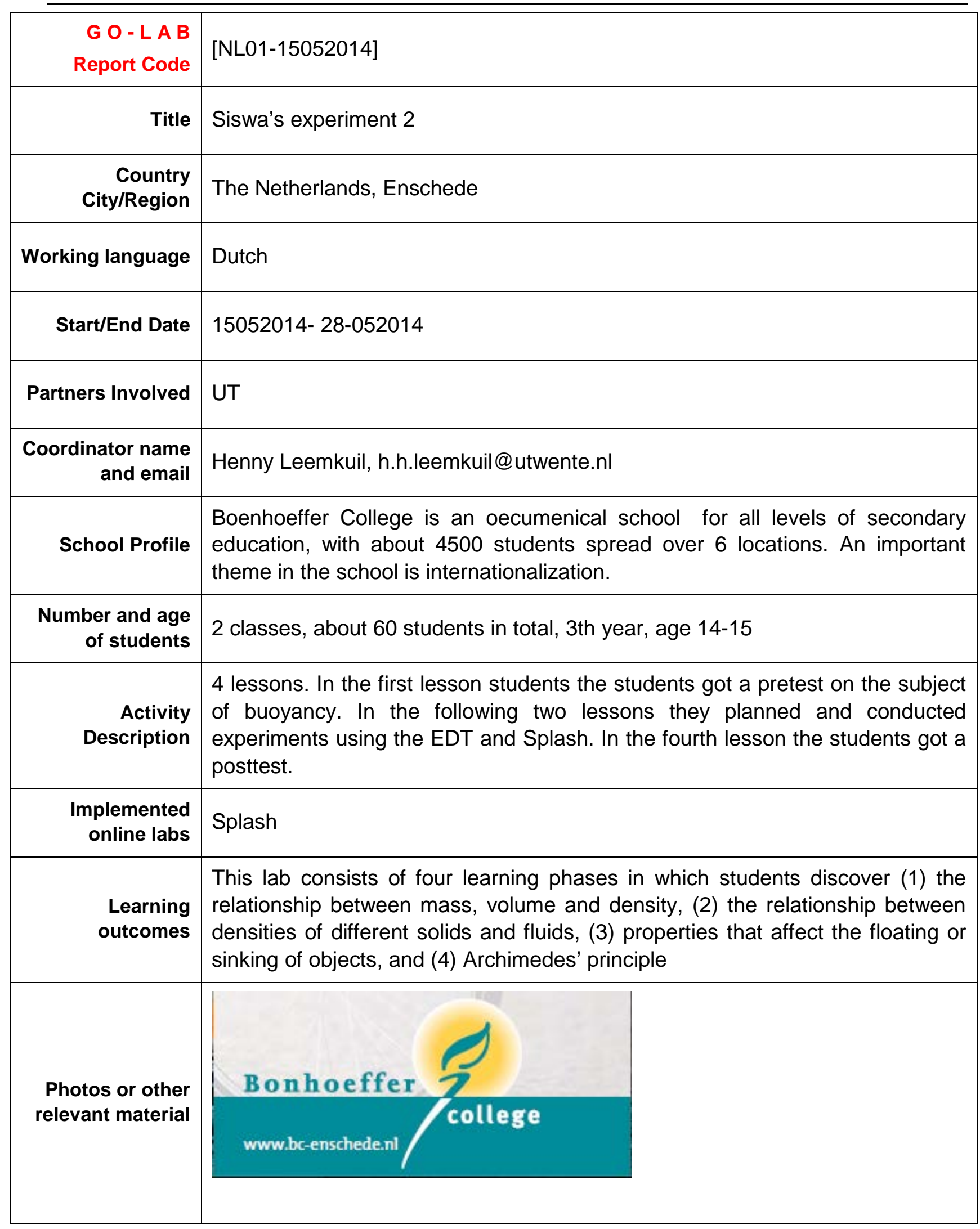




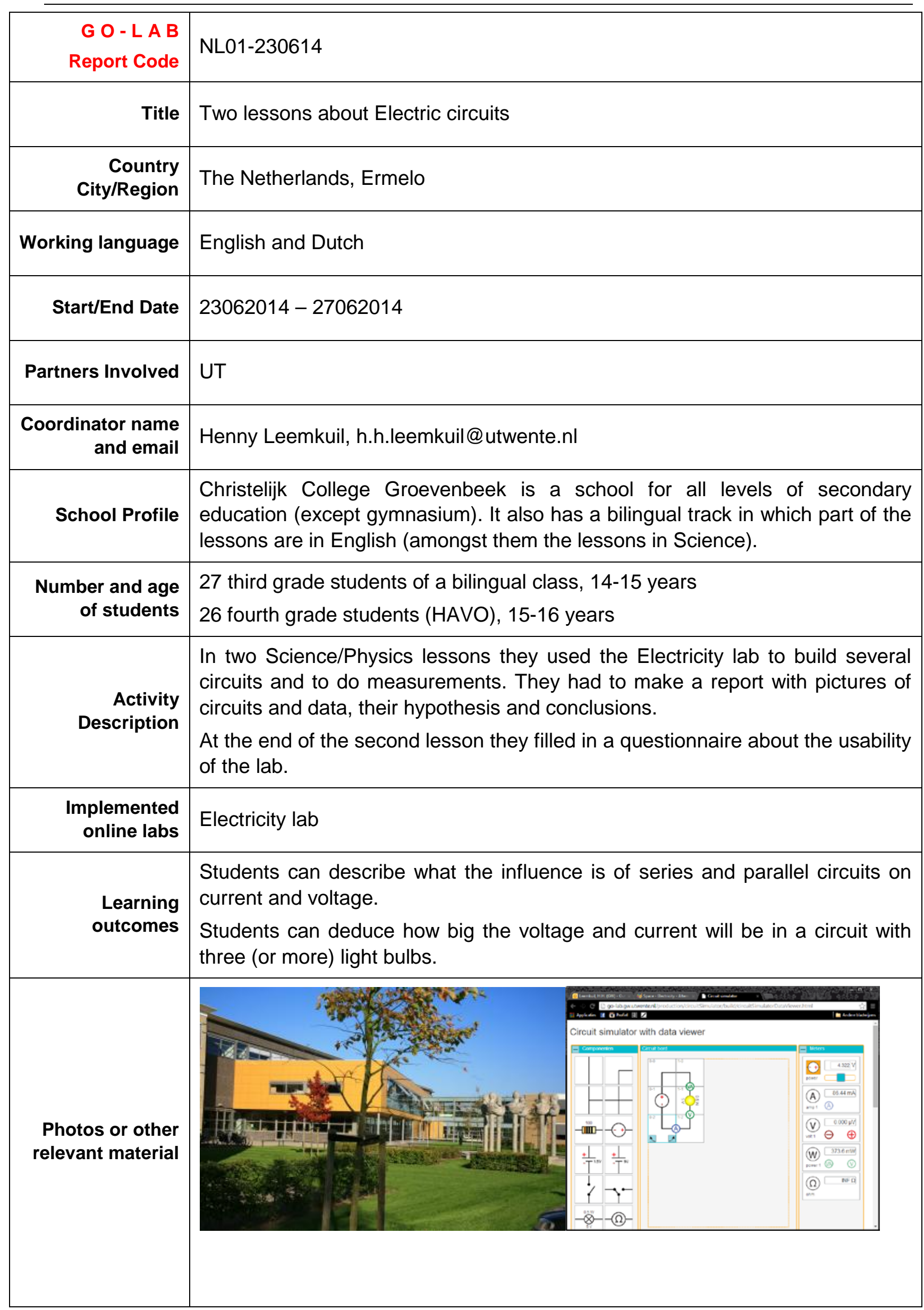




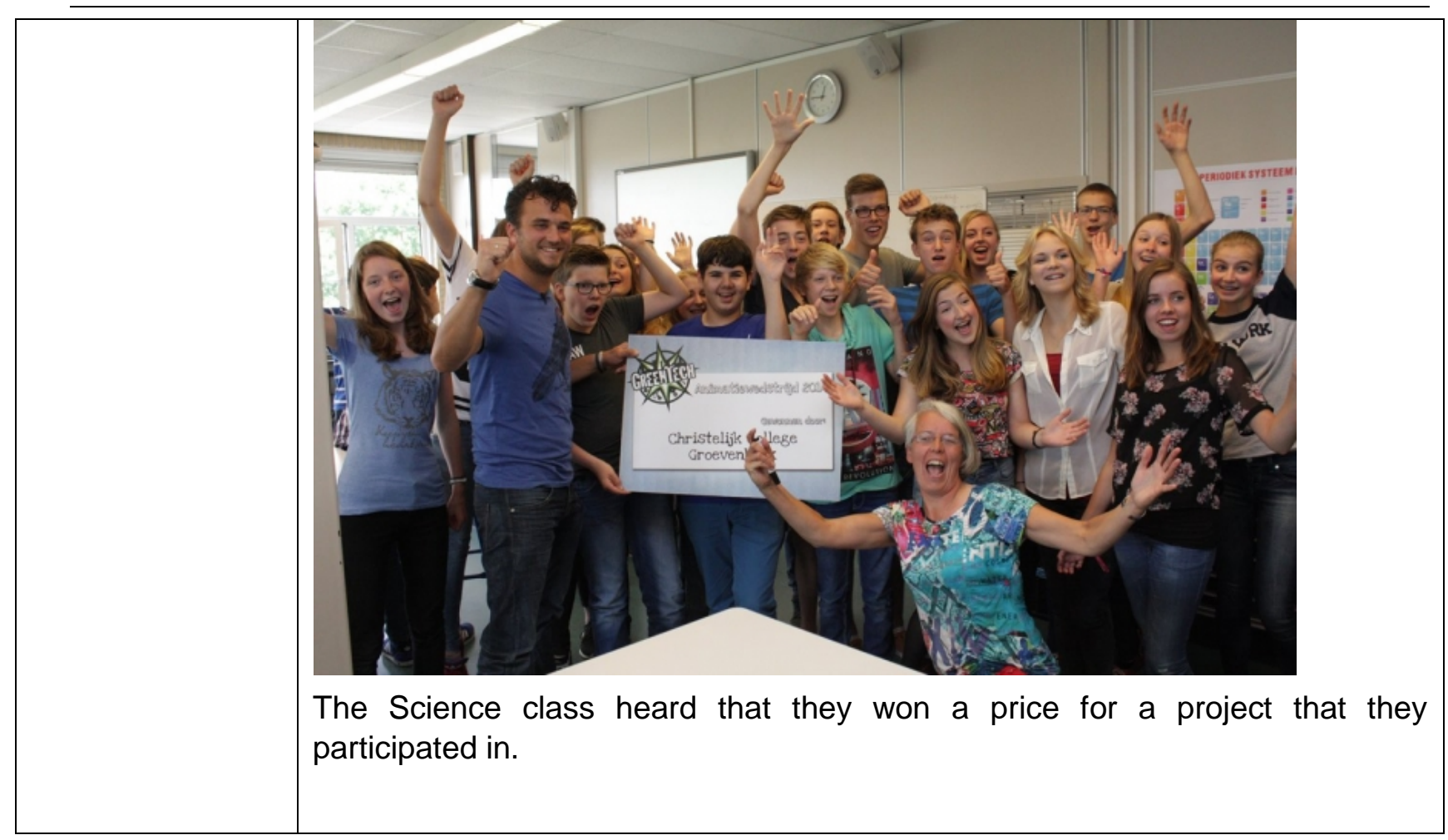




\subsection{Portugal}

NUCLIO is the national coordinator of implementation in Portugal. During Phase-A it conducted 5 training workshops with 75 teachers from 17 secondary schools focusing on physics and astronomy curricula utilizing SalsaJ, Sun4all, and Faulkes remote telescopes (see list below). In the period prior and during Phase-A NUCLIO also organized series of demonstration events, socalled Go-Lab demos, in the framework of the Galileo Teachers Training Programme reaching a large audience of teachers and students. These events are facilitating the uptake of Go-Lab by science teachers and secondary schools in Portugal and beyond.

\begin{tabular}{|l|l|l|l|l|}
\hline Date(s) & Type & $\begin{array}{l}\text { Participants } \\
\text { (Schools) }\end{array}$ & Labs & Subject(s) \\
\hline $07 / 01 / 2014$ & $\begin{array}{l}\text { Training of } \\
\text { teachers }\end{array}$ & $20(20)$ & $\begin{array}{l}\text { Salsa J, Sun4all, Faulkes } \\
\text { Telescope }\end{array}$ & $\begin{array}{l}\text { Physics, } \\
\text { Astronomy }\end{array}$ \\
\hline $21 / 03 / 2014$ & $\begin{array}{l}\text { Training of } \\
\text { teachers }\end{array}$ & $20(20)$ & $\begin{array}{l}\text { Salsa J, Sun4all, Faulkes } \\
\text { Telescope }\end{array}$ & $\begin{array}{l}\text { Physics, } \\
\text { Astronomy }\end{array}$ \\
\hline $04 / 05 / 2014$ & $\begin{array}{l}\text { Training of } \\
\text { teachers }\end{array}$ & $30(30)$ & Salsa J, Impact calculator & $\begin{array}{l}\text { Physics, } \\
\text { Astronomy }\end{array}$ \\
\hline $\begin{array}{l}\text { 22/05/2014 - } \\
30 / 06 / 2014\end{array}$ & $\begin{array}{l}\text { Training of } \\
\text { teachers }\end{array}$ & $5(1)$ & Salsa J, Faulkes Telescope & $\begin{array}{l}\text { Physics, } \\
\text { Astronomy }\end{array}$ \\
\hline
\end{tabular}

In the following the reports from all the conducted activities are shown. 


\begin{tabular}{|c|c|}
\hline $\begin{array}{r}\text { G O - L A B } \\
\text { Report Code }\end{array}$ & PT19070114 \\
\hline Title & Astronomia Hands-on (Astronomy Hands-on) \\
\hline $\begin{array}{r}\text { Country } \\
\text { City/Region }\end{array}$ & Portugal - Madeira Island \\
\hline Working language & Portuguese \\
\hline Start/End Date & 07/01/2014 - 14/01/2014 \\
\hline Partners Involved & NUCLIO \\
\hline $\begin{array}{r}\text { Coordinator name } \\
\text { and email }\end{array}$ & Rosa Doran / rosa.doran@nuclio.pt \\
\hline $\begin{array}{l}\text { Total number of } \\
\text { teachers/schools }\end{array}$ & 20 participants (Mathematics, Natural Sciences and Physcis) \\
\hline $\begin{array}{r}\text { Activity } \\
\text { Description }\end{array}$ & $\begin{array}{l}\text { This is a certified training promoting the use of modern tools and resources for } \\
\text { science education. Several Go-lab tools are presented. An entire section is } \\
\text { devoted to IBSE. }\end{array}$ \\
\hline $\begin{array}{l}\text { Implemented } \\
\text { online labs }\end{array}$ & $\begin{array}{l}\text { Salsa J, Sun4all, Faulkes Telescope. Other virtual labs are also presented } \\
\text { (Stellarium, Celestia, Google Earth and WWT) }\end{array}$ \\
\hline $\begin{array}{r}\text { Learning } \\
\text { outcomes }\end{array}$ & $\begin{array}{l}\text { The theme of big ideas was introduced and the tools and resources promoting } \\
\text { them presented. The main purpose of this part of the training is to promote the } \\
\text { interest of the teaches to collaborate between subject areas, grade levels and } \\
\text { and as far as possible using a contextualized approach }\end{array}$ \\
\hline $\begin{array}{l}\text { Photos or other } \\
\text { relevant material }\end{array}$ & $\begin{array}{l}\text { https://www.facebook.com/media/set/?set=a.796217353728614.1073741854.1 } \\
\text { 30639500286406\&type=3 }\end{array}$ \\
\hline
\end{tabular}




\begin{tabular}{|c|c|}
\hline $\begin{array}{l}\text { G O - L A B } \\
\text { Report Code }\end{array}$ & PT19210314 \\
\hline Title & Astronomia Hands-on (Astronomy Hands-on) \\
\hline $\begin{array}{r}\text { Country } \\
\text { City/Region }\end{array}$ & Portugal - Caldas da Rainha \\
\hline Working language & Portuguese \\
\hline Start/End Date & 21/03/2014 \\
\hline Partners Involved & NUCLIO \\
\hline $\begin{array}{r}\text { Coordinator name } \\
\text { and email }\end{array}$ & Rosa Doran / rosa.doran@nuclio.pt \\
\hline $\begin{array}{l}\text { Total number of } \\
\text { teachers/schools }\end{array}$ & 20 participants(Mathematics, Natural Sciences, Chemistry and Physcis) \\
\hline $\begin{array}{r}\text { Activity } \\
\text { Description }\end{array}$ & $\begin{array}{l}\text { This is a certified training promoting the use of modern tools and resources for } \\
\text { science education. An entire section is devoted to IBSE. The use of remote } \\
\text { and virtual labs was introduced }\end{array}$ \\
\hline $\begin{array}{l}\text { Implemented } \\
\text { online labs }\end{array}$ & $\begin{array}{l}\text { Salsa J, Sun4all, Faulkes Telescope. Other virtual labs are also presented } \\
\text { (Stellarium, Celestia, Google Earth and WWT) }\end{array}$ \\
\hline $\begin{array}{l}\text { Learning } \\
\text { outcomes }\end{array}$ & $\begin{array}{l}\text { The main goal was to overcome the barriers towards the uptake of modern } \\
\text { tools for science education and the adpotion of IBSE. }\end{array}$ \\
\hline $\begin{array}{l}\text { Photos or other } \\
\text { relevant material }\end{array}$ & $\begin{array}{l}\text { https://www.facebook.com/media/set/?set=a.881967808486901.1073741870.1 } \\
\text { 30639500286406\&type=3 }\end{array}$ \\
\hline
\end{tabular}




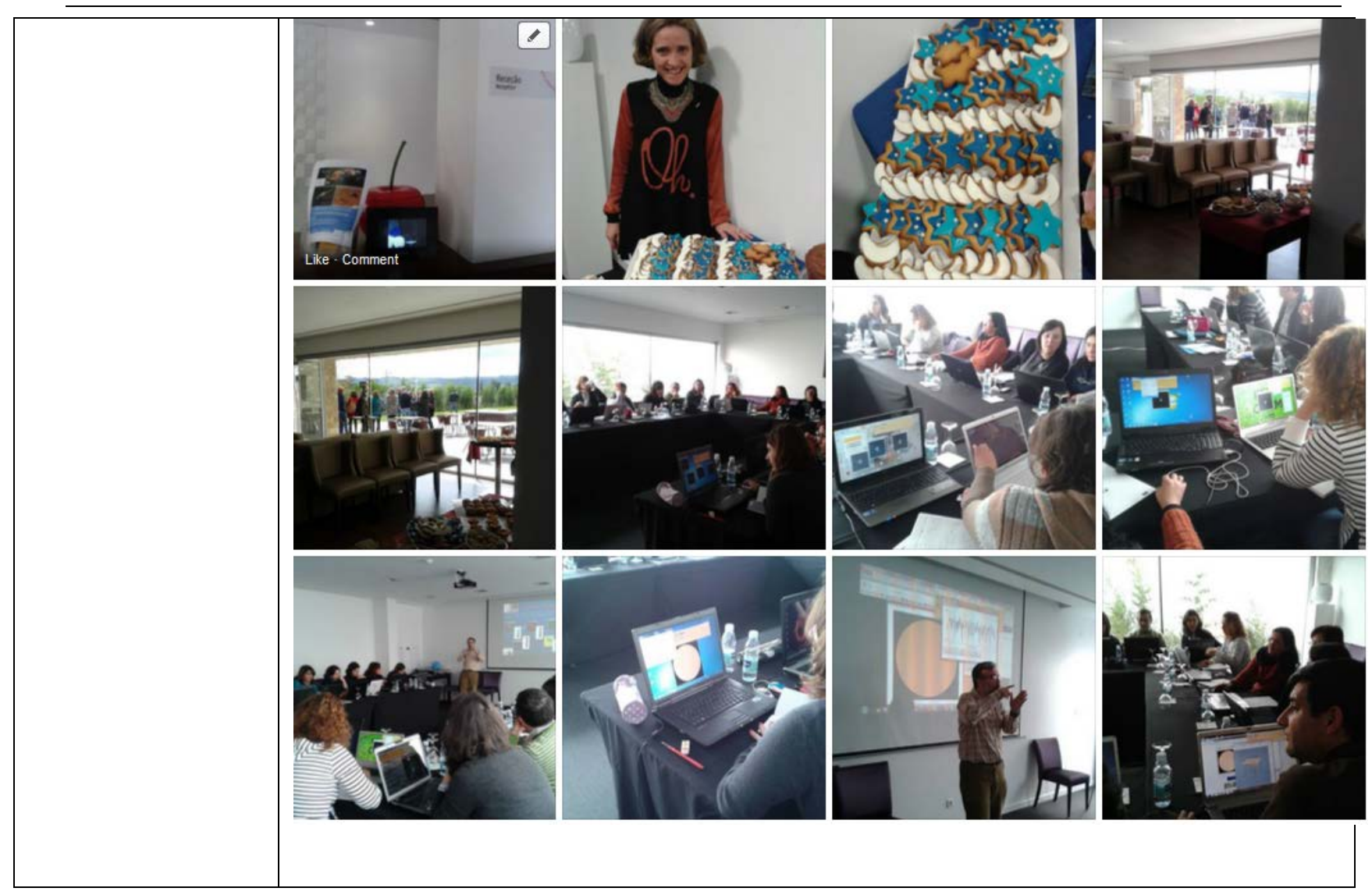




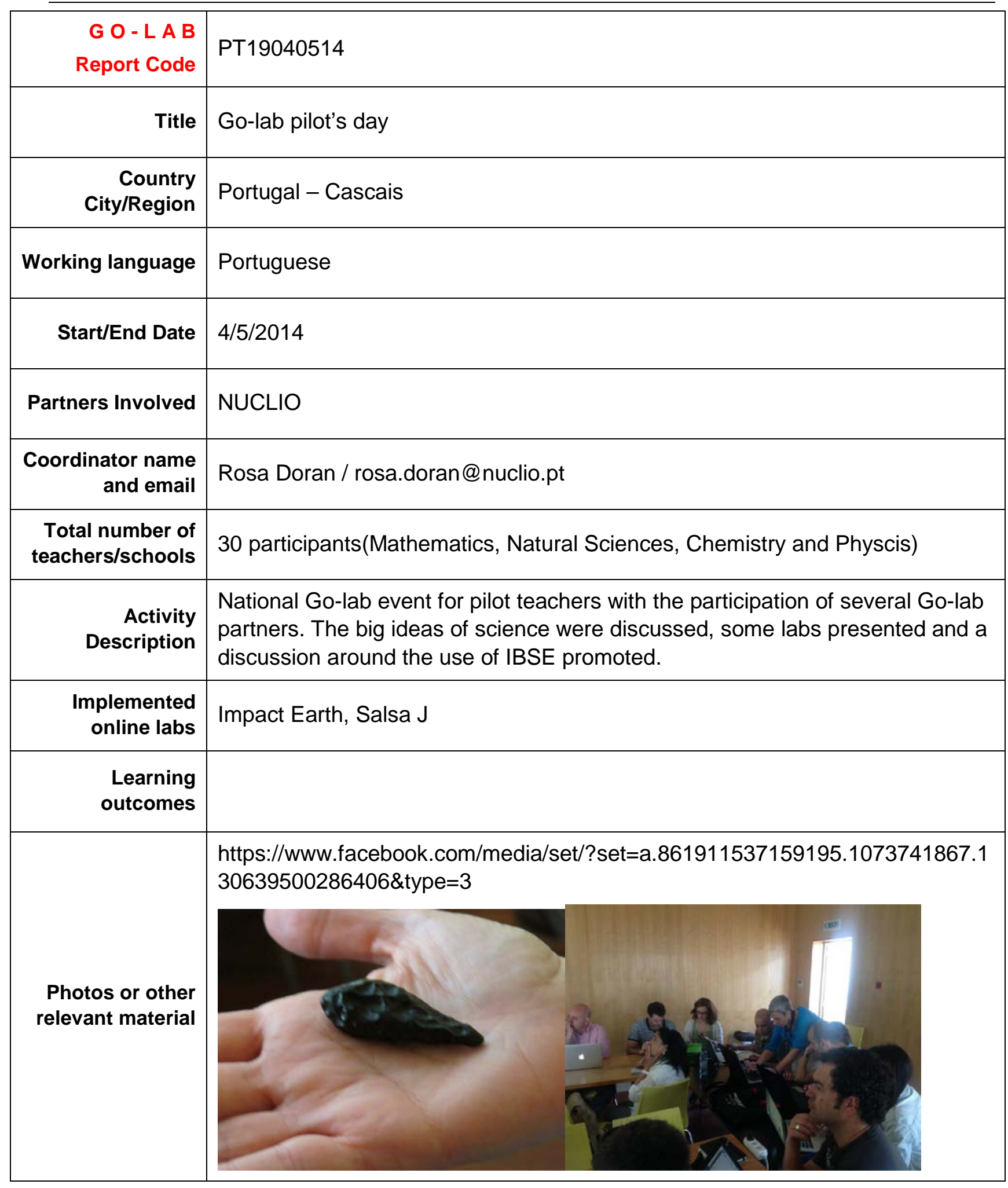




\begin{tabular}{|c|c|}
\hline $\begin{array}{r}\text { G O - L A B } \\
\text { Report Code }\end{array}$ & PT19220514 \\
\hline Title & Go-lab in Libraries Fun Corner \\
\hline $\begin{array}{r}\text { Country } \\
\text { City/Region }\end{array}$ & Cascais - Portugal \\
\hline Working language & Portuguese \\
\hline Start/End Date & $22 / 05 / 2014-30 / 06 / 2014$ \\
\hline Partners Involved & NUCLIO \\
\hline $\begin{array}{r}\text { Coordinator name } \\
\text { and email }\end{array}$ & Rosa Doran / rosa.doran@nuclio.pt \\
\hline $\begin{array}{l}\text { Total number of } \\
\text { teachers/schools }\end{array}$ & 5 library activity promoters \\
\hline $\begin{array}{r}\text { Activity } \\
\text { Description }\end{array}$ & Training on the use of IBSE methodology and a selection of labs \\
\hline $\begin{array}{r}\text { Implemented } \\
\text { online labs }\end{array}$ & Faulkes Telescope, Stellarium and Salsa J \\
\hline $\begin{array}{l}\text { Learning } \\
\text { outcomes }\end{array}$ & $\begin{array}{l}\text { This libraries promote afterschool activities to children in disadvantage areas. } \\
\text { The idea is to sparkle their interest for science through the involvement of } \\
\text { science experiences in the field of astronomy }\end{array}$ \\
\hline $\begin{array}{l}\text { Photos or other } \\
\text { relevant material }\end{array}$ & \\
\hline
\end{tabular}




\begin{tabular}{|c|c|}
\hline $\begin{array}{r}\text { G O - L A B } \\
\text { Report Code }\end{array}$ & PT19310714 \\
\hline Title & Go-lab Demos at School - NUCLIO on the road \\
\hline $\begin{array}{r}\text { Country } \\
\text { City/Region }\end{array}$ & $\begin{array}{l}\text { Portugal - Vila Real, Lisbon, Setubal, Porto, Oeiras, Cascais, Via Longa, } \\
\text { PAlmela } \\
\text { Vila Nova Barquinha, S.J.Madeira, Sesimbra, }\end{array}$ \\
\hline Working language & Portuguese \\
\hline Start/End Date & Jan 2014 - July 2014 \\
\hline Partners Involved & NUCLIO \\
\hline $\begin{array}{r}\text { Coordinator name } \\
\text { and email }\end{array}$ & Rosa Doran / rosa.doran@nuclio.pt \\
\hline $\begin{array}{l}\text { Total number of } \\
\text { teachers/schools }\end{array}$ & 215 teachers and 2120 participants from middle and high school in 27 events \\
\hline $\begin{array}{r}\text { Activity } \\
\text { Description }\end{array}$ & $\begin{array}{l}\text { Demo activities in school where a modern topic of astronomy introduced, } \\
\text { workshops for students on the use of digital tools and virtual labs and a } \\
\text { workshop for teachers introducing the project. }\end{array}$ \\
\hline $\begin{array}{r}\text { Implemented } \\
\text { online labs }\end{array}$ & $\begin{array}{l}\text { Salsa J, Sun4all, Faulkes Telescope. Other virtual labs are also presented } \\
\text { (Stellarium, Celestia, Google Earth and WWT) }\end{array}$ \\
\hline $\begin{array}{l}\text { Learning } \\
\text { outcomes }\end{array}$ & $\begin{array}{l}\text { The main goal was to overcome the barriers towards the uptake of modern } \\
\text { tools for science education and the adoption of IBSE. }\end{array}$ \\
\hline $\begin{array}{l}\text { Photos or other } \\
\text { relevant material }\end{array}$ & 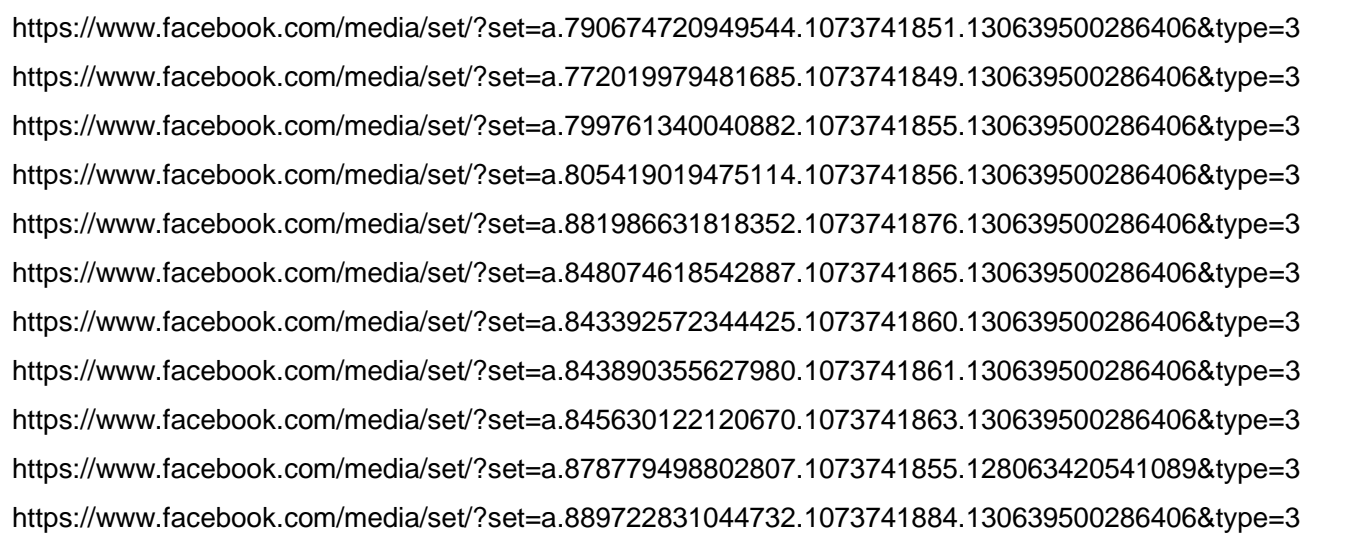 \\
\hline
\end{tabular}




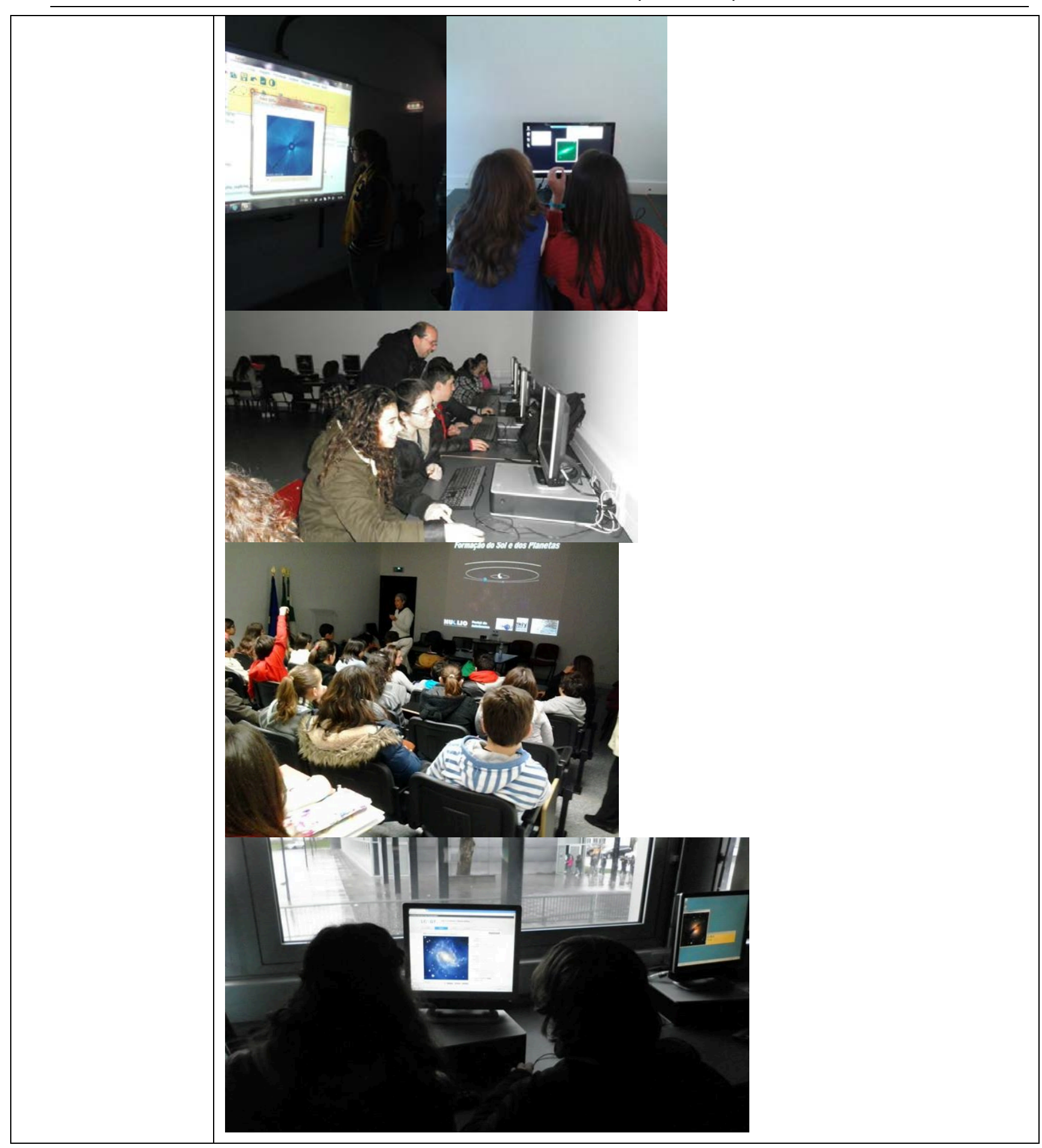




\begin{tabular}{|c|c|}
\hline $\begin{array}{r}\text { G O - L A B } \\
\text { Report Code }\end{array}$ & PT19040513 \\
\hline Title & Universo Invisível (Invisible Universe) \\
\hline $\begin{array}{r}\text { Country } \\
\text { City/Region }\end{array}$ & Portugal - Aveiro \\
\hline Working language & Portuguese \\
\hline Start/End Date & 04-05-2013 / 08-06-2013 \\
\hline Partners Involved & NUCLIO \\
\hline $\begin{array}{r}\text { Coordinator name } \\
\text { and email }\end{array}$ & Rosa Doran / rosa.doran@nuclio.pt \\
\hline $\begin{array}{l}\text { Total number of } \\
\text { teachers/schools }\end{array}$ & 20 participants (Mathematics, Natural Sciences and Physcis) \\
\hline $\begin{array}{r}\text { Activity } \\
\text { Description }\end{array}$ & $\begin{array}{l}\text { This is a certified training promoting the use of modern tools and resources for } \\
\text { science education introducing remote labs (radio antenas and robotic } \\
\text { telescopes). Several Go-lab tools are presented. The methodology of IBSE } \\
\text { was discussed and examples of the integration of its use with the tools were } \\
\text { discusses }\end{array}$ \\
\hline $\begin{array}{r}\text { Implemented } \\
\text { online labs }\end{array}$ & $\begin{array}{l}\text { Salsa J, Sun4all, Faulkes Telescope. Other virtual labs are also presented } \\
\text { (radio antenas). }\end{array}$ \\
\hline $\begin{array}{l}\text { Learning } \\
\text { outcomes }\end{array}$ & $\begin{array}{l}\text { The main purpose this training was to promote the integration of remote and } \\
\text { virtual labs in the classroom following curriculum guidelines. }\end{array}$ \\
\hline $\begin{array}{l}\text { Photos or other } \\
\text { relevant material }\end{array}$ & http://nuclio.org/blog/o-universo-invisivel/ \\
\hline
\end{tabular}




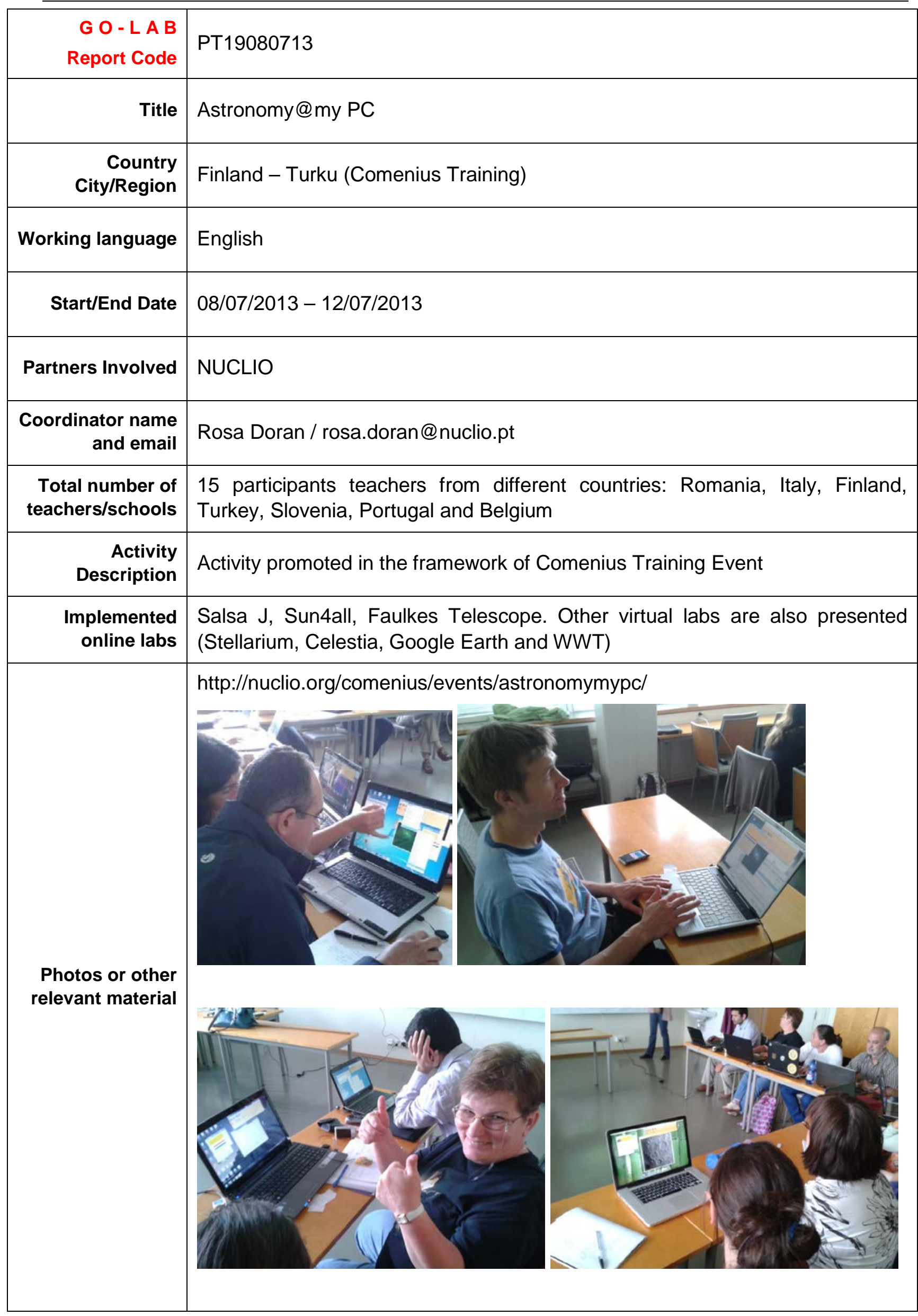




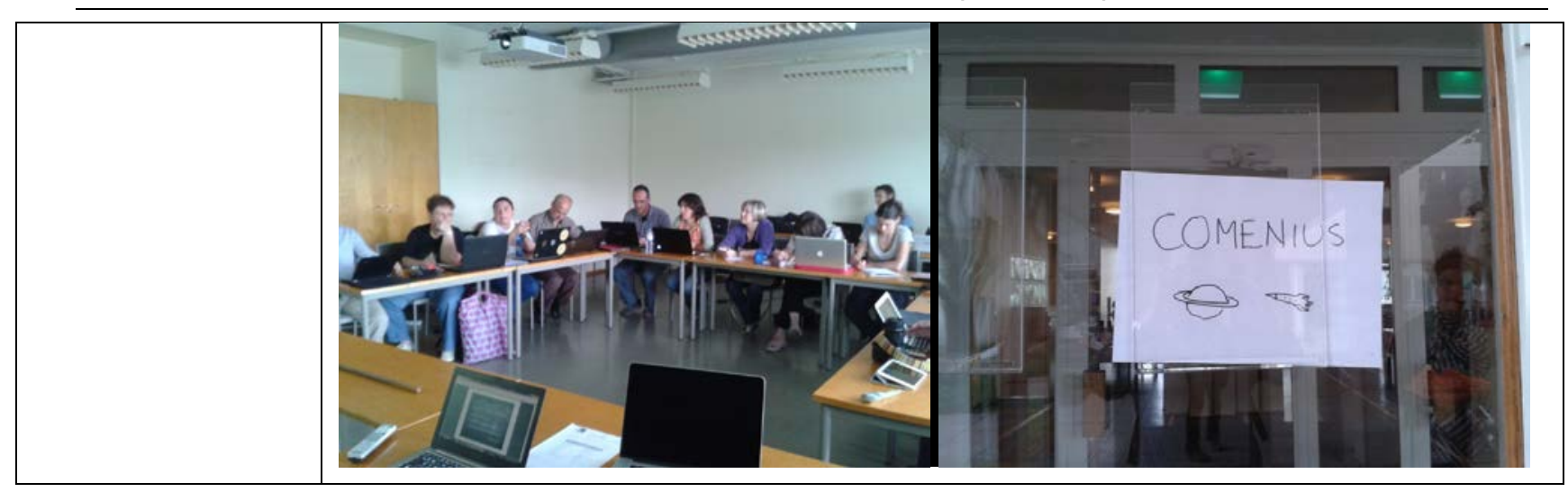




\begin{tabular}{|c|c|}
\hline $\begin{array}{r}\text { G O - L A B } \\
\text { Report Code }\end{array}$ & PT19290713 \\
\hline Title & Astronomy@my PC and Astronomy@my Backpack \\
\hline $\begin{array}{r}\text { Country } \\
\text { City/Region }\end{array}$ & Greece - Volos \\
\hline Working language & English \\
\hline Start/End Date & 29/07/2013 - 02/08/2013 \\
\hline Partners Involved & NUCLIO / EA \\
\hline $\begin{array}{r}\text { Coordinator name } \\
\text { and email }\end{array}$ & Rosa Doran / rosa.doran@nuclio.pt \\
\hline $\begin{array}{l}\text { Total number of } \\
\text { teachers/schools }\end{array}$ & $\begin{array}{l}15 \text { participants teachers from different countries: Portugal, Romenia, Poland, } \\
\text { Belgium, Srilanka, USA }\end{array}$ \\
\hline $\begin{array}{r}\text { Activity } \\
\text { Description }\end{array}$ & $\begin{array}{l}\text { Activity promoted in the framework of Comenius Training Event and the } \\
\text { Discover the Cosmos/ Global Hands-on Universe } 2013\end{array}$ \\
\hline $\begin{array}{r}\text { Implemented } \\
\text { online labs }\end{array}$ & $\begin{array}{l}\text { Salsa J, Sun4all, Faulkes Telescope. Other virtual labs are also presented } \\
\text { (Stellarium, Celestia, Google Earth and WWT) }\end{array}$ \\
\hline $\begin{array}{l}\text { Learning } \\
\text { outcomes }\end{array}$ & The theme of big ideas was briefly introduced \\
\hline $\begin{array}{l}\text { Photos or other } \\
\text { relevant material }\end{array}$ & $\begin{array}{l}\text { http://nuclio.org/comenius/events/astronomymypc-2/ } \\
\text { https://www.facebook.com/media/set/?set=a.689733594376991.1073741837.1 } \\
\text { 30639500286406\&type=3 }\end{array}$ \\
\hline
\end{tabular}




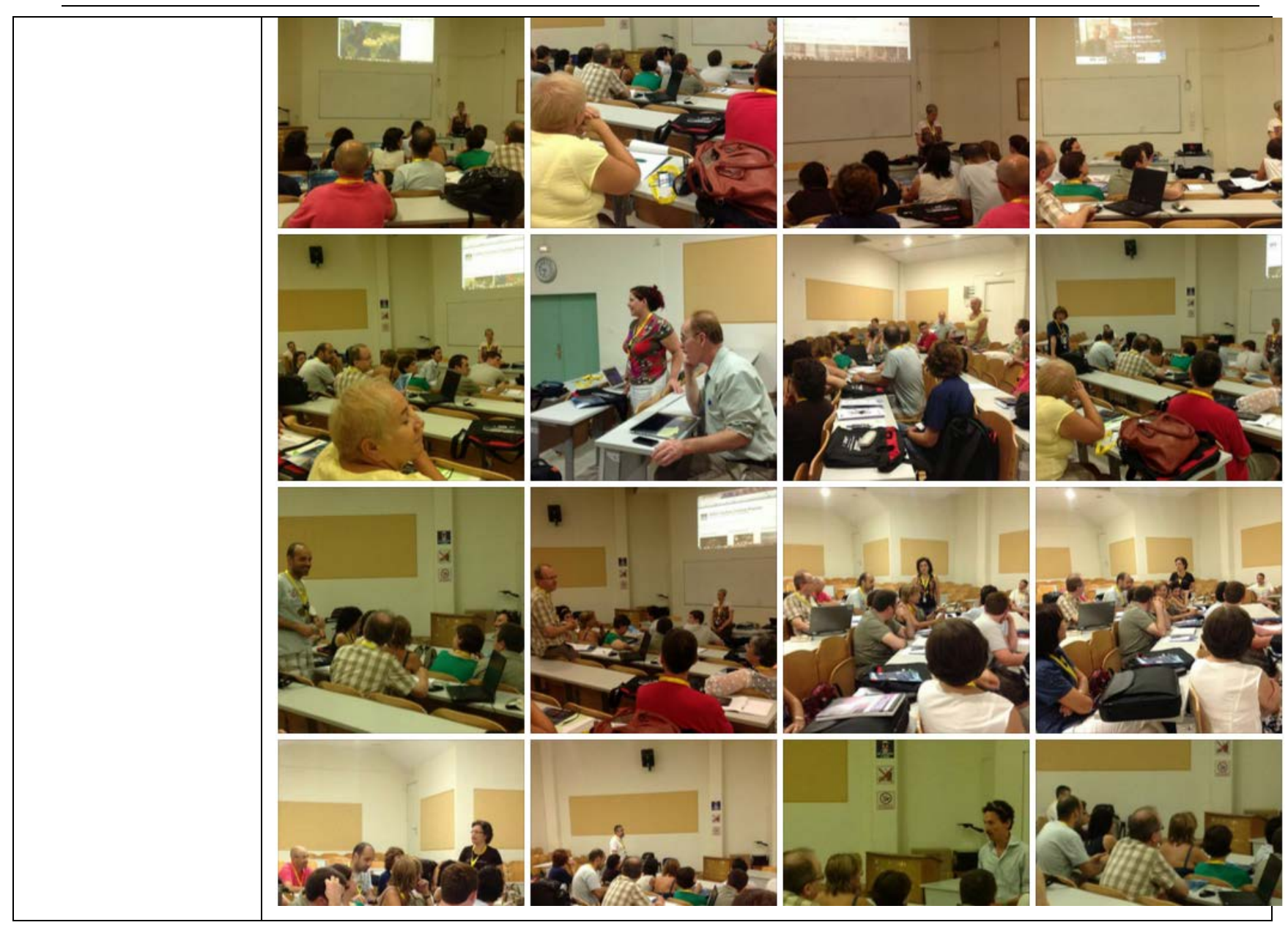




\begin{tabular}{|c|c|}
\hline $\begin{array}{r}\text { G O - L A B } \\
\text { Report Code }\end{array}$ & PT19161113 \\
\hline Title & Laboratórios Online para Astronomia (On-line labs for astronomy) \\
\hline $\begin{array}{r}\text { Country } \\
\text { City/Region }\end{array}$ & Portugal - Vila Nova de Gaia \\
\hline Working language & Portuguese \\
\hline Start/End Date & $16 / 11 / 2013$ \\
\hline Partners Involved & NUCLIO \\
\hline $\begin{array}{r}\text { Coordinator name } \\
\text { and email }\end{array}$ & Rosa Doran / rosa.doran@nuclio.pt \\
\hline $\begin{array}{l}\text { Total number of } \\
\text { teachers/schools }\end{array}$ & 13 participantes (Mathematics, Natural Sciences and Physcis) \\
\hline $\begin{array}{r}\text { Activity } \\
\text { Description }\end{array}$ & $\begin{array}{l}\text { This is a certified training promoting the use of modern tools and resources for } \\
\text { science education specially designed for Go-lab. Several Go-lab tools are } \\
\text { presented. The Big Ideas were discussed, the construction of ILS and several } \\
\text { other research based projects presented and discussed. }\end{array}$ \\
\hline $\begin{array}{l}\text { Implemented } \\
\text { online labs }\end{array}$ & $\begin{array}{l}\text { Salsa J, Sun4all, Faulkes Telescope. Other virtual labs are also presented } \\
\text { (Stellarium, Celestia, Google Earth and WWT), Many cratered worlds. }\end{array}$ \\
\hline $\begin{array}{r}\text { Learning } \\
\text { outcomes }\end{array}$ & $\begin{array}{l}\text { The theme of big ideas was introduced and the tools and resources promoting } \\
\text { them presented. The main purpose of this part of the training is to promote the } \\
\text { interest of the teaches to collaborate between subject areas, grade levels and } \\
\text { and as far as possible using a contextualized approach }\end{array}$ \\
\hline $\begin{array}{l}\text { Photos or other } \\
\text { relevant material }\end{array}$ & 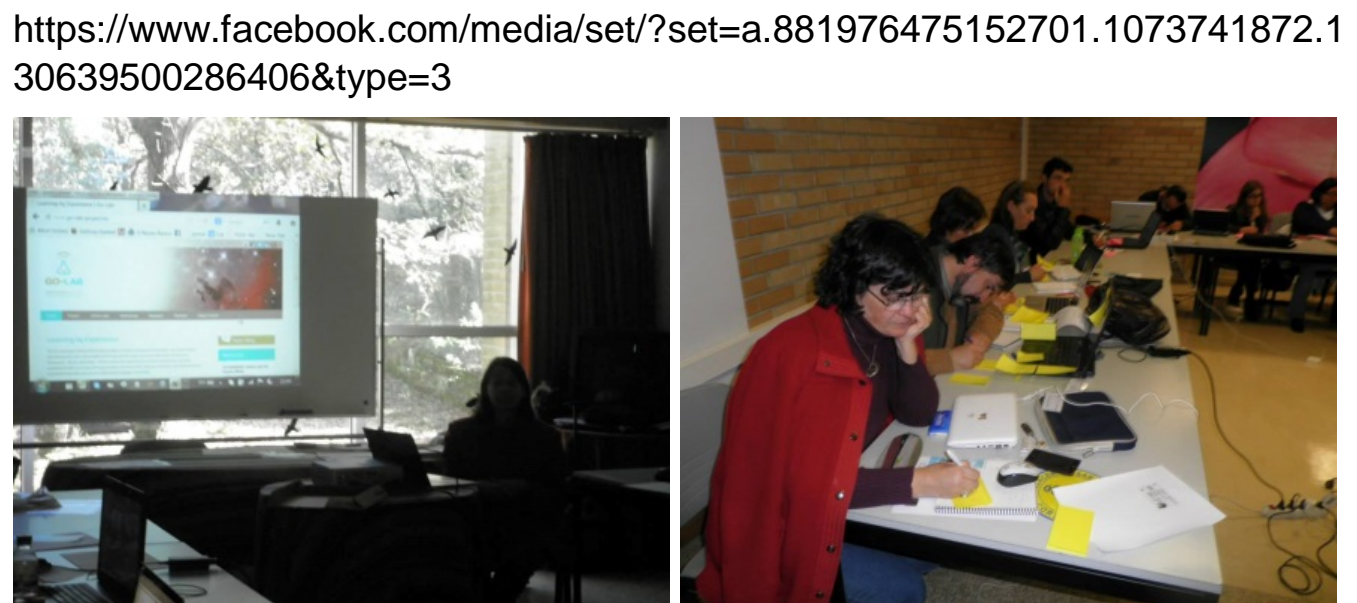 \\
\hline
\end{tabular}




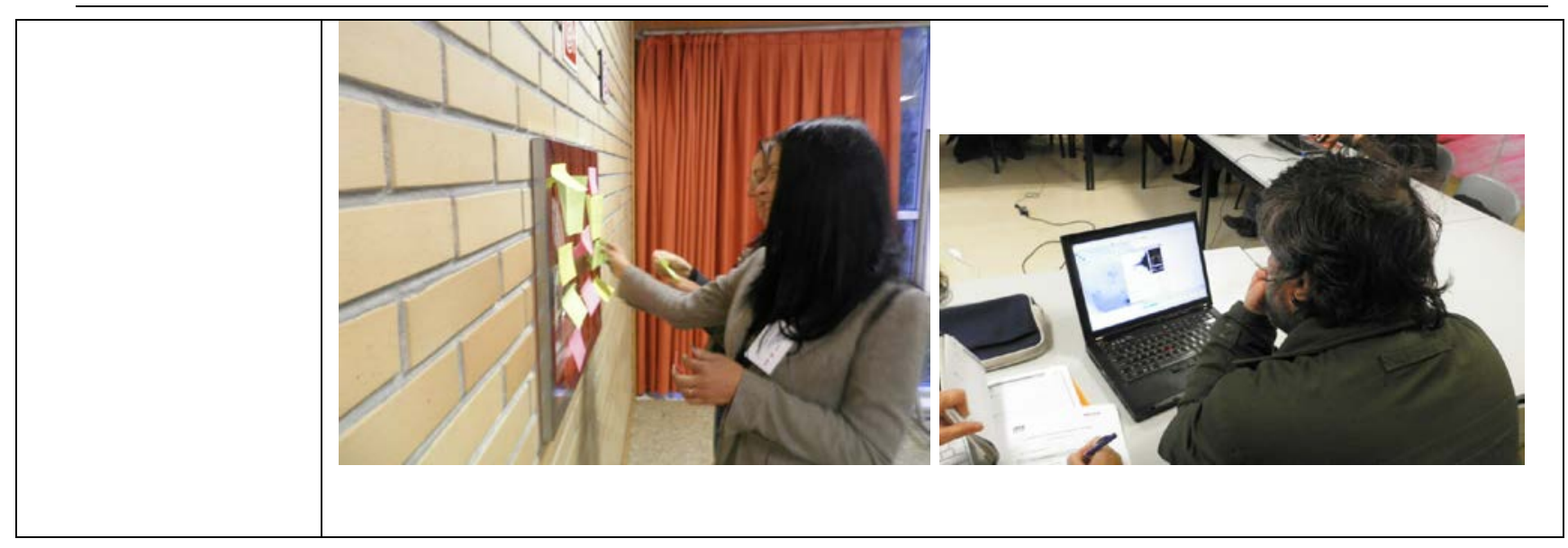




\subsection{Spain}

UDEUSTO is the national coordinator of implementation in Spain. It is also the lab provider/owner of remote labs such as Boole and Aquarium. During Phase-A it organised a national training workshop for science teachers with 49 participants. They practiced various virtual and remote labs including VISIR, Electricity, Boole, Methyl orange and associated ILSs for teaching physics, technology, chemistry etc.

\begin{tabular}{|c|c|}
\hline $\begin{array}{r}\text { G O - L A B } \\
\text { Report Code }\end{array}$ & ES12-25062014 \\
\hline Title & Go-Lab Inquiry Learning Space: ILS for Technology and Physics \\
\hline $\begin{array}{r}\text { Country } \\
\text { City/Region }\end{array}$ & Barcelona, Spain \\
\hline Working language & Spanish \\
\hline Start/End Date & 25/06/14 \\
\hline $\begin{array}{r}\text { Organizing } \\
\text { Institute }\end{array}$ & $\begin{array}{l}\text { University of Deusto; Cesire, Barcelona } \\
\text { (http://www.xtec.cat/web/innovacio/cesire) }\end{array}$ \\
\hline $\begin{array}{r}\text { Coordinator name } \\
\text { and email }\end{array}$ & Javier García-Zubía - zubia@deusto.es \\
\hline Activity Form & Workshop \\
\hline Activity Type & National activity \\
\hline $\begin{array}{r}\text { Total number of } \\
\text { teachers/schools }\end{array}$ & 49 teachers of secondary and high schools \\
\hline $\begin{array}{l}\text { Implemented } \\
\text { online labs }\end{array}$ & $\begin{array}{l}\text { Electricity Virtual Lab } \\
\text { VISIR remote lab for analog electronics and physics } \\
\text { Boole-Deusto experiments in frame of WebLab-Deusto remote lab for digital } \\
\text { electronics and technology } \\
\text { Archimedes; and Methyl orange }\end{array}$ \\
\hline Brief description & $\begin{array}{l}\text { Two weeks before the workshops, participated teachers got two examples of } \\
\text { ILSs. One is already integrated on the Go-Lab Portal ("From the gate level to } \\
\text { the digital circuit") and other one is in Word doc format ("Resistor Story"). } \\
\text { The duration of the workshop was } 3 \text { hours. } 53 \text { teachers were enrolled and } 49 \\
\text { participated in the workshop, around } 35 \text { provide the feedback over } \\
\text { questionnaire. } \\
\text { The workshop was divided in three parts: } \\
\text { Description of the Go-Lab project: goals, web sites, contest and } \\
\text { implementation. }\end{array}$ \\
\hline
\end{tabular}




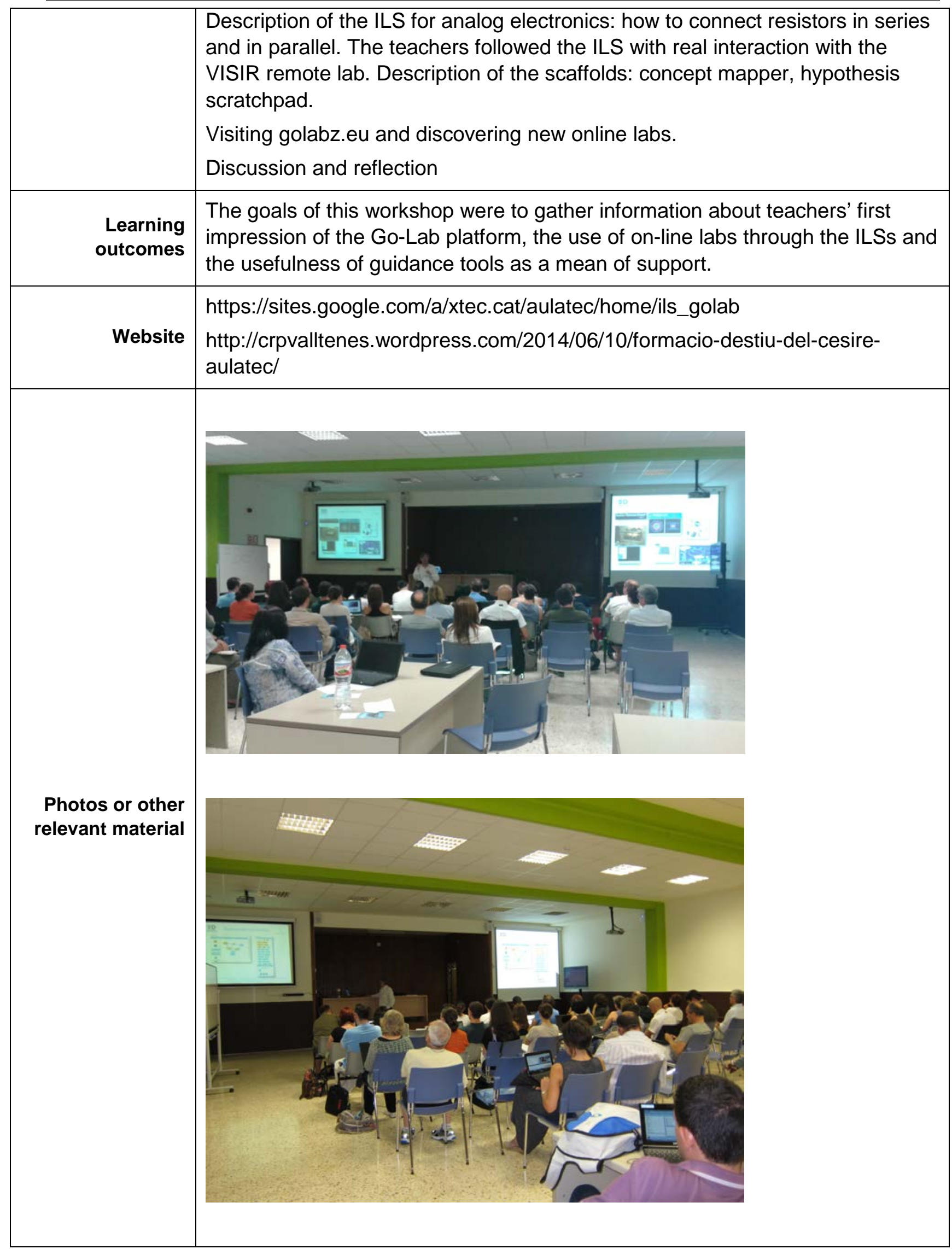




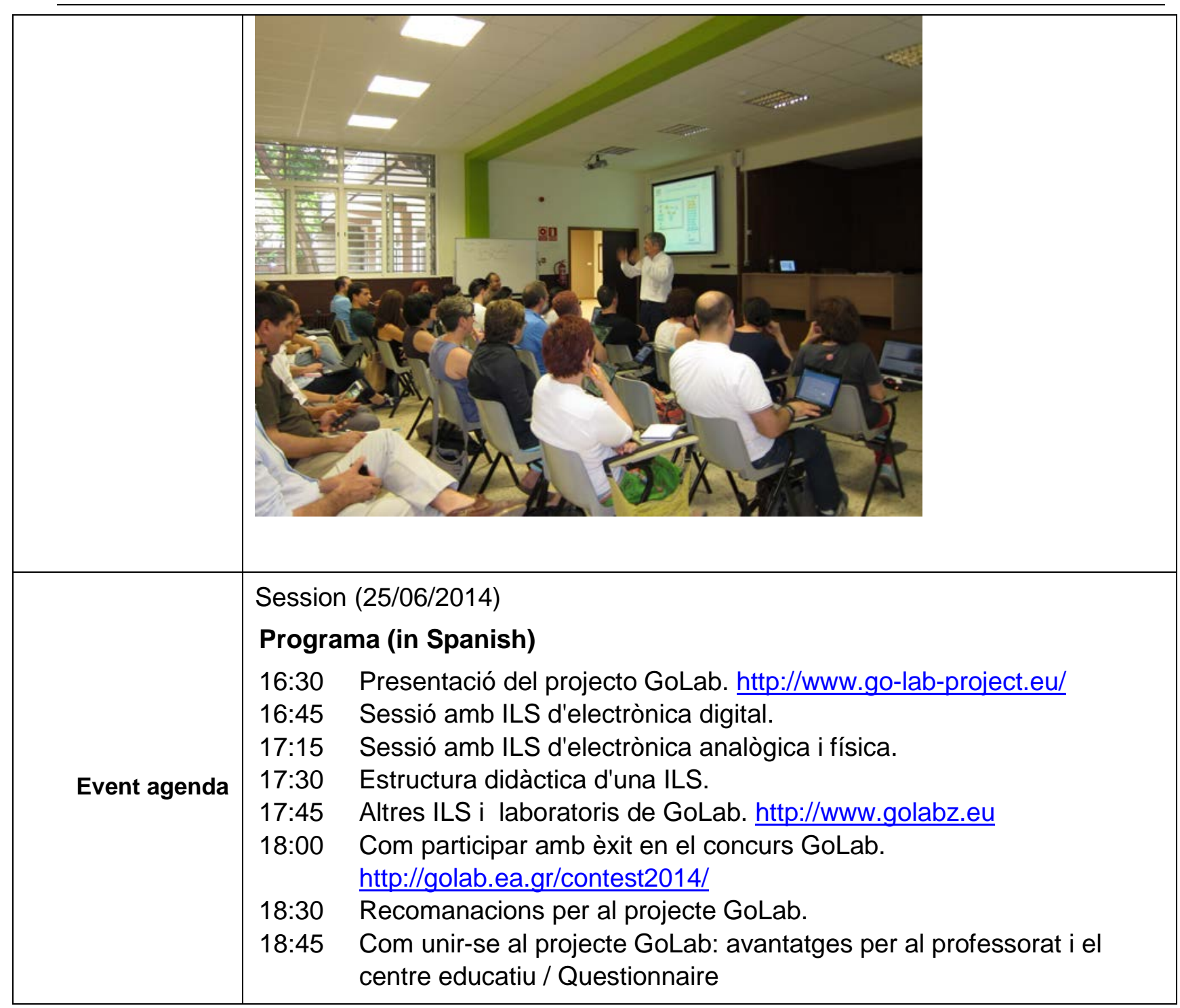




\subsection{UK}

UOG is the national coordinator of implementation in UK and provider of Faulkes Telescope remote lab. During Phase-A, school year 2013-2014, the educational community in UK were in a state of disturbance and dissatisfaction due to governmental reforms. As a consequence science teachers and schools in general were not motivated in participating in extra-curricular or other in-school activities outside their regular schedules. UOG devoted significant effort participating and contributing in activities organised by other partners focusing on physics and astronomy. In collaboration with ESA they conducted training for 30 science teachers from around Europe where the use of online labs was introduced and practiced (see first report below). UOG also attended and participated actively in various science and technology related events in the UK addressed to educational communities, stakeholders and public.

All reports of UOG's activities are included below. 


\begin{tabular}{|c|c|}
\hline $\begin{array}{r}\text { G O - L A B } \\
\text { Report Code }\end{array}$ & UK17-21/07/2014 \\
\hline Title & ESTEC ESA Summer Teacher Training Workshop \\
\hline $\begin{array}{r}\text { Country/City/Regi } \\
\text { on }\end{array}$ & ESTEC, Netherlands \\
\hline Working language & English \\
\hline Start/End Date & $21-25 / 07 / 2014$ \\
\hline $\begin{array}{r}\text { Organizing } \\
\text { Institute }\end{array}$ & ESA \\
\hline $\begin{array}{r}\text { Coordinator name } \\
\text { and email }\end{array}$ & Rebecca Barnes sciedu@esa.int \\
\hline $\begin{array}{r}\text { Activity } \\
\text { description }\end{array}$ & Workshop \\
\hline Activity Type & International \\
\hline $\begin{array}{r}\text { Total number of } \\
\text { teachers and } \\
\text { schools }\end{array}$ & 30 \\
\hline $\begin{array}{l}\text { Implemented } \\
\text { online labs }\end{array}$ & Faulkes Telescope, SalsaJ, Craters etc \\
\hline Brief description & $\begin{array}{l}\text { An ESA organised summer workshop for secondary school teachers of STEM } \\
\text { subjects. Participants were presented with innovative ways in which space and } \\
\text { astronomy can be used to teach STEM. Participants were informed about ESA } \\
\text { Education activities and resources, as well as current ESA missions, such as, } \\
\text { Rosetta and the Automated Transfer Vehicle (ATV) which transports cargo to } \\
\text { the International Space Station. }\end{array}$ \\
\hline Website & $\begin{array}{l}\text { http://www.esa.int/Education/Teachers_Corner/ESA_Summer_Workshop_for_ } \\
\text { Teachers_2014 }\end{array}$ \\
\hline
\end{tabular}




\begin{tabular}{|c|c|}
\hline $\begin{array}{r}\text { G O - L A B } \\
\text { Report Code }\end{array}$ & UK17-11/01/14 \\
\hline Title & Stargazing Live \\
\hline $\begin{array}{r}\text { Country/City/Regi } \\
\text { on }\end{array}$ & UK Nationwide \\
\hline Working language & English \\
\hline Start/End Date & 07/01/2014 - 11/01/2014 \\
\hline $\begin{array}{r}\text { Organizing } \\
\text { Institute }\end{array}$ & BBC \\
\hline $\begin{array}{r}\text { Coordinator name } \\
\text { and email }\end{array}$ & UOG \\
\hline $\begin{array}{r}\text { Activity } \\
\text { description }\end{array}$ & Public event at National Museum, Cardiff \\
\hline Activity Type & A local event as part of a series of national events \\
\hline $\begin{array}{r}\text { Total number of } \\
\text { teachers and } \\
\text { schools }\end{array}$ & Approx 1000 members of public \\
\hline $\begin{array}{l}\text { Implemented } \\
\text { online labs }\end{array}$ & Faulkes Telescope, SalsaJ, Craters etc \\
\hline Brief description & $\begin{array}{l}\text { Staff (including Paul Roche and Fraser Lewis) and students of USW attended a } \\
\text { stand as part of this astronomy-themed day-long public event. }\end{array}$ \\
\hline Website & $\begin{array}{l}\text { http://www.bbc.co.uk/programmes/articles/5TdSYVZCzSp1JDVCXgfdpVq/even } \\
\text { ts-2014 }\end{array}$ \\
\hline
\end{tabular}




\begin{tabular}{|c|c|}
\hline $\begin{array}{r}\text { G O - L A B } \\
\text { Report Code }\end{array}$ & UK17-25/02/14 \\
\hline Title & Inspiring Young People with Science - Telescopes for Schools \\
\hline $\begin{array}{r}\text { Country/City/Regi } \\
\text { on }\end{array}$ & House of Commons, London \\
\hline Working language & English \\
\hline Start/End Date & $25 / 02 / 2014$ \\
\hline $\begin{array}{r}\text { Organizing } \\
\text { Institute }\end{array}$ & Science and Technology Facilties Council (STFC) \\
\hline $\begin{array}{r}\text { Coordinator name } \\
\text { and email }\end{array}$ & UOG \\
\hline $\begin{array}{r}\text { Activity } \\
\text { description }\end{array}$ & $\begin{array}{l}\text { An event designed to showcase the work being done by robotic telescope } \\
\text { facilities and the students/schools that ese them }\end{array}$ \\
\hline Activity Type & National \\
\hline $\begin{array}{r}\text { Total number of } \\
\text { teachers and } \\
\text { schools }\end{array}$ & $\begin{array}{l}200 \text { people including MPs, industry representatives and teachers and pupils } \\
\text { from } \sim 5 \text { schools }\end{array}$ \\
\hline $\begin{array}{r}\text { Implemented } \\
\text { online labs }\end{array}$ & Faulkes Telescope, SalsaJ, Craters etc \\
\hline Brief description & $\begin{array}{l}\text { This event brought together representatives from the Faulkes Telescope } \\
\text { Project, the Liverpool Telescope and the Bradford Robotic Telescope to } \\
\text { celebrate their achievements in STEM-related subjects. It was held at the } \\
\text { House of Commons and included members of both Houses of Parliament, as } \\
\text { well as various education bodies such as the exam boards. Attended by Fraser } \\
\text { Lewis on behalf of Faulkes Telescope Project. } \\
\text { It also allowed pupils to present their work to this audience. }\end{array}$ \\
\hline Website & \\
\hline
\end{tabular}




\begin{tabular}{|c|c|}
\hline $\begin{array}{r}\text { G O - L A B } \\
\text { Report Code }\end{array}$ & UK17-14/04/14 \\
\hline Title & Go-Lab/GTTP Teacher Training \\
\hline $\begin{array}{r}\text { Country/City/Regi } \\
\text { on }\end{array}$ & Enschede, Netherlands \\
\hline Working language & English \\
\hline Start/End Date & $14-15 / 04 / 2014$ \\
\hline $\begin{array}{r}\text { Organizing } \\
\text { Institute }\end{array}$ & Nuclio, University of Twente \\
\hline $\begin{array}{r}\text { Coordinator name } \\
\text { and email }\end{array}$ & Rosa Doran (Nuclio) rosa.doran@gmail.com \\
\hline $\begin{array}{r}\text { Activity } \\
\text { description }\end{array}$ & Workshop \\
\hline Activity Type & International \\
\hline $\begin{array}{r}\text { Total number of } \\
\text { teachers and } \\
\text { schools }\end{array}$ & 15 teachers \\
\hline $\begin{array}{l}\text { Implemented } \\
\text { online labs }\end{array}$ & Faulkes Telescope, SalsaJ, Craters etc \\
\hline \multirow[t]{2}{*}{ Brief description } & $\begin{array}{l}\text { My involvement (Fraser Lewis) was to present information and a series of IBSE } \\
\text { scenarios around the topic of black holes - these activities are currently being } \\
\text { developed by rosa and myself and will be integrated into Go-Lab soon. }\end{array}$ \\
\hline & $\begin{array}{l}\text { The event also features several workshop activities delivered by Rosa Doran } \\
\text { and a Skype link-up with Eleftheria Tsourlidaki. }\end{array}$ \\
\hline Website & http://nuclio.org/comenius/events/astronomy-online-labs-for-inquiry-minds/ \\
\hline
\end{tabular}




\begin{tabular}{|c|c|}
\hline $\begin{array}{r}\text { G O - L A B } \\
\text { Report Code }\end{array}$ & UK17-02/05/14 \\
\hline Title & Go-Lab/GTTP Teacher Training \\
\hline $\begin{array}{r}\text { Country/City/Regi } \\
\text { on }\end{array}$ & Estoril, Portugal \\
\hline Working language & English \\
\hline Start/End Date & 02-05/05/2014 \\
\hline $\begin{array}{r}\text { Organizing } \\
\text { Institute }\end{array}$ & Nuclio \\
\hline $\begin{array}{r}\text { Coordinator name } \\
\text { and email }\end{array}$ & Rosa Doran (Nuclio) rosa.doran@gmail.com \\
\hline $\begin{array}{r}\text { Activity } \\
\text { description }\end{array}$ & Workshop \\
\hline Activity Type & International \\
\hline $\begin{array}{r}\text { Total number of } \\
\text { teachers and } \\
\text { schools }\end{array}$ & 15 teachers \\
\hline $\begin{array}{l}\text { Implemented } \\
\text { online labs }\end{array}$ & Faulkes Telescope, SalsaJ, Craters etc \\
\hline Brief description & $\begin{array}{l}\text { My involvement (Fraser Lewis) was to present information and a series of IBSE } \\
\text { scenarios around the topic of asteroids, comets and impacts - some of these } \\
\text { activities are already integrated into Go-Lab and others will be available soon. }\end{array}$ \\
\hline Website & http://www.galileoteachers.org/ \\
\hline
\end{tabular}




\begin{tabular}{|c|c|}
\hline $\begin{array}{r}\text { G O - L A B } \\
\text { Report Code }\end{array}$ & UK17-23/06/14 \\
\hline Title & $\begin{array}{l}\text { Royal Astronomical Society (RAS), National Astronomy Meeting (NAM), } \\
\text { Portsmouth }\end{array}$ \\
\hline $\begin{array}{r}\text { Country/City/Regi } \\
\text { on }\end{array}$ & International event \\
\hline Working language & English \\
\hline Start/End Date & 23/06/2014 \\
\hline $\begin{array}{r}\text { Organizing } \\
\text { Institute }\end{array}$ & Royal Astronomical Society (RAS) \\
\hline $\begin{array}{r}\text { Coordinator name } \\
\text { and email }\end{array}$ & UOG \\
\hline $\begin{array}{r}\text { Activity } \\
\text { description }\end{array}$ & Conference \\
\hline Activity Type & $\begin{array}{l}\text { Talk entitled "Bringing Astronomy Research into the Classroom " in the } \\
\text { Education and Public Outreach session. }\end{array}$ \\
\hline $\begin{array}{r}\text { Total number of } \\
\text { teachers and } \\
\text { schools }\end{array}$ & 40 people - combination of research, outreach and teachers \\
\hline $\begin{array}{r}\text { Implemented } \\
\text { online labs }\end{array}$ & Faulkes Telescope, SalsaJ, Craters etc \\
\hline Brief description & $\begin{array}{l}\text { Presented by Fraser Lewis, this was a } 15 \text { minute talk on the development of } \\
\text { IBSE resources using real astronomical research data. }\end{array}$ \\
\hline Website & https://www.ras.org.uk/events-and-meetings/ras-meetings/nam2014 \\
\hline
\end{tabular}




\begin{tabular}{|c|c|}
\hline $\begin{array}{r}\text { G O - L A B } \\
\text { Report Code }\end{array}$ & UK17-14/05/14 \\
\hline Title & CEMAS Mobile Apps and Education \\
\hline $\begin{array}{r}\text { Country/City/Regi } \\
\text { on }\end{array}$ & Liberty Stadium, Swansea \\
\hline Working language & English \\
\hline Start/End Date & $14 / 05 / 2014$ \\
\hline $\begin{array}{r}\text { Organizing } \\
\text { Institute }\end{array}$ & CEMAS \\
\hline $\begin{array}{r}\text { Coordinator name } \\
\text { and email }\end{array}$ & cemasevents@southwales.ac.uk \\
\hline $\begin{array}{r}\text { Activity } \\
\text { description }\end{array}$ & Workshop \\
\hline Activity Type & National \\
\hline $\begin{array}{r}\text { Total number of } \\
\text { teachers and } \\
\text { schools }\end{array}$ & 60 people \\
\hline $\begin{array}{r}\text { Implemented } \\
\text { online labs }\end{array}$ & Impact Calculator \\
\hline Brief description & $\begin{array}{l}\text { This event aimed to stimulate Welsh businesses to develop apps for } \\
\text { educational purposes, and raise awareness of the existence of such apps and } \\
\text { how they are having a huge impact on teaching and learning. } \\
\text { FT resources based around the Impact Calculator (developed with Go-Lab } \\
\text { partner ESA) were demonstrated by Paul Roche. }\end{array}$ \\
\hline Website & http://www.liberty-stadium.com/events_venue_events_view.php?id=53 \\
\hline
\end{tabular}




\begin{tabular}{|c|c|}
\hline $\begin{array}{r}\text { G O - L A B } \\
\text { Report Code }\end{array}$ & UK17-01/07/14 \\
\hline Title & Royal Society Summer Exhibition \\
\hline $\begin{array}{r}\text { Country/City/Regi } \\
\text { on }\end{array}$ & London \\
\hline Working language & English \\
\hline Start/End Date & $30 / 6-4 / 7 / 14$ \\
\hline $\begin{array}{r}\text { Organizing } \\
\text { Institute }\end{array}$ & The Royal Society \\
\hline $\begin{array}{r}\text { Coordinator name } \\
\text { and email }\end{array}$ & UOG \\
\hline $\begin{array}{r}\text { Activity } \\
\text { description }\end{array}$ & Exhibition \\
\hline Activity Type & National Exhibition for Schools \\
\hline $\begin{array}{r}\text { Total number of } \\
\text { teachers and } \\
\text { schools }\end{array}$ & $\sim 1000$ \\
\hline $\begin{array}{r}\text { Implemented } \\
\text { online labs }\end{array}$ & Faulkes Telescope, SalsaJ, Craters etc \\
\hline Brief description & $\begin{array}{l}\text { In conjunction with members of the ESA Gaia mission team, Paul Roche and } \\
\text { Fraser Lewis attended this week-long exhibition on } 2 \text { separate days to display } \\
\text { FT/Go-Lab/Gaia resources. ESA is also a member of Go-Lab and the Gaia } \\
\text { mission is one that we intend to produce further resources upon. }\end{array}$ \\
\hline Website & $\begin{array}{l}\text { gaia.ac.uk } \\
\text { http://sse.royalsociety.org/2014 }\end{array}$ \\
\hline
\end{tabular}




\subsection{Switzerland}

CERN conducted and coordinated the implementation activities in Switzerland. As already mentioned in other sections of the document, CERN has a European/International status rather than a national one and so its target audience, in terms of teachers and pilot schools, are coming from European countries in general and not only from the partner's host country. In this context it organized training activities for science teachers in the framework of its established High-school Teachers Training summer programme. The trainings comprised hands-on workshops with labs such as Cernland, LHCgame, Hypatia, Minerva, with a focus on particle physics research. In collaboration with partners EA and IASA teachers from Greece are supported further to implement them in their schools upon return.

\begin{tabular}{|c|c|}
\hline $\begin{array}{r}\text { G O - L A B } \\
\text { Report Code }\end{array}$ & $\mathrm{CH} 15-12 / 08 / 2014$ \\
\hline Title & HST2014, High-school Teachers Training Programme \\
\hline $\begin{array}{r}\text { Country/City/Regi } \\
\text { on }\end{array}$ & Switzerland, CERN, Geneva \\
\hline Working language & English \\
\hline Start/End Date & $12 / 8-15 / 8 / 2014$ \\
\hline $\begin{array}{l}\text { Organizing } \\
\text { Institute }\end{array}$ & CERN \\
\hline $\begin{array}{r}\text { Coordinator name } \\
\text { and email }\end{array}$ & Angelos Alexopoulos \\
\hline $\begin{array}{r}\text { Activity } \\
\text { description }\end{array}$ & Teacher Training \\
\hline Activity Type & International \\
\hline $\begin{array}{r}\text { Total number of } \\
\text { teachers and } \\
\text { schools }\end{array}$ & 38 \\
\hline $\begin{array}{r}\text { Implemented } \\
\text { online labs }\end{array}$ & Cernland, LHCgame, Hypatia, Minerva \\
\hline Brief description & $\begin{array}{l}\text { Introduced participants into methodologies, tools and activities through which } \\
\text { Physics, Particle Physics and CERN may be introduced effectively into the } \\
\text { school classroom and school lab. The Go-Lab Project, the Go-Lab Portal and } \\
\text { its associated Physics Labs (e.g. HYPATIA) were presented to the participants. } \\
\text { Dissemination material (e.g. leaflets and brochures) were also distributed to the } \\
\text { participants. }\end{array}$ \\
\hline Website & $\begin{array}{l}\text { Programme available at https://indico.cern.ch/event/331514/other- } \\
\text { view?view=standard }\end{array}$ \\
\hline
\end{tabular}




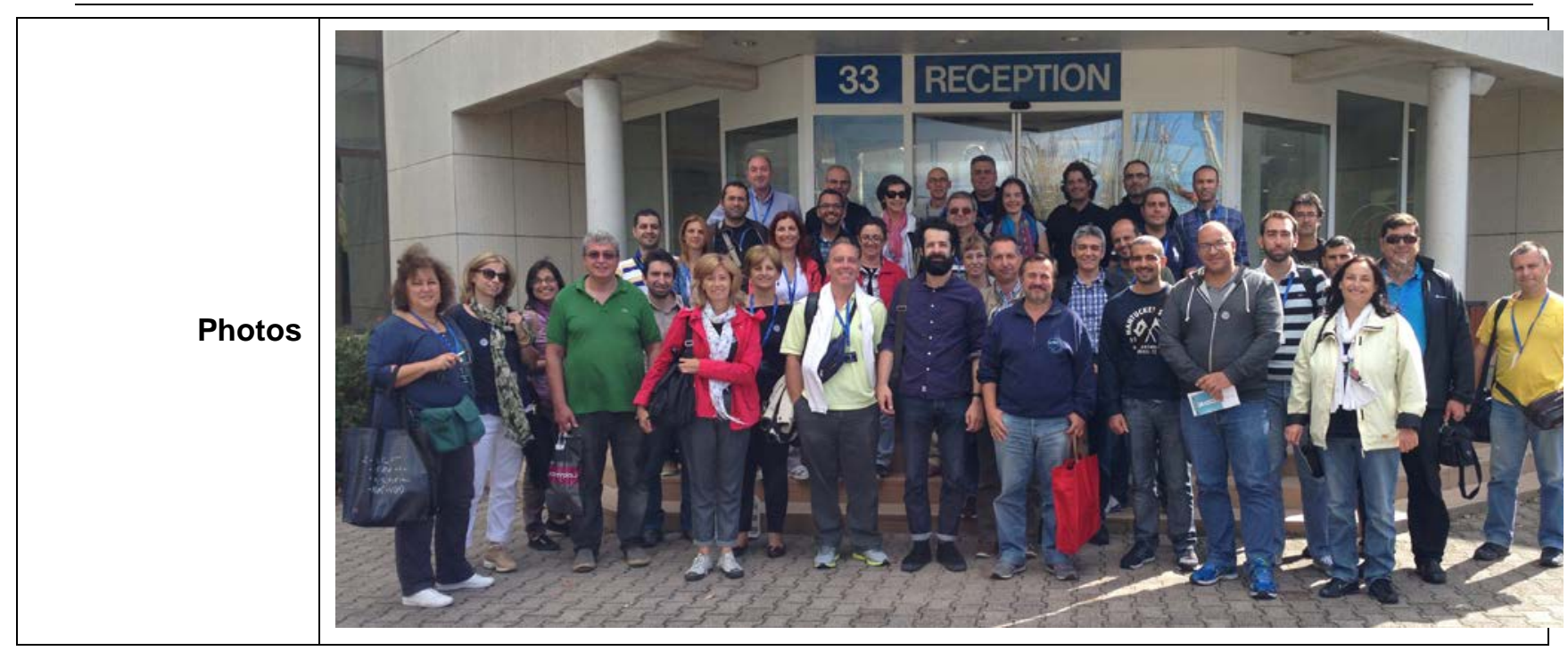




\section{Summary of results}

Implementation Phase-A covered the period from project month 16 to month 21, which corresponds to 1 Feb 2014 - 31 Jul 2014. During that 6-month period partners organized and conducted 35 implementation activities around the host countries. Of which, 17 were activities with students (with 560 participants) and 18 training of teachers (with 380 participants). In total 381 secondary schools were involved in these activities (344 schools in teacher trainings and 37 in in-classroom activities with students). The full list of activities is tabulated below. Graphs 1 and 2 depict the distribution of number of participants in teacher trainings and activities with students, respectively, per partner host country. Graphs 3, 4 and 5 show the corresponding distributions in terms of number of schools involved.

The partners' focus for Phase-A was primary on offering and conducting comprehensive training for teachers covering the pedagogical and technical aspects of the Go-Lab approach. In this way they laid the foundations for successful implementation in Phase-B (which starts in project month 25 and lasts until month 33, 1 Nov 2014 - 31 Jul 2014) when an upgraded release of the system will be available (with updated and enriched repository of labs and authoring environment). The numbers reported herein are well exceeding the target set in DoW [1], i.e. implementation in 100 schools, and was necessary to be accommodated in order to satisfy the overwhelming interest and demand by schools to participate in the project (see also D7.1 and D7.2 [6],[7]).

In Phase-A and in the majority of the reported events, activities involved the use of online labs standalone. In some cases there were implementations of existing or already developed Inquiry Learning Spaces with minimum authoring by teachers. The online labs that partners demonstrated and introduced to schools were the following (listed alphabetically per category): Simulations/virtual labs: Cernland, Craters, Electricity lab, Fishbowl, Galaxy-crash, Geogebra, Impact calculator, LHCgame, Osmotic power, PhET, Radioactivity, Splash

Datasets: Hypatia, ESA-SOHO, iSpyCMS, Minerva, SalsaJ, Sun4all

Remote labs: Aquarium, Boole, Faulkes-Telescope, Methyl orange, VISIR

The activities were linked to various science curriculum domains and in particular to Physics, Astronomy, Technology, Biology, Ecology, Maths, and Chemistry. Their classification in terms of subject domain is shown in Graphs 6 and 7, for teacher trainings and activities with students, respectively. The grand majority is on Physics and Astronomy. This fact is explained by the expertise and experience of the partners involved, and the online labs available in the repository at the time. Since then the repository of labs has been updated and populated with more labs from a variety of subjects that will be utilized in Phase-B activities.

In conclusion, during the first phase of implementation partners organized series of training workshops for teachers and activities with students reaching a large number of schools across different countries. The science teachers that participated were in general very interested in the Go-Lab overall approach. The national coordinators and partners that organised or conducted these activities and closely interacted with the teachers and schools identified certain areas of concern or expectations of improvement that they expressed/recommended. Their general remarks are: 
- Science teachers find that inquiry-based teaching is beneficial however it is difficult to implement due to time and curriculum constraints. They suggest that if shorter example ILSs are offered in the repository then their use in everyday classroom schedule will be facilitated.

- If labs and support applications/scaffolds can be available in the native language of students then their uptake will be easier.

- Given the large number of schools and teachers a community support/tutoring platform is needed for the subsequent implementation phases $B$ and $C$.

- Teachers in general would like to have both an example at hand to follow and at the same time the flexibility to easily change, adapt and further develop it according to their specific needs, audience and experience. They are eager to practice the newer version of the system, which is expected to be released for project year 2, with the repository enriched with larger variety of labs and subject domains and accompanied by an authoring environment with upgraded functionality and user interface.

The next implementation Phase-B runs in the 9-month period from month 25, 1 Nov $2014-31$ Jul 2014. During this phase the pilot schools will use the system more extensively and at 3 levels, namely, use the Go-Lab repository of labs for searching; implement existing Inquiry Learning Spaces developed by the project teams; develop new or adapt existing Inquiry Learning Spaces. 


\begin{tabular}{|c|c|c|c|c|c|c|}
\hline Country & Partner(s) & Date(s) & Type & $\begin{array}{l}\text { Partici- } \\
\text { pants } \\
\text { (Schools) }\end{array}$ & Labs & Subject(s) \\
\hline Austria & CUAS & 03/04/2014 & $\begin{array}{l}\text { Training } \\
\text { of } \\
\text { teachers }\end{array}$ & $16(10)$ & Radioactivity, VISIR & $\begin{array}{l}\text { Physics, } \\
\text { Technology }\end{array}$ \\
\hline Austria & CUAS & 03/04/2014 & $\begin{array}{l}\text { Activity } \\
\text { with } \\
\text { students }\end{array}$ & $52(4)$ & Radioactivity, VISIR & $\begin{array}{l}\text { Physics, } \\
\text { Technology }\end{array}$ \\
\hline Austria & CUAS & 07/07/2014 & $\begin{array}{l}\text { Training } \\
\text { of } \\
\text { teachers }\end{array}$ & $6(6)$ & Radioactivity & Physics \\
\hline Belgium & EUN & $15 / 02 / 2014$ & $\begin{array}{l}\text { Training } \\
\text { of } \\
\text { teachers }\end{array}$ & $15(15)$ & $\begin{array}{l}\text { Hypatia, Galaxy- } \\
\text { crash }\end{array}$ & $\begin{array}{l}\text { Physics, } \\
\text { Astronomy }\end{array}$ \\
\hline $\begin{array}{l}\text { Belgium, } \\
\text { France }\end{array}$ & EUN & $02 / 03 / 2013$ & $\begin{array}{l}\text { Training } \\
\text { of } \\
\text { teachers }\end{array}$ & $28(20)$ & $\begin{array}{l}\text { Faulkes-Telescope, } \\
\text { Aquarium, Hypatia, } \\
\text { Sun4all, Cernland }\end{array}$ & $\begin{array}{l}\text { Physics, } \\
\text { Astronomy }\end{array}$ \\
\hline $\begin{array}{l}\text { Belgium, } \\
\text { Spain }\end{array}$ & EUN & $10 / 03 / 2013$ & $\begin{array}{l}\text { Training } \\
\text { of } \\
\text { teachers }\end{array}$ & $30(22)$ & $\begin{array}{l}\text { Faulkes-Telescope, } \\
\text { Aquarium, Hypatia, } \\
\text { Sun4all, Cernland }\end{array}$ & $\begin{array}{l}\text { Physics, } \\
\text { Astronomy }\end{array}$ \\
\hline Cyprus & UCY & & $\begin{array}{l}\text { Training } \\
\text { of } \\
\text { teachers }\end{array}$ & $2(2)$ & Electricity lab & Physics \\
\hline Estonia & UTE & & $\begin{array}{l}\text { Training } \\
\text { of } \\
\text { teachers }\end{array}$ & $4(2)$ & $\begin{array}{l}\text { Biology labs, } \\
\text { Fishbowl }\end{array}$ & $\begin{array}{l}\text { Biology, } \\
\text { Ecology }\end{array}$ \\
\hline Germany & UDE & & $\begin{array}{l}\text { Training } \\
\text { of } \\
\text { teachers }\end{array}$ & $2(2)$ & Osmotic power & $\begin{array}{l}\text { Chemistry, } \\
\text { Ecology }\end{array}$ \\
\hline Greece & EA & $\begin{array}{l}01 / 02 / 2014 \\
- \\
31 / 03 / 2014\end{array}$ & $\begin{array}{l}\text { Activity } \\
\text { with } \\
\text { students }\end{array}$ & $10(1)$ & Splash, PhET & Physics \\
\hline Greece & EA & $10 / 02 / 2014$ & $\begin{array}{l}\text { Activity } \\
\text { with } \\
\text { students }\end{array}$ & $20(1)$ & $\begin{array}{l}\text { ESA-SOHO } \\
\text { dataset, SalsaJ, } \\
\text { Geogebra }\end{array}$ & $\begin{array}{l}\text { Maths, } \\
\text { Physics, } \\
\text { Astronomy }\end{array}$ \\
\hline Greece & EA & $11 / 03 / 2014$ & $\begin{array}{l}\text { Activity } \\
\text { with } \\
\text { students }\end{array}$ & $28(1)$ & iSpyCMS & $\begin{array}{l}\text { Physics, } \\
\text { Technology }\end{array}$ \\
\hline Greece & EA & $\begin{array}{l}01 / 04 / 2014 \\
- \\
07 / 05 / 2014\end{array}$ & $\begin{array}{l}\text { Activity } \\
\text { with } \\
\text { students }\end{array}$ & $35(7)$ & Splash, PhET & Physics \\
\hline Greece & EA, IASA & $29 / 04 / 2014$ & $\begin{array}{l}\text { Training } \\
\text { of } \\
\text { teachers }\end{array}$ & $22(19)$ & Hypatia & Physics \\
\hline
\end{tabular}




\begin{tabular}{|c|c|c|c|c|c|c|}
\hline Country & Partner(s) & Date(s) & Type & $\begin{array}{l}\text { Partici- } \\
\text { pants } \\
\text { (Schools) }\end{array}$ & Labs & Subject(s) \\
\hline Greece & EA, IASA & $20 / 05 / 2014$ & $\begin{array}{l}\text { Training } \\
\text { of } \\
\text { teachers }\end{array}$ & $24(20)$ & Hypatia & Physics \\
\hline Greece & EA & 09/05/2014 & $\begin{array}{l}\text { Activity } \\
\text { with } \\
\text { students }\end{array}$ & $42(1)$ & iSpyCMS & $\begin{array}{l}\text { Physics, } \\
\text { Technology }\end{array}$ \\
\hline Greece & IASA & $24 / 01 / 2014$ & $\begin{array}{l}\text { Activity } \\
\text { with } \\
\text { students }\end{array}$ & $28(4)$ & Hypatia & Physics \\
\hline Greece & IASA & $19 / 02 / 2014$ & $\begin{array}{l}\text { Activity } \\
\text { with } \\
\text { students }\end{array}$ & $25(4)$ & Hypatia & Physics \\
\hline Greece & IASA & 04/02/2014 & $\begin{array}{l}\text { Activity } \\
\text { with } \\
\text { students }\end{array}$ & $45(5)$ & Hypatia & Physics \\
\hline Greece & IASA & $10 / 03 / 2014$ & $\begin{array}{l}\text { Activity } \\
\text { with } \\
\text { students }\end{array}$ & $45(5)$ & Hypatia & Physics \\
\hline Greece & $\begin{array}{l}\text { EA } \\
\text { (organizer) } \\
\text { and EPFL, } \\
\text { UOG, } \\
\text { NUCLIO, } \\
\text { UTE, ULEIC }\end{array}$ & $\begin{array}{l}13 / 07 / 2014 \\
-18 / 07 / 2014\end{array}$ & $\begin{array}{l}\text { Training } \\
\text { of } \\
\text { teachers }\end{array}$ & $39(38)$ & $\begin{array}{l}\text { Faulkes } \\
\text { Telescopes, } \\
\text { Crashing Galaxies, } \\
\text { SalsaJ, Craters, } \\
\text { Electricity lab, } \\
\text { Splash, HYPATIA }\end{array}$ & $\begin{array}{l}\text { Physics, } \\
\text { Technology, } \\
\text { Biology, } \\
\text { Ecology, } \\
\text { Astronomy }\end{array}$ \\
\hline Netherlands & UT & $\begin{array}{l}24 / 03 / 2014 \\
25 / 03 / 2014\end{array}$ & $\begin{array}{l}\text { Activity } \\
\text { with } \\
\text { students }\end{array}$ & $27(1)$ & Splash & Physics \\
\hline Netherlands & UT & $\begin{array}{l}14 / 04 / 2014 \\
23 / 04 / 2014\end{array}$ & $\begin{array}{l}\text { Activity } \\
\text { with } \\
\text { students }\end{array}$ & $90(1)$ & Splash & Physics \\
\hline Netherlands & UT & $\begin{array}{l}15 / 05 / 2014 \\
28 / 05 / 2014\end{array}$ & $\begin{array}{l}\text { Activity } \\
\text { with } \\
\text { students }\end{array}$ & $60(1)$ & Splash & Physics \\
\hline Netherlands & UT & $\begin{array}{l}23 / 06 / 2014 \\
27 / 06 / 2014\end{array}$ & $\begin{array}{l}\text { Activity } \\
\text { with } \\
\text { students }\end{array}$ & $53(1)$ & Electricity lab & Physics \\
\hline Portugal & NUCLIO & 07/01/2014 & $\begin{array}{l}\text { Training } \\
\text { of } \\
\text { teachers }\end{array}$ & $20(20)$ & $\begin{array}{l}\text { Salsa J, Sun4all, } \\
\text { Faulkes Telescope }\end{array}$ & $\begin{array}{l}\text { Physics, } \\
\text { Astronomy }\end{array}$ \\
\hline Portugal & NUCLIO & $21 / 03 / 2014$ & $\begin{array}{l}\text { Training } \\
\text { of } \\
\text { teachers }\end{array}$ & $20(20)$ & $\begin{array}{l}\text { Salsa J, Sun4all, } \\
\text { Faulkes Telescope }\end{array}$ & $\begin{array}{l}\text { Physics, } \\
\text { Astronomy }\end{array}$ \\
\hline Portugal & NUCLIO & 04/05/2014 & $\begin{array}{l}\text { Training } \\
\text { of } \\
\text { teachers }\end{array}$ & $30(30)$ & $\begin{array}{l}\text { Salsa J, Impact } \\
\text { calculator }\end{array}$ & $\begin{array}{l}\text { Physics, } \\
\text { Astronomy }\end{array}$ \\
\hline
\end{tabular}




\begin{tabular}{|l|l|l|l|l|l|l|}
\hline Country & Partner(s) & Date(s) & Type & $\begin{array}{l}\text { Partici- } \\
\text { pants } \\
\text { (Schools) }\end{array}$ & Labs & Subject(s) \\
\hline Portugal & NUCLIO & $\begin{array}{l}22 / 05 / 2014 \\
- \\
30 / 06 / 2014\end{array}$ & $\begin{array}{l}\text { Training } \\
\text { of } \\
\text { teachers }\end{array}$ & $5(1)$ & $\begin{array}{l}\text { Salsa J, Faulkes } \\
\text { Telescope }\end{array}$ & $\begin{array}{l}\text { Physics, } \\
\text { Astronomy }\end{array}$ \\
\hline Spain & UDEUSTO & $25 / 06 / 2014$ & $\begin{array}{l}\text { Training } \\
\text { of } \\
\text { teachers }\end{array}$ & $49(49)$ & $\begin{array}{l}\text { Electricity lab, } \\
\text { VISIR, Boole, } \\
\text { Methyl orange }\end{array}$ & $\begin{array}{l}\text { Physics, } \\
\text { Technology, } \\
\text { Chemistry }\end{array}$ \\
\hline $\begin{array}{l}\text { UK, } \\
\text { Netherlands }\end{array}$ & UOG, ESA & $\begin{array}{l}21 / 07 / 2014 \\
- \\
25 / 07 / 2014\end{array}$ & $\begin{array}{l}\text { Training } \\
\text { of } \\
\text { teachers }\end{array}$ & $30(30)$ & $\begin{array}{l}\text { Faulkes Telescope, } \\
\text { SalsaJ, Craters }\end{array}$ & $\begin{array}{l}\text { Physics, } \\
\text { Astronomy }\end{array}$ \\
\hline Switzerland & CERN & $\begin{array}{l}12 / 08 / 2014 \\
- \\
15 / 08 / 2014\end{array}$ & $\begin{array}{l}\text { Training } \\
\text { of } \\
\text { teachers }\end{array}$ & $38(38)$ & $\begin{array}{l}\text { Cernland, } \\
\text { LHCgame, Hypatia, } \\
\text { Minerva }\end{array}$ & Physics \\
\hline
\end{tabular}




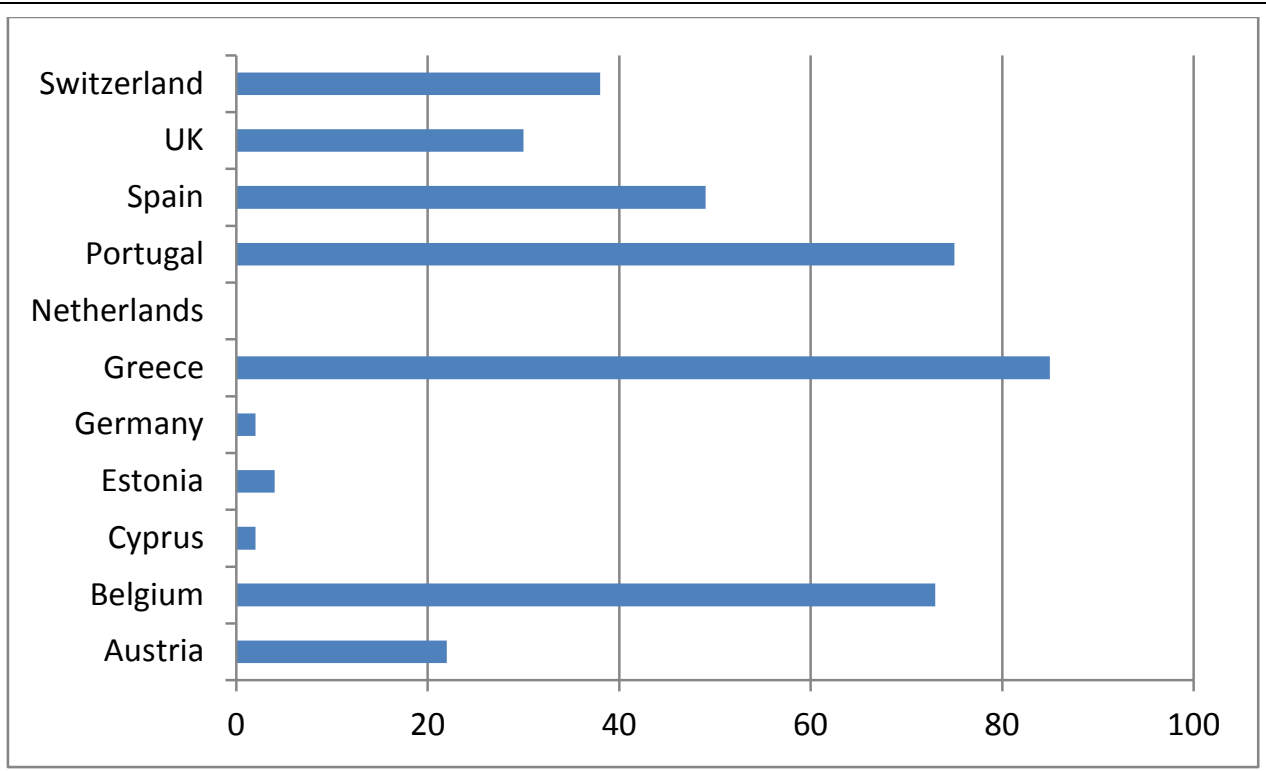

Graph 1. Number of participants in teacher trainings per partner host country

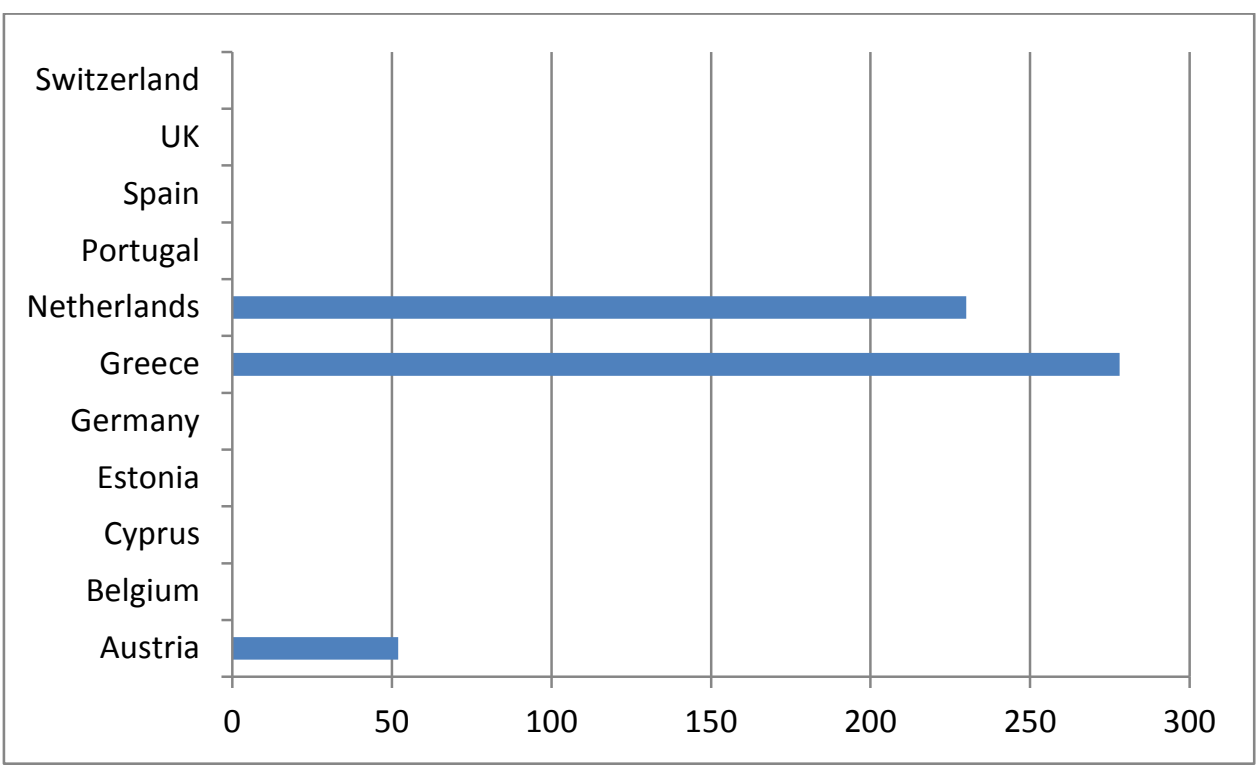

Graph 2. Number of participants in activities with students per partner host country 


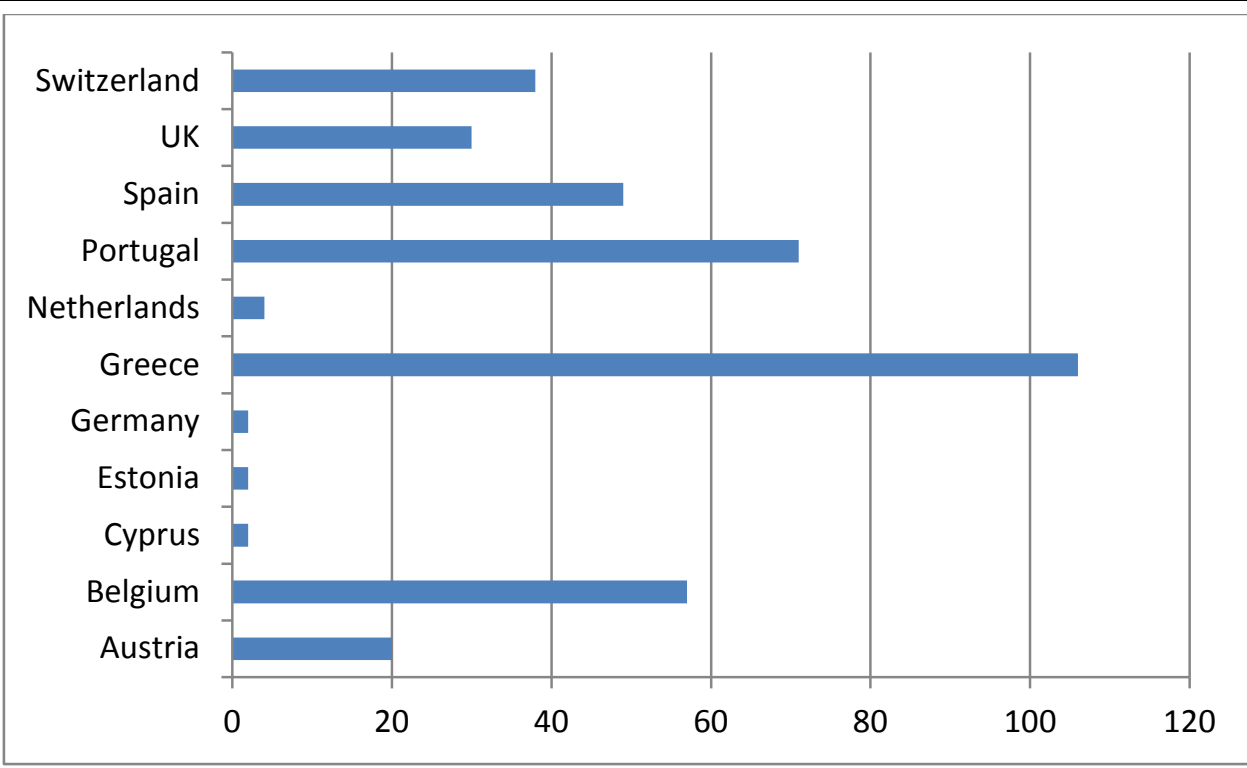

Graph 3. Number of schools involved in implementation activities (training of teachers or activities with students, or both) per partner host country

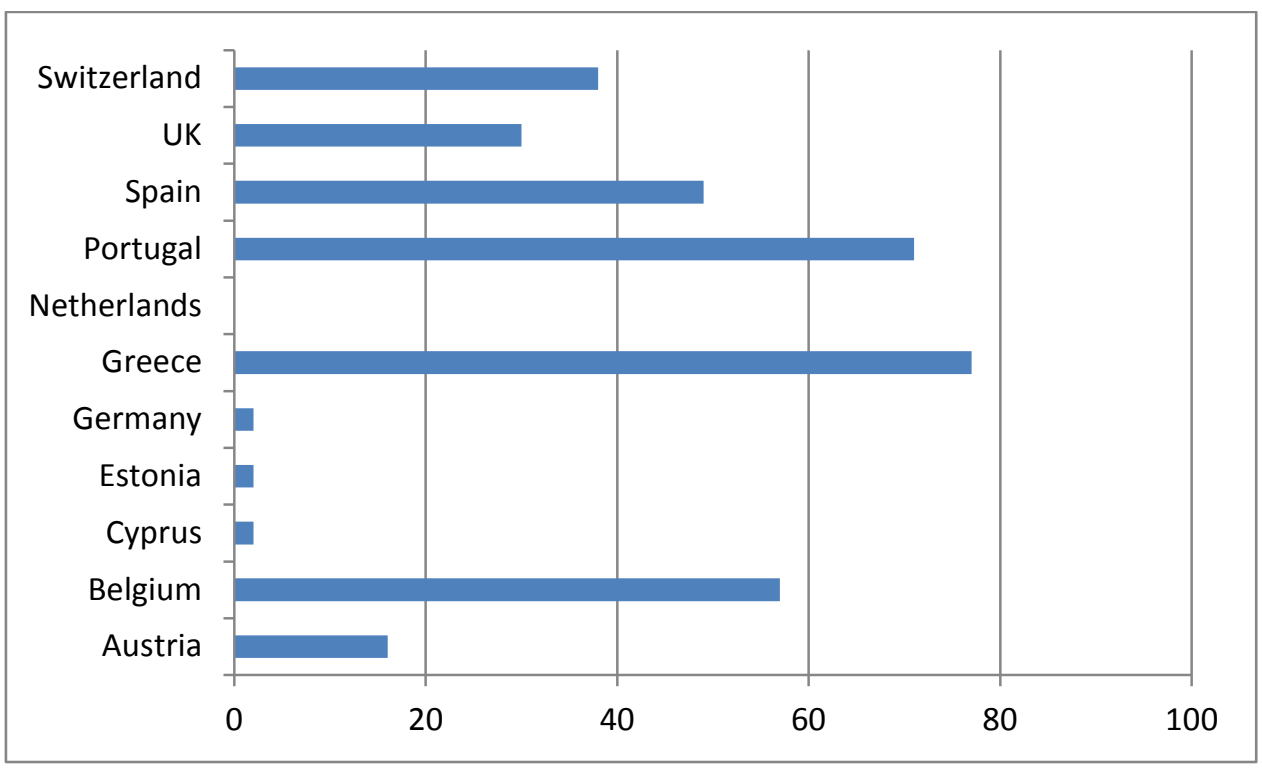

Graph 4. Number of schools involved in teacher trainings per partner host country 


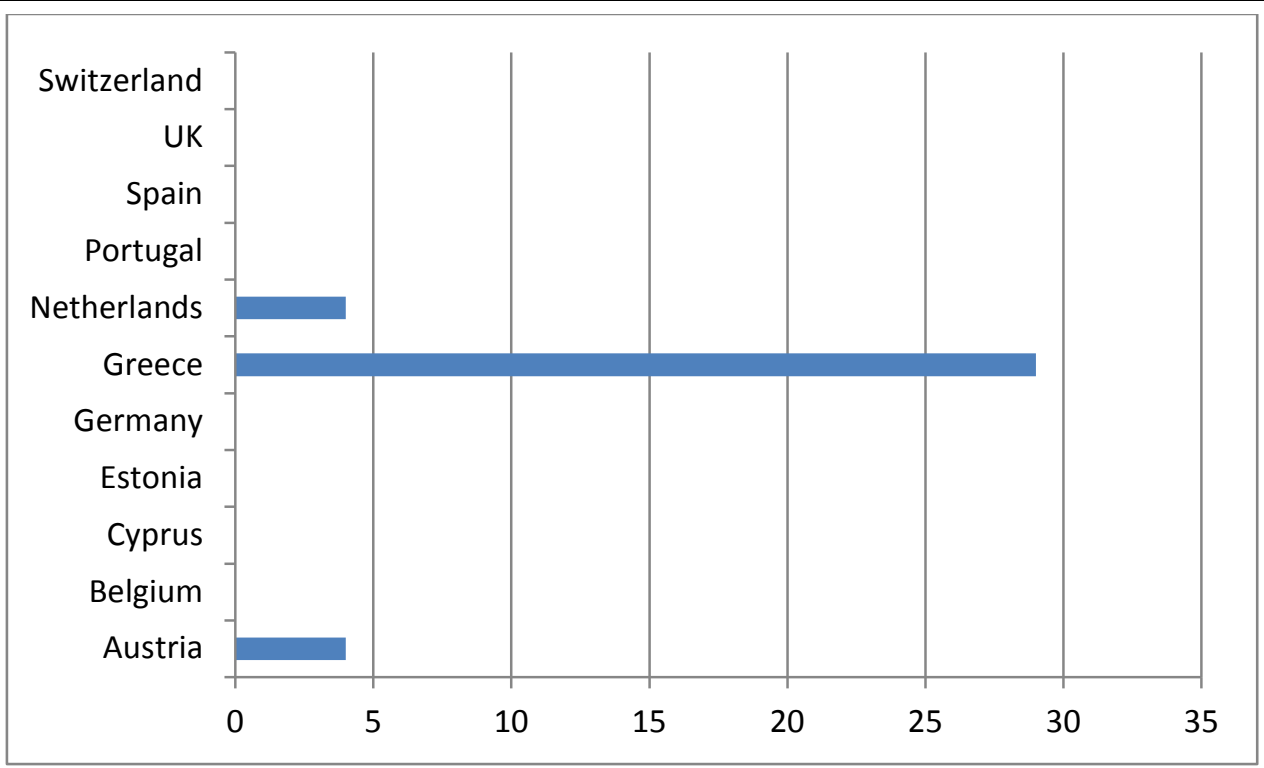

Graph 5. Number of schools involved in activities with students per partner host country

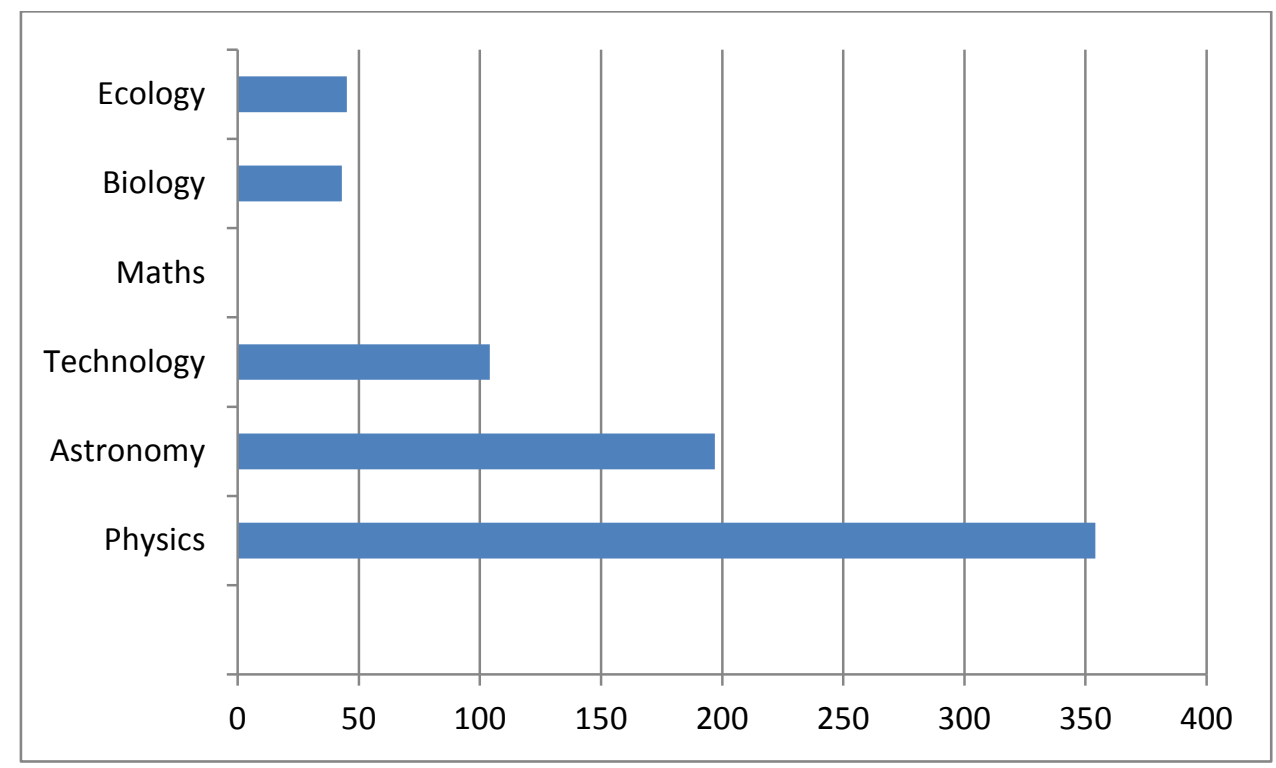

Graph 6. Number of participants in teacher trainings per subject domain 


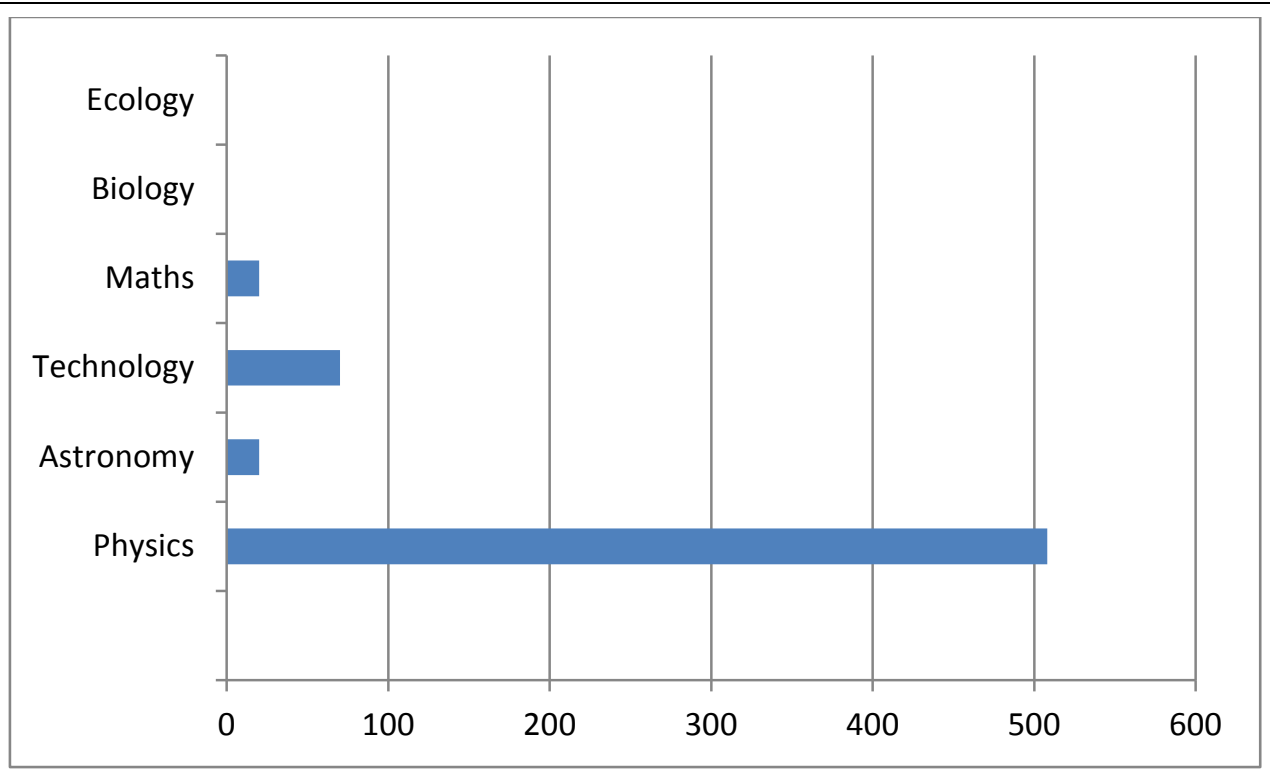

Graph 7. Number of participants in activities with students per subject domain 


\section{References}

[1] Go-Lab project Annex I - "Description of Work" version date 2012-09-19

[2] G. Mavromanolakis, Large-scale pilots (Work package 7), Go-Lab Kick-off meeting, 19-20 Nov 2012, Twente, the Netherlands, http://graasp.epfl.ch/\#item=asset_6607

[3] Go-Lab Deliverable 6.1 "Specifications of Participatory Activities", Month 3, Jan 2013

[4] Go-Lab "Communities Cluster" meeting, 12-13 Feb 2013, Bologna, Italy. Agenda, minutes and presentations can be found at http://graasp.epfl.ch/\#item=space_3213

[5] Go-Lab Deliverable 6.4 "Report on the participatory engagement activities", M24, Oct 2014

[6] Go-Lab Deliverable 7.1 "Pilot Sample Profile - V1", Month 18, Apr 2014

[7] Go-Lab Deliverable 7.2 "Pilot Sample Profile - V2", Month 24, Oct 2014 


\section{Appendix: Examples of event agendas}

\section{Summer School Programme}

Day 1:

- Introduction and overview of the course

- Participants' presentation

- Keynote Talks

- Lecture, 2 hours

\section{Day 2:}

- Introduction to learning technologies, eLearning tools, remote labs and virtual experiments. Presentation of example technology-enhanced educational activities. - How teachers can benefit.

- Lecture, 3 hours

- Presentation of educational repositories and federations of on-line labs.

- Workshop, 2 Hours

\section{Day 3:}

- Introduction to the use of educational resources as well as virtual and remote labs for science education within the school environment.

- Workshop, 2 Hours

- Learning design practice: Using the on-line labs and design of inquiry learning scenarios-Part1

- Workshop, 2 Hours

\section{Day 4:}

- Learning design practice: Using the on-line labs and design of inquiry learning scenarios-Part2 - Practice reflection: Discussion on the organization of on-line labs, connection to the science curricula.

- Workshop/Discussion, 3 hours

- Presentation of the added value of educational metadata and the importance of adding educational objectives. Characterization of learning scenarios using educational Metadata.

- Workshop, 2 hours

\section{Day 5:}

- Refining and finalizing the inquiry scenarios based on comments by the trainers.

- Workshop, 2 hours

- Participatory Engagement Activity: Reading and commenting on fellow participants' inquiry scenarios and exchange of opinions among participants.

- Discussion on the added value of teachers' on-line communities.

- Workshop, 2 hours

\section{Day 6:}

- Presentations of the inquiry scenarios produced by the participants.

- Lecture / Demonstration, 3 hours

- Conclusions - Evaluation of the training course - Guidelines for follow-up activities

- Lecture, 2 hours 
Agendas of short introductory and training events

Such events may be co-organized by partners with the local school counselor for a group of teachers from schools in the area. Also they may be accommodated within the framework of a conference or annual meeting of science teachers or similar event at national or regional level.

\section{Example agenda of a $2 \mathrm{~h} 30 \mathrm{~m}$ introductory event on Go-Lab.}

\begin{tabular}{|c|c|c|}
\hline \multicolumn{2}{|c|}{ Time } & Session description \\
\hline 9:00 & $-\quad 9: 45$ & Introduction and welcome (5 min) \\
\hline & & $\begin{array}{l}\text { Presentation of an educational scenario (e.g. on astronomy, physics or biology) by a } \\
\text { science teacher using online labs }\end{array}$ \\
\hline 9:45 & - $10: 00$ & Discussion \\
\hline 10:00 & $-10: 15$ & Break \\
\hline 10:15 & $-11: 00$ & $\begin{array}{l}\text { What Go-Lab offers (presentation of the pedagogical framework, objectives and the } \\
\text { federation of labs and tools) }\end{array}$ \\
\hline 11:00 & $-11: 15$ & Discussion \\
\hline 11:15 & $-11: 30$ & Feedback collection, recruitment of interested teachers \\
\hline
\end{tabular}

Example agenda of a $2 \mathrm{~h} 30 \mathrm{~m}$ training event/workshop on Go-Lab platform.

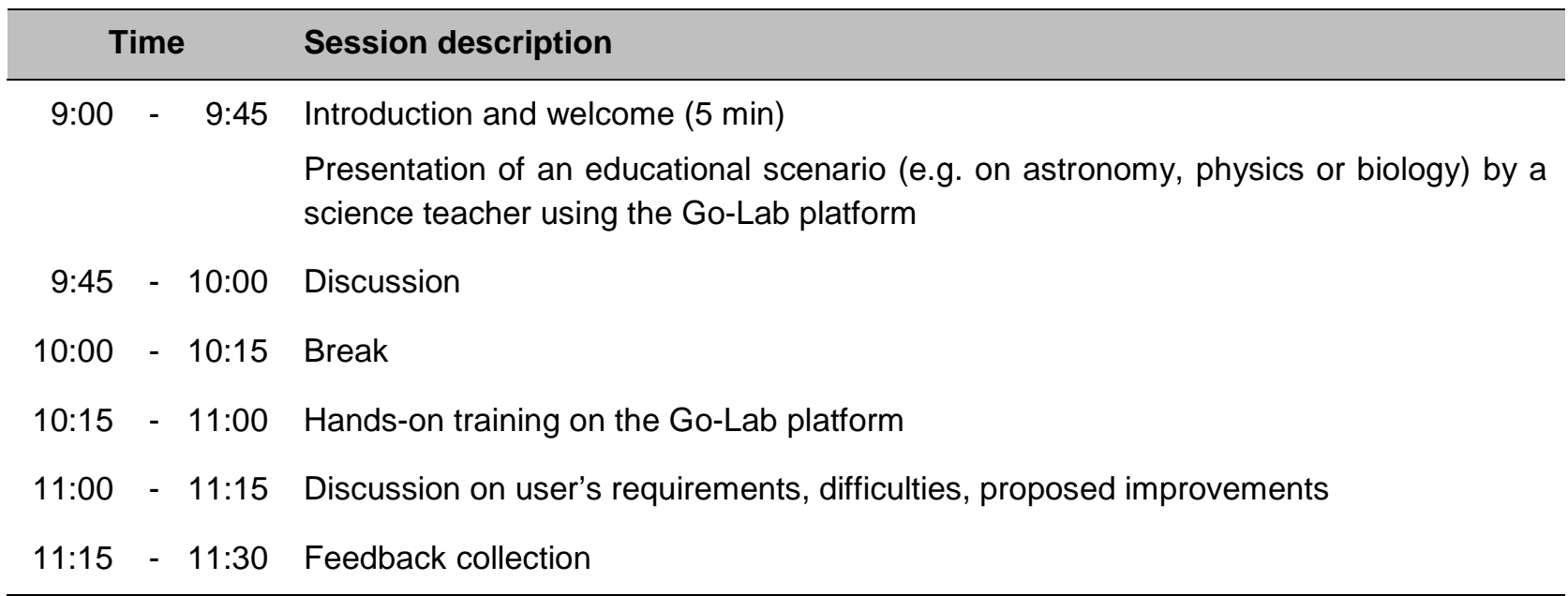




\section{Agenda of a training workshop}

Example agenda of a day long training workshop on Go-Lab platform and related educational scenarios.

\begin{tabular}{|c|c|c|c|c|}
\hline \multicolumn{4}{|c|}{ Time } & \multirow{2}{*}{$\begin{array}{l}\text { Session description } \\
\text { Introduction and welcome }\end{array}$} \\
\hline \multirow{7}{*}{ 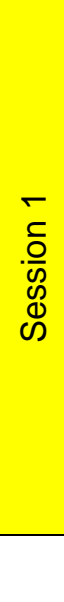 } & 9:00 & - & 9:15 & \\
\hline & 9:15 & - & $10: 15$ & $\begin{array}{l}\text { Presentation of educational scenario } 1 \text { (e.g. on astronomy, physics or } \\
\text { biology) by a science teacher using the Go-Lab platform }\end{array}$ \\
\hline & 10:15 & - & $10: 45$ & Discussion \\
\hline & $10: 45$ & - & $11: 00$ & Break \\
\hline & 11:00 & - & $12: 00$ & $\begin{array}{l}\text { Presentation of educational scenario } 2 \text { (e.g. on astronomy, physics or } \\
\text { biology) by a science teacher using the Go-Lab platform }\end{array}$ \\
\hline & 12:00 & - & $12: 30$ & Discussion \\
\hline & $12: 30$ & - & $13: 30$ & Lunch break \\
\hline \multirow{5}{*}{ 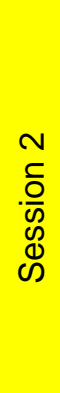 } & 13:30 & - & $15: 00$ & Hands-on training on the Go-Lab platform \\
\hline & $15: 00$ & - & $15: 15$ & Break \\
\hline & $15: 15$ & - & $16: 15$ & $\begin{array}{l}\text { Hands-on training on developing an educational scenario using the Go-Lab } \\
\text { platform }\end{array}$ \\
\hline & 16:15 & - & $16: 30$ & Discussion on user's requirements, difficulties, proposed improvements \\
\hline & $16: 30$ & - & $16: 45$ & Feedback collection (questionnaires) \\
\hline
\end{tabular}

